\title{
Double-headed nucleosides: Synthesis and applications
}

\author{
Vineet Verma ${ }^{1}$, Jyotirmoy Maity ${ }^{2}$, Vipin K. Maikhuri ${ }^{1}$, Ritika Sharma ${ }^{1}$, Himal K. Ganguly ${ }^{3}$ \\ and Ashok K. Prasad ${ }^{* 1}$
}

\author{
Review \\ Address: \\ ${ }^{1}$ Bioorganic Laboratory, Department of Chemistry, University of Delhi, \\ Delhi-110 007, India, 2Department of Chemistry, St. Stephen's \\ College, University of Delhi, Delhi-110 007, India and ${ }^{3}$ Department of \\ Biophysics, Bose Institute, P1/12 CIT Scheme VIIM, Kolkata-700 054 \\ India \\ Email: \\ Ashok K. Prasad* - ashokenzyme@gmail.com \\ * Corresponding author \\ Keywords: \\ acyclic double-headed nucleosides; bicyclic double-headed \\ nucleosides; furanosyl double-headed nucleosides; modified \\ nucleosides; pyranosyl double-headed nucleosides
}

Open Access

Open Access
heilstein J. Org. Chem. 2021, 17, 1392-1439.
Received: 27 January 2021
Accepted: 27 May 2021
Published: 08 June 2021
This article is part of the thematic issue "Celebrating the role of chemistry
in the success of oligonucleotides as therapeutics".
Guest Editors: P. Kumar and T. Brown
(C) 2021 Verma et al.; licensee Beilstein-Institut.
License and terms: see end of document.

\section{Abstract}

Double-headed nucleoside monomers have immense applications for studying secondary nucleic acid structures. They are also well-known as antimicrobial agents. This review article accounts for the synthetic methodologies and the biological applications of double-headed nucleosides.

\section{Introduction}

Nucleosides are the constructional subunits of deoxyribonucleic acids (DNA) or ribonucleic acids (RNA), which contain either a purine or pyrimidine nucleobase and a furanosyl moiety of pentose sugars, 2 -deoxyribose or ribose [1,2]. Nucleotides are constituted by addition of a phosphate group at the $5^{\prime}$-position of the nucleosides and these monomeric units polymerize to construct nucleic acids (DNA or RNA). These macromolecules preserve and express genetic information in all living cells and viruses. Modified nucleosides are a class of organic compounds which are unnatural and have an altered/substituted nucleobase and/or a modified pentose sugar $[3,4]$. The synthe- tic accessibility of these organic molecules encouraged researchers to prepare sugar-modified nucleosides [5,6] and nucleobase-modified nucleosides [7,8]. Modified nucleoside monomers comprising more than one nucleobase are called double-headed nucleosides $[9,10]$. A thorough literature search regarding double-headed nucleosides disclosed that these modified nucleosides were constituted with any two naturally occurring nucleobases, i.e., adenine, guanine, thymine, uracil, and cytosine $[9,10]$ or one naturally occurring nucleobase and one heterocyclic/carbocyclic moiety either attached directly to the sugar or via a linker. Further modifications were introduced by 
the substitution of some of the naturally occurring nucleobases by halogens or alkyl groups. On the other hand, a variety of heterocyclic/carbocyclic moieties were considered as the head of these modified nucleosides. The heterocyclic structures which were found to be attached to these double-headed nucleosides include triazolophthalazine [11], 4,6-di-tert-butylbenzoxazole [12], mesitylisoxazole [13], 5-trimethylsilyl-1,2,3-triazole [14], 1-pivaloyloxymethyl-1 $H$-1,2,3-triazole [15], 1,3,4-oxadiazino[6,5-b]indole [16], 6,7-dihydro-6-oxo-5H-1,2,4triazolo[3,4-b][1,3,4]thiadiazine [17], 1,2,4-triazino[5,6$b$ ]indole [18], 1,3,4-thiadiazoline [19], 1,3,4-oxadiazoline [19], 1,2,4-triazoline [19], 3-mercapto-1H-1,2,4-triazole [20], 1,3,4oxadiazole-2(3H)-thione [20], 4-amino-5-mercapto-4H-1,2,4triazole [20], and 1,2,4-triazolo[3,4-b](1,3,4)-thiadiazole moieties [21]. Additionally, selected examples of doubleheaded nucleosides comprising aromatic/polyaromatic/carbocyclic moieties such as phenyl [13-15,22], pyrene [23-25], adamant-1-yl [24], cholesteryl [24], perylen-3-yl [24], 4-(tertbutyldimethylsilyloxy/hydroxy)phenyl [26], 3/4-(N-((dimethylamino)methy-lidene)aminosulfonyl)phenyl [26,27], and sulfonamido-substituted benzothiazole [28] attached as an additional head are also reported in this review article. Literature data revealed that most of the double-headed nucleosides have the first nucleobase attached to the anomeric carbon of the pentofuranosyl/hexopyranosyl sugar moiety and an additional nucleobase/heterocyclic/carbocyclic moiety attached either directly or through a linker to any carbon of the sugar moiety either by $\mathrm{C}-\mathrm{N}$ or $\mathrm{C}-\mathrm{C}$ bonds. However, in case of base to base doubleheaded nucleosides, the additional nucleobase/substituent or unsubstituted phenyl moiety/polyaromatic moiety/carbocyclic moiety/heterocyclic moiety is attached to the first nucleobase with/without a linker. Whereas, all the acyclic double-headed nucleosides had natural nucleobases or heterocyclic moieties attached at the terminal carbons only.

Double-headed nucleosides are synthetically derived nucleoside scaffolds that are known to impact significantly secondary structures in nucleic acids [29]. Some oligonucleotides containing a particular double-headed nucleotide monomer have been found to form a three-way junction structure with a hairpin loop and two flanking sequences [30,31]. Moreover, these nucleotides have been found to orient the additional nucleobase towards the core of the duplex to participate in Watson-Crick base pairing [32-34]. The incorporation of the double-headed nucleosides into oligonucleotides followed by their duplex formation studies against complimentary oligonucleotide strands had described a very selective zipper-interaction [35], whereas a relative stabilization was observed due to stacking of these additional nucleobases across the minor groove [31]. The biological activity of the acyclic double-headed nucleosides was assessed through in vitro studies on Gram-positive bacteria
Staphylococcus aureus, Listeria inovanii and Gram-negative bacteria Klebsiella pneumoniae, Salmonella sp., and Escherichia coli [20]. Triazolyl double-headed nucleosides showed efficacy against eosinophil-derived neurotoxin, which is an eosinophil secretion protein and a member of the Ribonuclease A (RNase A) superfamily [36]. Double-headed nucleosides were also found to be active against orthopox viruses, vaccinia virus, and cowpox virus under in vitro conditions [11], whereas few double-headed nucleoside analogues showed a moderate cytostatic activity against human cervix carcinoma HeLa cells [37].

It is pertinent to mention that Sharma et al. [29] have reviewed the double-headed nucleotides in the recent past with a focus on their effects in nucleic acid duplexes and other secondary structures. Herein, we focused on the synthetic protocols used for accessing a variety of double-headed nucleoside monomers. Thus, this review is the comprehensive compilation of the synthetic protocols available for the production of double-headed nucleoside monomers and their applications. For better overview the review has been structured based on the types of the sugar moiety of the nucleoside and the position of the attachment of the additional base, either directly or through a linker on the sugar.

\section{Review}

\section{Furanosyl double-headed nucleosides}

Based on literature reports most of the double-headed nucleosides comprised a pentofuranosyl sugar moiety. Various synthetic methodologies have been developed for the introduction of the additional nucleobase/heterocyclic system directly or via a linker at the $\mathrm{C}-2^{\prime} / \mathrm{C}-3^{\prime} / \mathrm{C}-4^{\prime} / \mathrm{C}-5^{\prime}$ position of the pentofuranosyl moieties. We have categorized the double-headed furanosylnucleosides depending on the position of the attachment of the additional nucleobase/heterocyclic system at the particular carbon of the pentofuranosyl moiety of the nucleoside (Figure 1).

\section{1,2-Furanosyl double-headed nucleosides}

Herein, all nucleosides comprising furanosyl ring structures are included, with the first nucleobase attached to the $\mathrm{C}-1^{\prime}$ position and the second nucleobase introduced at the $\mathrm{C}-2^{\prime}$ position either with or without a linker (Figure 1).

Nielsen and co-workers [38,39] synthesized 2'-(pyrimidin-1yl)methyl- or 2'-(purin-9-yl)methyl-substituted double-headed nucleosides $\mathbf{4 a}-\mathbf{f}$ of arabinofuranosyluracil. The convergent synthesis of the double-headed nucleosides was achieved from uridine, which was first converted to the $3^{\prime}, 5^{\prime}$-(1,1,3,3-tetraisopropyldisiloxan-1,3-diyl)-protected (TIPDS) ketonucleoside $\mathbf{1}$ following a standard procedure [40]. The subsequent 


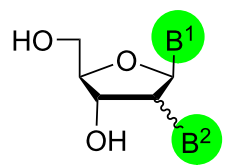

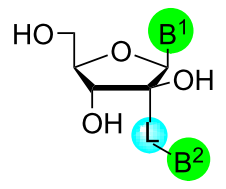

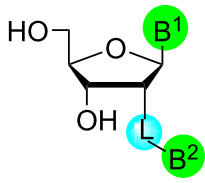<smiles>[B][C@H]1C[C@H](Br)[C@H](CO)C1</smiles><smiles>OC[C@@H]1O[C@@H]([18OH])[C@@H](O)[C@@H]1Br</smiles>

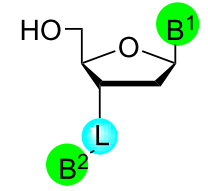

\section{1,4-DHN}

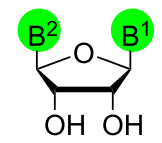<smiles>OCC(O)C1CC(Br)C1Br</smiles><smiles>OC1CC(Br)C(Br)C1O</smiles>

$1,5-\mathrm{DHN}$<smiles></smiles><smiles>OC1CC(Br)CC1[Hg]Br</smiles>

bicyclic double-headed nuleosides

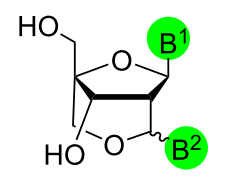<smiles>[B]C1C2OCC(CO)(CN1[Ga]Br)O2</smiles><smiles></smiles>

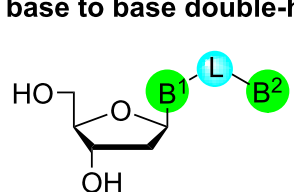

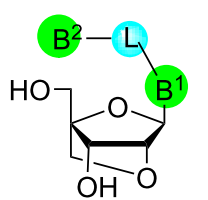

pyranosyl double-headed nucleosides<smiles>CC(=O)OC1O[C@@H]2C[C@H]1O[C@H]2C(C)=O</smiles>

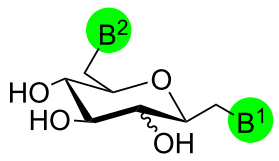<smiles>OC1CC(O)C(O)C(CBr)C(O)C1O</smiles>

acyclic double-headed nuleosides

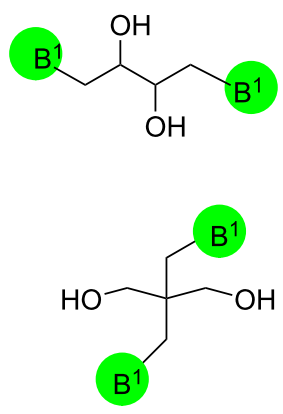<smiles>OC(O)C(O)C(O)([18OH])[18OH]</smiles>

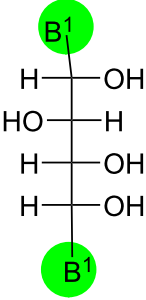

Figure 1: Double-headed nucleosides. $B^{1}$ and $B^{2}=$ nucleobases or heterocyclic/carbocyclic moieties; $L=$ linker.

Corey-Chaykovsky epoxidation [41] of 2'-ketonucloside 1 with trimethylsulfoxonium iodide in DMSO afforded the spironucleoside 2, which in turn was converted to the TIPDS-protected 2'-(pyrimidin-1-yl)methyl-/2'-(purin-9-yl)methylarabinofuranosyluracil derivatives 3a-f by nucleophilic epoxide ring opening with thymine, $\mathrm{N}$-benzoyladenine, 6-O-allyl- $\mathrm{N}$-isobutyrylguanine, $\mathrm{N}$-benzoylcytosine, 6- $\mathrm{O}$-allylhypoxanthine or $\mathrm{N}, \mathrm{N}$-dibenzoyldiaminopurine in 53 to $83 \%$ yield. The desilylation of the nucleosides 3a-f with tetrabutylammonium fluoride in tetrahydrofuran (THF) led to the formation of six different double-headed nucleosides $\mathbf{4 a - f}$ (Scheme 1) [38,39].
The synthesized double-headed nucleosides $4 \mathbf{4 a}, \mathbf{b}$ were dimethoxytritylated (DMTr), phosphitylated, and incorporated into DNA oligonucleotides using the standard automated phosphoramidite method. The UV-based melting temperature $\left(T_{\mathrm{m}}\right)$ of hybrids of the modified oligonucleotides with complementary DNA strands were studied. The analysis of the melting temperature of the duplex and extensive molecular dynamics studies revealed that the synthesized double-headed nucleotides behave as functional dinucleotide mimics and hybridize with complementary targets neatly with their Watson-Crick faces compatible with natural DNA [39]. 


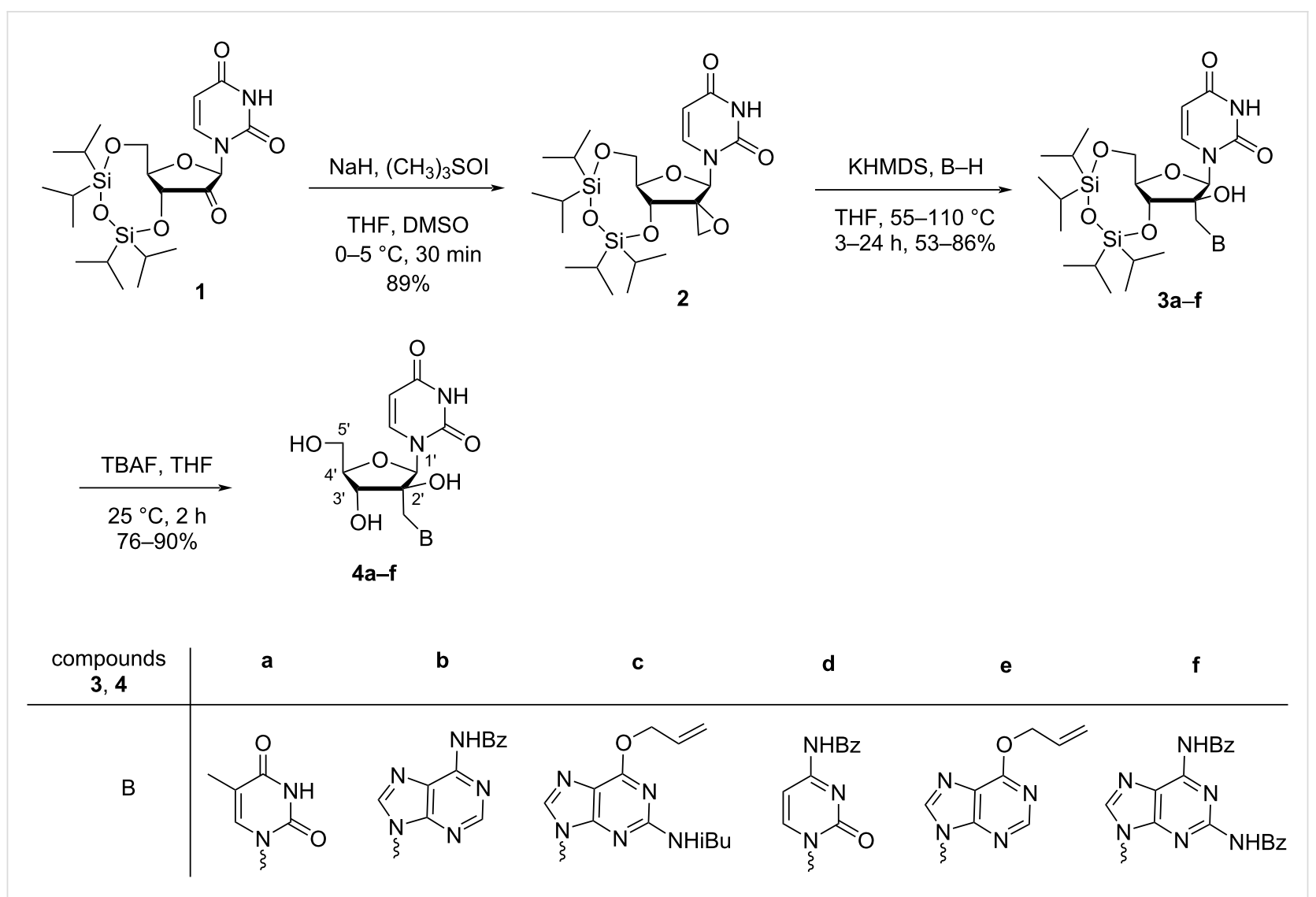

Scheme 1: Synthesis of $2^{\prime}$-(pyrimidin-1-yl)methyl- or 2'-(purin-9-yl)methyl-substituted double-headed nucleosides $4 a-f$ of arabinofuranosyluracil.

Nielsen and co-workers [42] additionally synthesized $2 '-(N-$ benzoylcytosin-1-yl)methylarabinofuranosyl- $N$-benzoylcytosine (7) from uridine using a similar methodology. Thus, the nucleophilic epoxide ring opening in spironucleoside 2 with uracil in DMF in a $N^{1}$-regioselective manner afforded the TIPDS-protected double-headed nucleoside 5 having two uracil bases (the additional uracil being attached through a methylene linker to the 2'-position of arabinouracil). Subsequently, the two uracil bases of the TIPDS-protected double-headed nucleoside 5 were converted to $\mathrm{N}$-benzoylated cytosines in a three-step onepot procedure in $55 \%$ yield. For this conversion, the carbonyl group at the 4-position of uracil was first activated by tosylation, which was followed by conversion to the amine upon reaction with ammonia and protection of the newly introduced amino group with benzoyl chloride to afford the double-headed nucleoside 6. The removal of the silyl protecting group with $\mathrm{NEt}_{3} \cdot 3 \mathrm{HF}$ in THF yielded 2 - $(N$-benzoylcytosin-1-yl)methylarabinofuranosyl- $N$-benzoylcytosine (7, Scheme 2) [42].

The double-headed nucleoside 7 was dimethoxytritylated and phosphitylated following the standard procedure and incorporated into oligonucleotides to study its effects on duplex stability. The single incorporation in oligonucleotides and study of the melting temperature $\left(T_{\mathrm{m}}\right)$ of its duplex hybridized with a complementary DNA strand revealed an increase in $T_{\mathrm{m}}$ by $4{ }^{\circ} \mathrm{C}$ with respect to the normal duplex. This indicated the participation of both nucleobases of the double-headed nucleotides in Watson-Crick base pairing. The same group also showed that a multiple incorporation of the double-headed nucleotide is also tolerated, but the double-headed nucleotides with the present design were not suitable as triplex-forming oligonucleotides [42].

Pedersen and Nielsen [35] synthesized a double-headed nucleoside with two different nucleobases, i.e., 2'-deoxy-2'-(thymine1-yl)ethyluridine (11) (Scheme 3). The oxidative cleavage of the allyl group in TIPDS-protected 2-allyl-2-deoxyuridine $\mathbf{8}$ gave the TIPDS-protected hydroxynucleoside $\mathbf{9}$ as key intermediate. The treatment of $\mathbf{9}$ with benzoyl chloride under suitable conditions to selectively protect the $3-\mathrm{NH}$ group of the uracil moiety afforded $N^{3}$-benzoyluridine (10). The reaction of TIPDS-protected hydroxynucleoside 9 with $N^{3}$-benzoylthymine under Mitsunobu reaction conditions, followed by deprotection with TBAF and aqueous methanolic ammonia resulted in the formation of $2^{\prime}$-deoxy-2'-(thymine-1-yl)ethyluridine (11) in $37 \%$ yield. When the same procedure was repeated with 

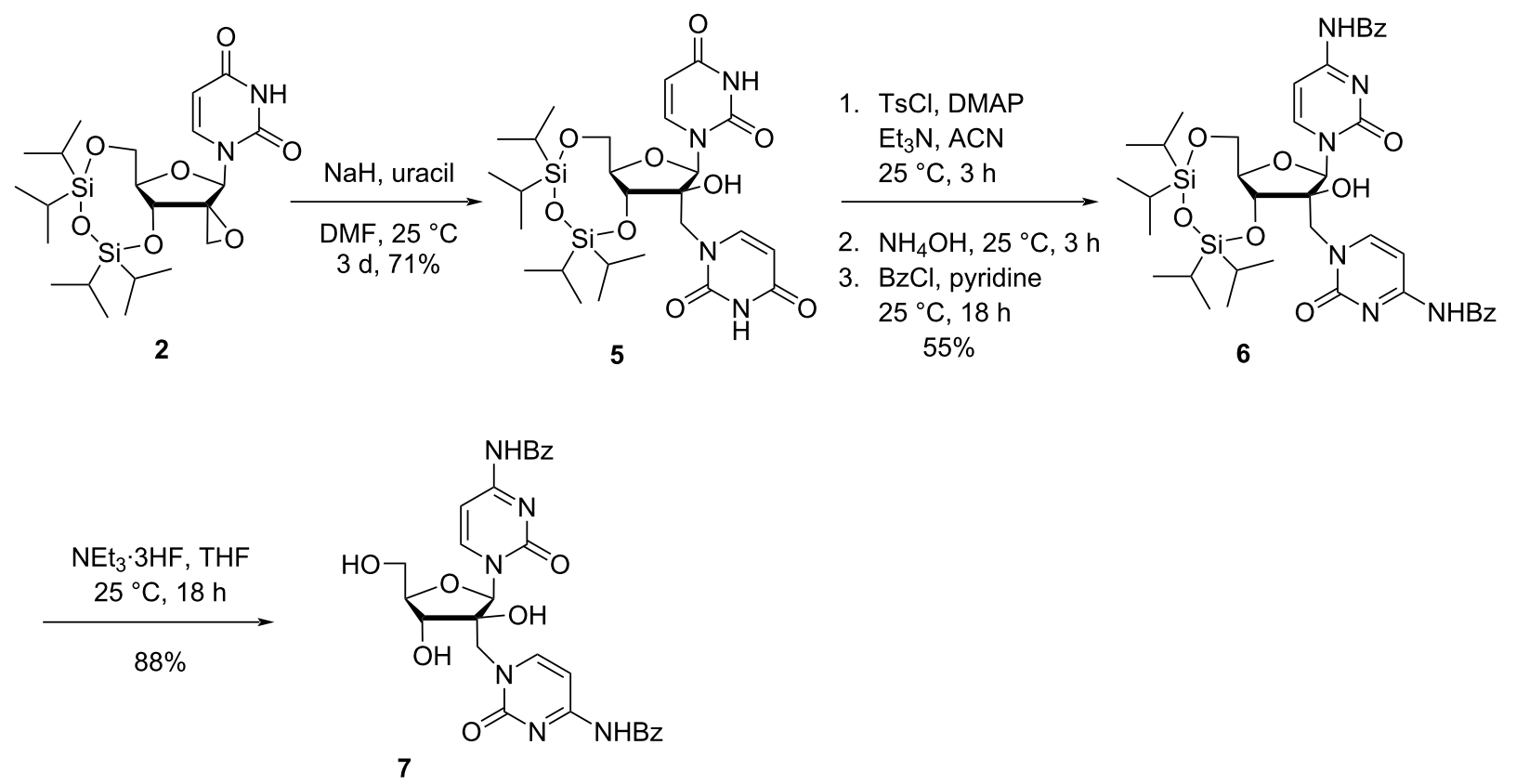

Scheme 2: Synthesis of double-headed nucleoside 7 having two cytosine moieties.

$N^{3}$-benzoyluridine (10) the double-headed nucleoside $\mathbf{1 1}$ was obtained in 67\% yield (Scheme 3) [35].

The double-headed nucleoside $\mathbf{1 1}$ was dimethoxytritylated and phosphitylated following the standard procedures and incorporated once into a 13-mer oligodeoxynucleotide and an LNAmodified oligodeoxynucleotide sequence, and four-times in the middle of a 12-mer oligodeoxynucleotide sequence in order to study the effect of the additional nucleobase in duplexes, bulged duplexes, and in three way junctions [35]. The designed doubleheaded nucleoside was found to be reasonably well tolerated in duplexes and stabilized three-way junctions. Significant conformational changes in these secondary structures have also been induced [35].

Nielsen and co-workers [43] synthesized 2'-(4-(thymin-1ylmethyl)-1,2,3-triazole-1-yl)- and 2'-(4-( $N^{6}$-benzoyladenine-9ylmethyl)-1,2,3-triazole-1-yl)-substituted double-headed nucleosides of 2'-deoxy-5'-O-(4,4'-dimethoxytrityl)uridine (14 and $\mathbf{1 5}$ ) from the nucleoside azide $\mathbf{1 2}$ which in turn was obtained by the nucleophilic opening of $O-2,2^{\prime}$-anhydrouridine [44]. The azido nucleoside 12 was reacted with $N^{6}$-benzoyl- $N^{9}$ propargyladenine (13a) and $N^{1}$-propargylthymine (13b) via a CuAAC reaction where the triazole-containing linker connected the additional thymine or adenine to the $2^{\prime}$-position of $2^{\prime}$-deoxyuridine forming the double-headed nucleosides 14 and $\mathbf{1 5}$, respectively (Scheme 4) [43].
Both double-headed nucleosides 14 and $\mathbf{1 5}$, when incorporated into oligonucleotides were found to stabilize three-way junction in both DNA-DNA and DNA-RNA duplexes and when introduced into a (+1)-zipper motif, cross strand interactions were observed in a DNA-DNA duplex [43].

TIPDS protection of uridine (16), followed by the treatment of the product with acetic anhydride/acetic acid in DMSO produced the protected nucleoside 17 [45,46] (Scheme 5). Next, the fully protected nucleoside $\mathbf{1 7}$ was subjected to chlorination using thionyl chloride in dichloromethane, followed by the treatment of the product with $N^{3}$-benzoylthymine under basic conditions $\left(\mathrm{K}_{2} \mathrm{CO}_{3}\right.$ in DMF) to produce the nucleoside 18. The removal of the tert-butyldimethylsilyl group from nucleoside 18, followed by dimethoxytritylation at the primary hydroxy and phosphitylation at the secondary hydroxy group afforded the double-headed nucleoside monomer 19 (Scheme 5) [45].

The synthesized double-headed nucleoside $\mathbf{1 9}$ was introduced in oligonucleotides and its impact on the secondary nucleic acid structure was studied. It was revealed that the double-headed nucleoside 19 was well accommodated in a hybrid DNA:RNA duplex and stabilized bulged duplex and three way junctions [45]. The potential of the double-headed nucleoside 19 in secondary nucleic acid structures was compared with the earlier reported monomer $\mathbf{1 1}$ and found to be inferior to double-headed nucleoside $\mathbf{1 1}$ due to the $3^{\prime}$-endo conformation which placed the 
<smiles>C=CCC1OCC2(CO[Si](O[Si](C(C)C)(C(C)C)C(C)C)(C(C)C)C(C)C)OC1OC2n1ccc(=O)[nH]c1=O</smiles>

8

1. $\mathrm{OsO}_{4}, \mathrm{NMO}$, aq $t-\mathrm{BuOH}, 25^{\circ} \mathrm{C}, 1.5 \mathrm{~h}$

2. $\mathrm{NalO}_{4}$, aq dioxane, $25^{\circ} \mathrm{C}, 40 \mathrm{~min}$

3. $\mathrm{NaBH}_{4}, \mathrm{MeOH}, 0^{\circ} \mathrm{C}, 40$ min $64 \%$ (overall yield)

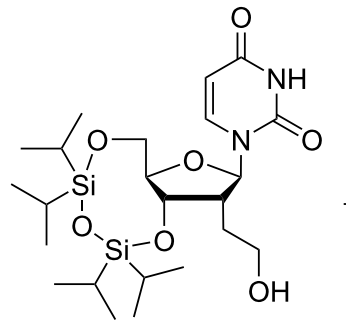

9

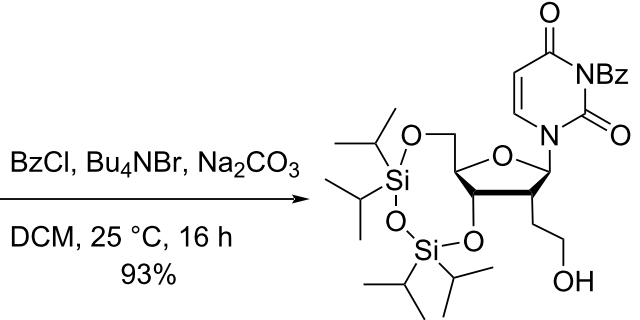

10
1. $N^{3}$-benzoylthymine $\mathrm{PPh}_{3}, \mathrm{DEAD}, \mathrm{THF}$ $0-25^{\circ} \mathrm{C}, 18 \mathrm{~h}$

2. TBAF, THF $25^{\circ} \mathrm{C}, 40 \mathrm{~min}$ 3. $\mathrm{NH}_{3}, \mathrm{CH}_{3} \mathrm{OH}, 2 \mathrm{~h}$ $67 \%$ (overall yield)<smiles>Cc1cn(CCC2C3OC(CO)(OC3O)C2n2ccc(=O)[nH]c2=O)c(=O)[nH]c1=O</smiles>

1. $N^{3}$-benzoylthymine, $\mathrm{PPh}_{3}, \mathrm{DEAD}$

THF, $0-25^{\circ} \mathrm{C}, 18 \mathrm{~h}$

2. TBAF, THF, $25^{\circ} \mathrm{C}, 40 \mathrm{~min}$

3. $\mathrm{NH}_{3}, \mathrm{CH}_{3} \mathrm{OH}, 2 \mathrm{~h}$,

$37 \%$ (overall yield)

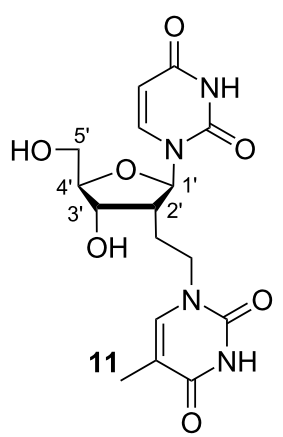

Scheme 3: Synthesis of double-headed nucleoside $2^{\prime}$-deoxy-2'-C-(2-(thymine-1-yl)ethyl)-uridine (11).

2 '-substituent towards the minor groove rather than to the duplex core [35].

Vilarrasa and co-workers [47] synthesized 2'-uracil-1-yl and 2 '-thymin-1-yl derivatives of 2'-deoxythymidine starting from uridine (16). The synthesis started with the TIPDS protection of 16 followed by introduction of an azide group in the C-2' position of the molecule to afford nucleoside 22. The treatment of azide $\mathbf{2 2}$ with pyrrolidine in acetonitrile followed by hydrogenation afforded aminonucleoside $\mathbf{2 3}$, which was used as a key intermediate for the synthesis of the double-headed nucleosides 24 and 25 (Scheme 6) [47].

The same group [47] also synthesized the C-2' isomeric nucleosides 28 and 29, i.e., with inverted configuration at C-2' as compared to nucleosides 24 and 25 (Scheme 7). The synthesis of these two nucleosides was carried out through the formation of the anhydro nucleoside $\mathbf{2 6}$ and its transformation into the aminonucleoside 27 . The key intermediate nucleoside 27 was then treated with 3-ethoxypropenoyl isocyanate or 3-methoxy- 
<smiles>COCC1OC(O)C(n2ccc(=O)[nH]c2=O)C1N</smiles>

12

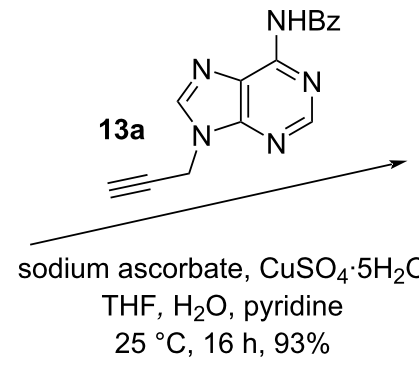

sodium ascorbate, $\mathrm{CuSO}_{4} \cdot 5 \mathrm{H}_{2} \mathrm{O}$

$t$ - $\mathrm{BuOH}, \mathrm{H}_{2} \mathrm{O}$, pyridine

$25^{\circ} \mathrm{C}, 19 \mathrm{~h}, 72 \%$<smiles>C#CCn1cc(C)c(=O)[nH]c1=O</smiles><smiles>COCCOC(C(O)COC)n1ccc(=O)[nH]c1=O</smiles>

14<smiles>Cc1cn(Cc2cn(C[C@@H](OC(C)(C)O[Na])n3ccc(=O)[nH]c3=O)nn2)c(=O)[nH]c1=O</smiles>

15

Scheme 4: Double-headed nucleosides 14 and 15 obtained by click reaction.

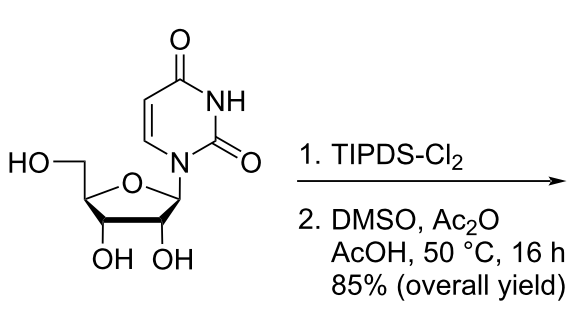

16

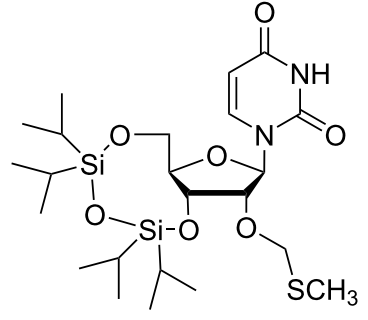

17
1. $\mathrm{SO}_{2} \mathrm{Cl}_{2}$

$25^{\circ} \mathrm{C}, 2 \mathrm{~h}$

2. $N^{3}$-benzoylthymine $\mathrm{K}_{2} \mathrm{CO}_{3}$, DMF $25^{\circ} \mathrm{C}, 16 \mathrm{~h}$

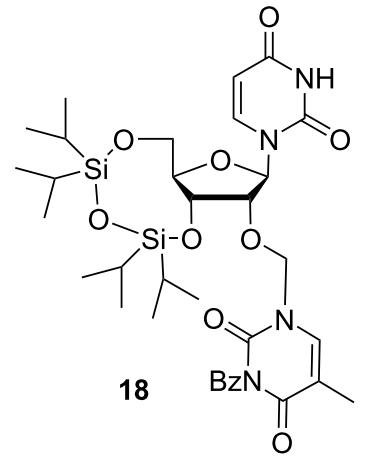

1. TBAF, THF $25^{\circ} \mathrm{C}, 2 \mathrm{~h}$

2. DMTr-Cl, Pyr $25^{\circ} \mathrm{C}, 14 \mathrm{~h}, 70 \%$

3. $\mathrm{P}(\mathrm{OCE}) \mathrm{N}(\mathrm{iPr})_{2} \mathrm{Cl}$ $25^{\circ} \mathrm{C}, 15 \mathrm{~h}$

$70 \%$ (overall yield)

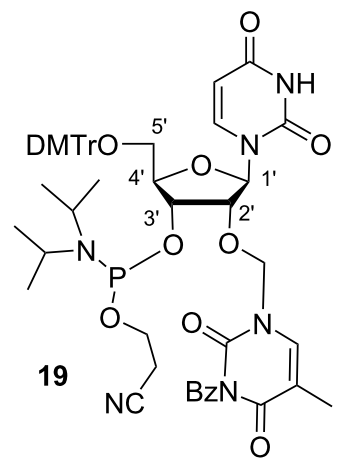

Scheme 5: Synthesis of the double-headed nucleoside 19.

2-methylpropenoyl isocyanate in a mixture of benzene and DMF, followed by acidification with sulfuric acid affording the nucleosides $\mathbf{2 8}$ and $\mathbf{2 9}$, respectively in high yields (Scheme 7) [47].
Nielsen and co-workers [33] synthesized the double-headed nucleoside $2^{\prime}$ - $C$-(thymine-1-yl)methyl-2'-deoxyuridine (33) starting from the ribose derivative 3,5-bis- $O$-( $p$-chlorobenzyl)2-deoxy-2-hydroxymethyl- $\alpha$-D-ribofuranose (30) which in turn 


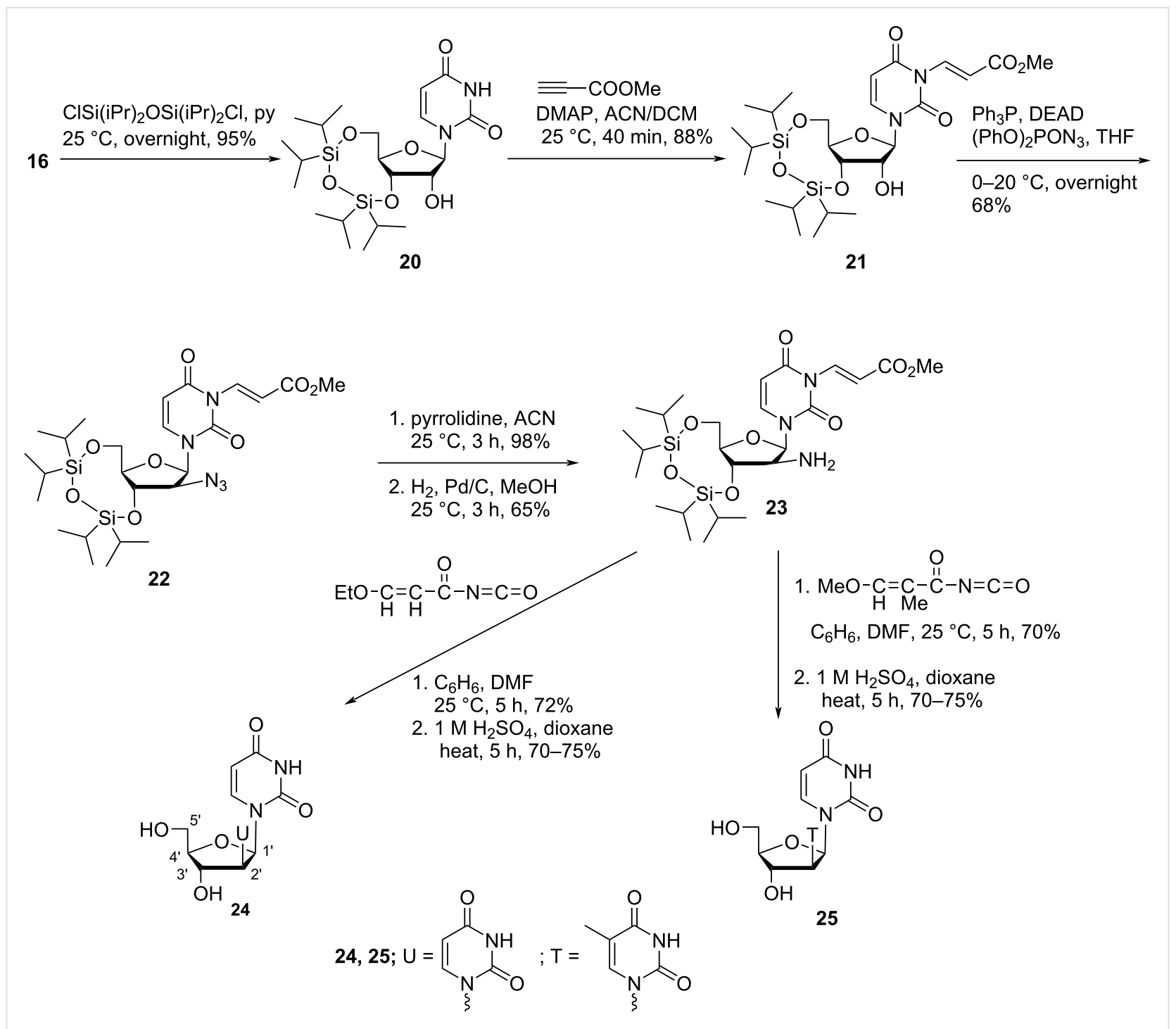

Scheme 6: Synthesis of the double-headed nucleosides 24 and 25.

was synthesized from D-ribose in six steps following a procedure reported in the literature [48]. The Mitsunobu reaction of ribose derivative $\mathbf{3 0}$ and $N^{3}$-(benzyloxymethyl)thymine afforded nucleoside $\mathbf{3 1}$ which was subjected to Vorbrüggen coupling with silylated uracil to give the protected doubleheaded nucleoside 32. Global deprotection of $\mathbf{3 2}$ using palladium-catalyzed hydrogenation conditions resulted in the formation of the targeted double-headed nucleoside $\mathbf{3 3}$ (Scheme 8) [33].

The double-headed nucleoside $\mathbf{3 3}$ was dimethoxytritylated, phosphitylated, and incorporated into duplex and its ability to recognize complementary base pairs was monitored by UV melting curve analysis [33]. Hybridization data revealed that the synthesized double-headed nucleotide recognized itself either through formation of Watson-Crick base pairs with two com- plementary adenosines or through the formation of $\mathrm{T}: \mathrm{T}$ (thymine:thymine) base pairs that resulted in the formation of two novel nucleic acid motifs. The novel nucleic acid motifs could be incorporated either single or multiple times in dsDNA duplexes without altering its stability. It was revealed by molecular dynamics (MD) simulations that the DNA sugar-phosphate backbone accommodated modified nucleotide by stretching or curling up as required and all the four base pairs based upon the structure of the synthesized double-headed nucleotide could be accommodated in the similar way as the T:A (thymine:adenine) base pair in the motif. The nucleic acid motifs may also be used in designing nanoscale DNA structures where a specific duplex twist is required [33].

Nielsen and co-workers [34] also synthesized the doubleheaded nucleoside $2^{\prime}-C$-( $N^{6}$-benzoyladenine-9-yl)methyl-2'- 


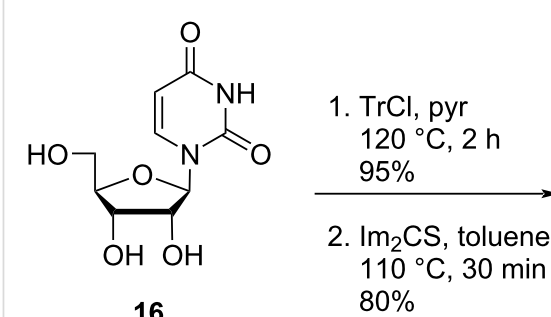

16<smiles></smiles>

26
1. $\mathrm{Me}_{3} \mathrm{SiN}_{3}$, LiF, DMF TMEDA, $110^{\circ} \mathrm{C}, 48 \mathrm{~h}$ $60 \%$

2. $\mathrm{SnCl}_{2}, \mathrm{PhSH}, \mathrm{Et}_{3} \mathrm{~N}$ $\mathrm{CH}_{3} \mathrm{CN}, 25^{\circ} \mathrm{C}, 30 \mathrm{~min}$ 95\%<smiles></smiles>

27

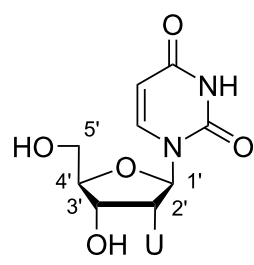

28

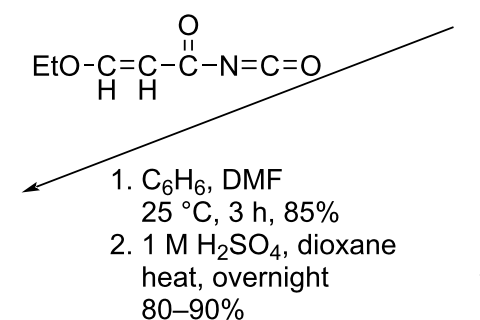

$\mathrm{MeO}-\underset{\mathrm{H}}{\mathrm{C}}=\stackrel{\mathrm{O}}{\mathrm{M}}-\stackrel{-}{\mathrm{C}}-\mathrm{N}=\mathrm{C}=\mathrm{O}$

1. $\mathrm{C}_{6} \mathrm{H}_{6}, \mathrm{DMF}$

$25^{\circ} \mathrm{C}, 3 \mathrm{~h}, 85 \%$

2. $1 \mathrm{M} \mathrm{H}_{2} \mathrm{SO}_{4}$, dioxane heat, overnight 80-90\%

28, 29; $U=$<smiles>Cc1cn(C)c(=O)[nH]c1=O</smiles>

Scheme 7: Synthesis of double-headed nucleosides 28 and 29.
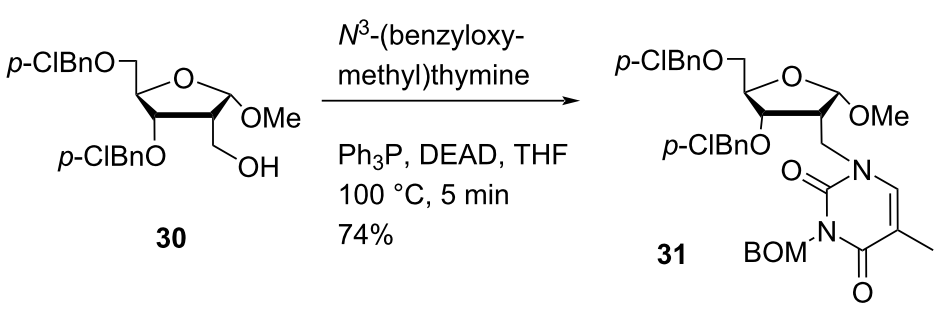

uracil, BSA, TMS-OTf

$\mathrm{CH}_{3} \mathrm{CN}, 25^{\circ} \mathrm{C}, 20 \mathrm{~h}$ $64 \%$

29 
chloride via Vorbrüggen coupling afforded the protected double-headed nucleoside $\mathbf{3 6}$. The nucleoside $\mathbf{3 6}$ was finally deprotected in the presence of $\mathrm{Pd}(\mathrm{OH})_{2} / \mathrm{C}$ under hydrogen atmosphere to generate the double-headed nucleoside $\mathbf{3 7}$ (Scheme 9) [34].

The double-headed nucleoside $\mathbf{3 7}$ was dimethoxytritylated, phosphitylated, and incorporated into 11- to 13-mer oligonucleotides using the standard automated phosphoramidite method. The UV-based melting temperature $\left(T_{\mathrm{m}}\right)$ of hybrids of the modified oligonucleotides with complementary DNA strands were studied. The analysis of the melting temperature of the resulting duplex revealed that the synthesized doubleheaded nucleotide behaved as a compressed dinucleotide and combination of all natural nucleobases on compressed scaffold can form Watson-Crick base pairs with complementary bases [34].

Nielsen and co-workers [23] synthesized the double-headed nucleoside 1-(5'-O-(4,4'-dimethoxytrityl)-2'-C-((4-(pyren-1-yl)1,2,3-triazole-1-yl)methyl)arabinofuranosyl)uracil (41) starting from spironucleoside $\mathbf{2}$ which in turn was synthesized from uridine following a procedure reported in the literature $[30,32,49]$. The spironucleoside 2 was then reacted with sodium azide to afford the arabino-uridine $\mathbf{3 8}$ with an azidomethyl group in the $\mathrm{C}-2^{\prime}$ position. The arabino-uridine $\mathbf{3 8}$ was reacted with TBAF and 4,4'-dimethoxytrityl chloride to afford nucleoside 39 which was reacted with 1-ethynylpyrene (40) under copper-catalyzed alkyne-azide cycloaddition (CuAAC) reaction conditions to yield the double-headed nucleoside $\mathbf{4 1}$ (Scheme 10) [23].

The double-headed nucleoside $\mathbf{4 1}$ was phosphitylated and then incorporated into oligonucleotides and was found to form highly stable DNA duplexes and three way junctions. There was a four-fold increase in the intensity of the pyrene excimer signal observed when an oligonucleotide containing two incorporations of the double-headed nucleoside $\mathbf{4 1}$ hybridized with an RNA target whereas the pyrene-pyrene excimer band almost vanished when the oligonucleotide was hybridized with a DNA target. The double-headed nucleoside $\mathbf{4 1}$ has potential in DNA invader probes as well as in RNA targeting and detection [23].

\section{1,3-Furanosyl double-headed nucleosides}

In this section, all double-headed nucleosides with furanosyl ring structures are collected. The first nucleobase is attached at the anomeric position of the furanosyl ring structure and the second nucleobase is connected to the C-3' position with or without a linker (Figure 1).

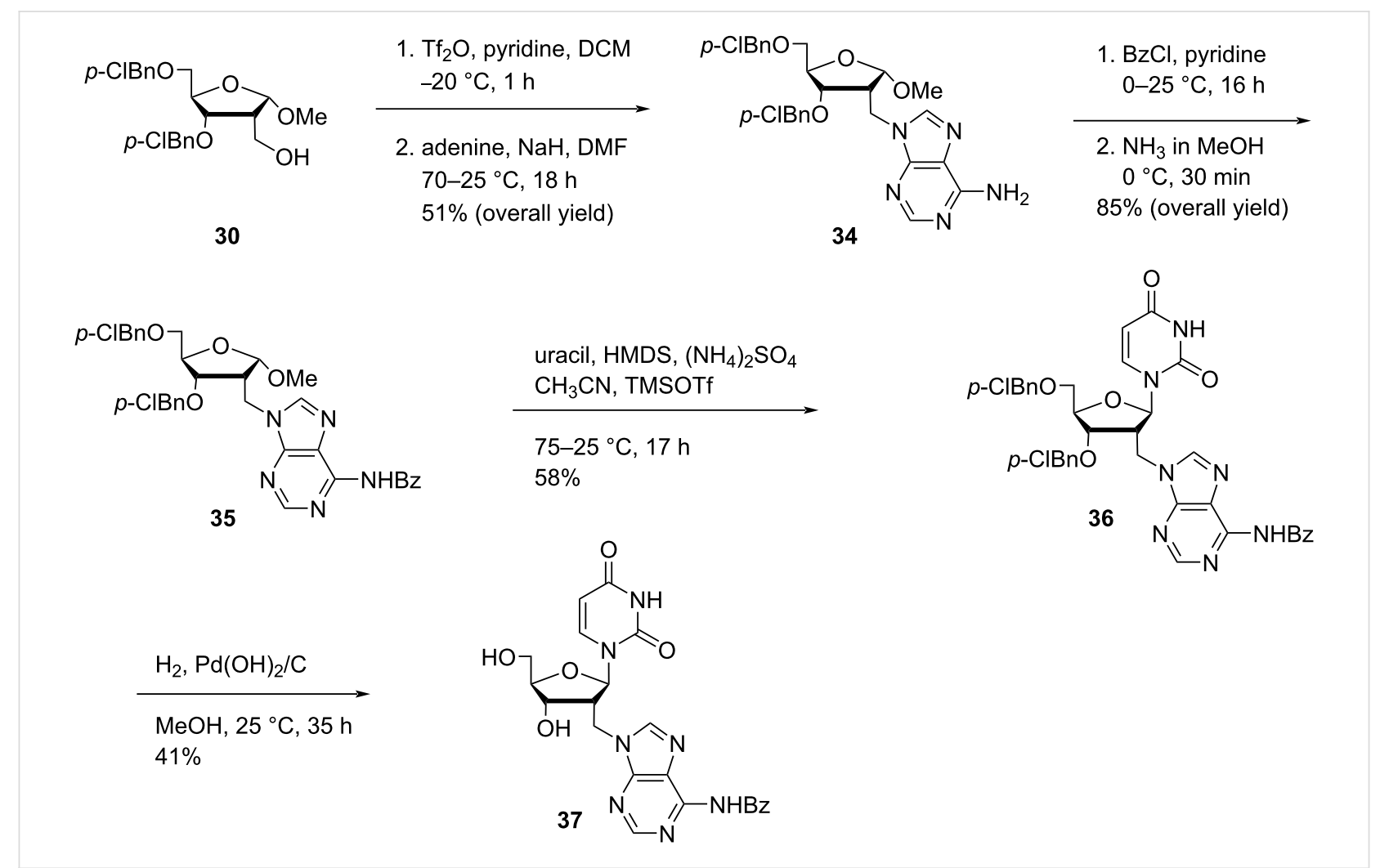

Scheme 9: Synthesis of double-headed nucleoside 37 

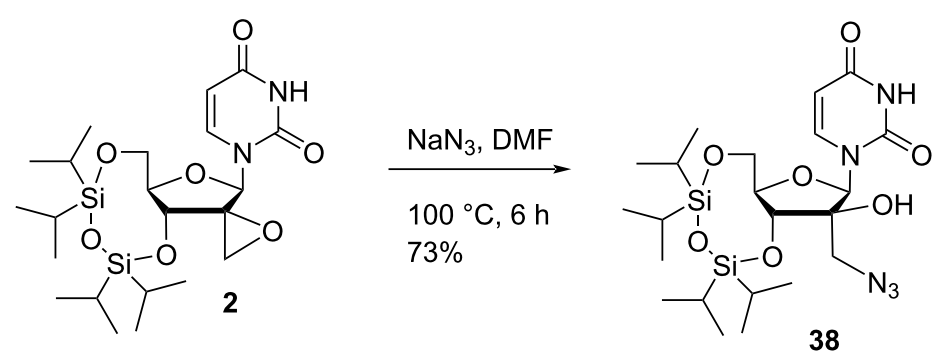
1. TBAF, THF $25^{\circ} \mathrm{C}, 2 \mathrm{~h}$ $80 \%$
2. DMTrCl, pyridine $25{ }^{\circ} \mathrm{C}, 16 \mathrm{~h}$ $83 \%$<smiles>COCC1(O)OCCOCC(O)(CN)C1O</smiles>

39

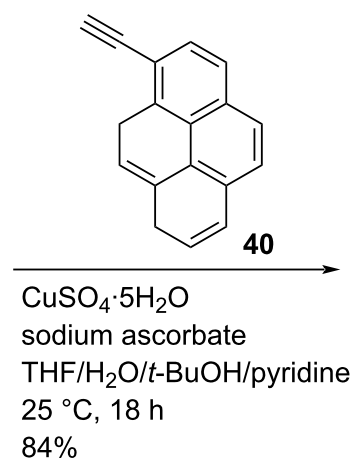<smiles>COOCC1(O)OC2(O)Cn3cc(nn3)-c3ccc(c4c3CC=C3C=CC=C3C=C4)C1C2(O)n1ccc(=O)[nH]c1=O</smiles>

Scheme 10: Synthesis of the double-headed nucleoside 1-(5'-O-(4,4'-dimethoxytrityl)-2'-C-((4-(pyren-1-yl)-1,2,3-triazole-1-yl)methyl)arabinofuranosyl)uracil (41).

Leonaidas and co-workers [36] have synthesized 3'-(4((adenine-9-yl)methyl)-1,2,3-triazol-1-yl)-substituted doubleheaded nucleosides of 1-( $\beta$-D-ribofuranosyl)uracil/thymine/5fluorouracil 46a-c and 3'-(4-((pyrimidin-1-yl)methyl)-1,2,3triazol-1-yl)-substituted double-headed nucleosides of 9-( $\beta$-Dribofuranosyl)adenine/ $N^{6}$-benzoyladenine 50a-e. The synthesis started from C-3-azidoribofuranose $\mathbf{4 2}$ which in turn was obtained from 1,2:5,6-di- $O$-isopropylidene-D-glucose [50]. Furanoside 42 was reacted with the silyl-protected nucleobases 43a-c and 47a,b in the presence of trimethylsilyl trifluoromethanesulfonate in acetonitrile to give the $3^{\prime}$-azido- $3^{\prime}$-deoxy- $\beta$ D-ribonucleosides 44a-c and 48a,b via Vorbrüggen coupling reaction. The nucleosides were further reacted with propargylated nucleobases through a copper-catalyzed azide-alkyne cycloaddition ( $\mathrm{CuAAC}$ ) reaction followed by treatment with methanolic ammonia to give the C-3'-substituted double-headed ribofuranonucleosides 46a-c and 50a-e (Scheme 11) [36].

The double-headed nucleosides 46a-c and 50a-e were evaluated for their inhibitory potency towards RNase A and eosinophil-derived neurotoxin (EDN). Among all the nucleosides, the double-headed nucleoside 50c showed a stronger preference for EDN than for ribonuclease A whereas all other derivatives were found to be more specific for ribonuclease $\mathrm{A}$ [36].
Lazrek et al. [51] synthesized C-3'-modified double-headed nucleosides 54a-g where a 1,2,3-triazol ring acts as linker of the nucleobase and the sugar moiety. First, seven $N^{9} / N^{1}$-propargylpurine/pyrimidine nucleobases $\mathbf{1 3 b}, \mathbf{4 5}$, and 53a-g were synthesized by treating the nucleobases with propargyl bromide in the presence of $\mathrm{K}_{2} \mathrm{CO}_{3}$. The synthesis of compounds $\mathbf{5 4 a}-\mathbf{g}$ started with $\beta$-D-lyxofuranosylthymine (51), which was first methoxytritylated at the $\mathrm{C}-5^{\prime}$ primary hydroxy position followed by mesylation of the C-3' secondary hydroxy position. The subsequent treatment with sodium azide in DMF afforded the corresponding nucleoside $\mathbf{5 2}$ [52]. Triazolylation of compound 52 with the nucleobases $13 \mathrm{~b}, \mathbf{4 5}$, and $\mathbf{5 3 a - g}$ by refluxing the substrates in toluene afforded the targeted 5'-Omonomethoxytritylated nucleosides 54a-g (Scheme 12) [51].

Vilarrasa and co-workers [47] synthesized 3'-uracil-1-yl and $3^{\prime}$-thymin-1-yl derivatives of 2 -deoxythymidine, i.e., compounds 59 and 60 starting from 5 '- $O$-tritylthymidine (55). The tritylated thymidine $\mathbf{5 5}$ first was converted to the protected azide derivative $\mathbf{5 7}$ in two steps, followed by its reduction in the presence of tin(II) chloride, thiophenol and triethylamine and treatment with pyrrolidine in acetonitrile to afford the C-3'aminonucleoside 58. The reaction of this key intermediate with 3-ethoxypropenoyl isocyanate or 3-methoxy-2-methylpropenoyl isocyanate in a solvent mixture of benzene and DMF, 


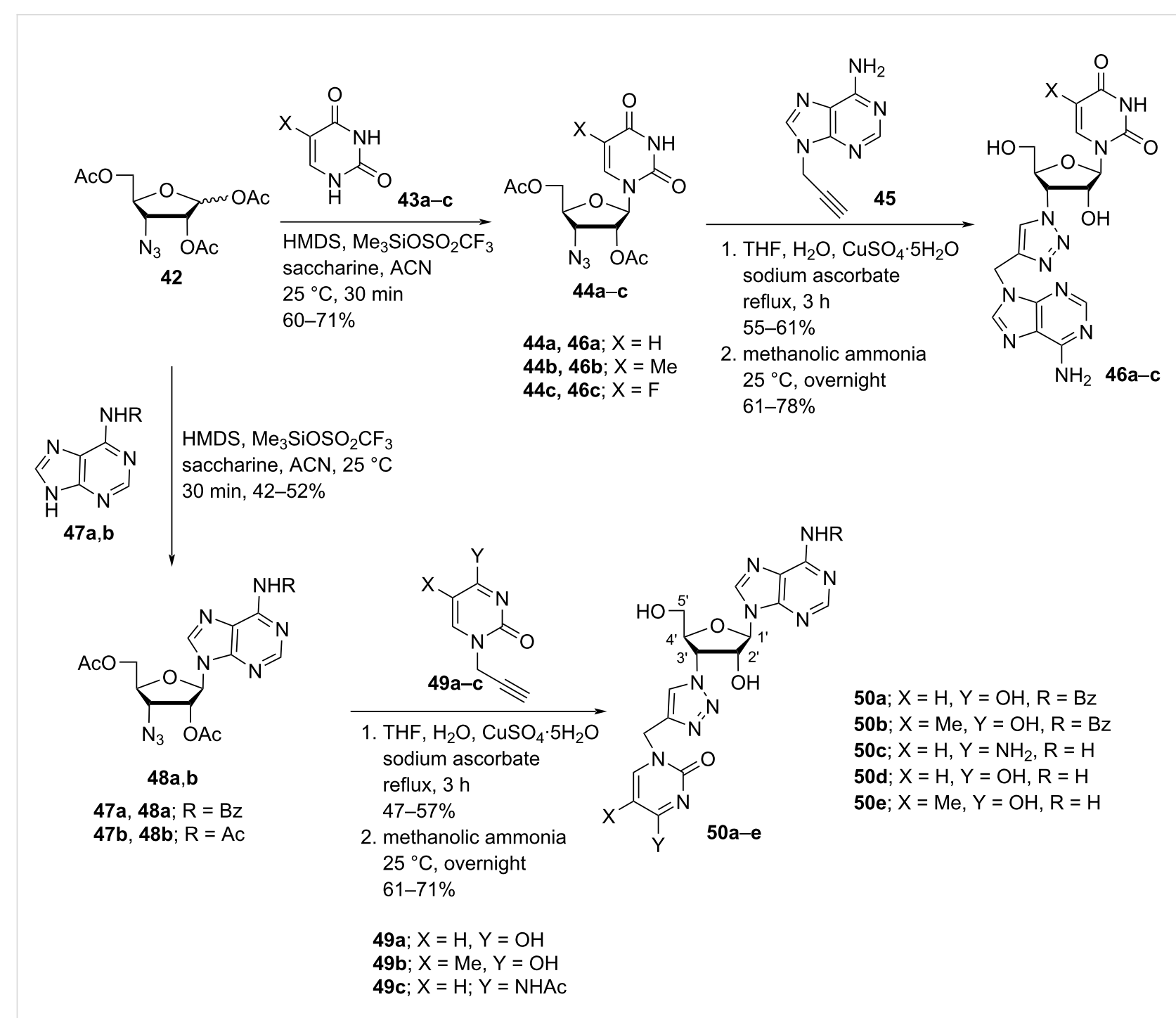

Scheme 11: Synthesis of triazole-containing double-headed ribonucleosides $46 a-c$ and $50 a-e$.



Scheme 12: Synthesis of double-headed nucleosides $54 a-g$. 
followed by acidification with sulfuric acid produced the desired nucleosides 59 and 60, respectively (Scheme 13) [47].

Vilarrasa and co-workers [47] also synthesized the doubleheaded nucleosides 63 and 64 with downwards orientation of the additional nucleosides at the $\mathrm{C}-3^{\prime}$ position. The synthesis was carried out via formation of anhydride 61. Azidation, followed by reduction of the corresponding nucleoside with tin chloride produced nucleoside $\mathbf{6 2}$ which was treated as a key intermediate for the production of the double-headed nucleosides 63 and 64. Reaction of nucleoside 62 with 3-ethoxypropenoyl isocyanate or 3-methoxy-2-methylpropenoyl isocyanate in a solution mixture of benzene and DMF, followed by acidification with sulfuric acid produced nucleosides 63 and 64, respectively (Scheme 14) [47].

\section{1,4-Furanosyl double-headed nucleosides}

A literature search revealed two different categories of 1,4-furanosyl double-headed nucleosides. In the first category, the first nucleobase was a natural (attached at C-1' position) and the second nucleobase was an aromatic moiety, which was at- tached at the C-4' position without any linker (Figure 1). Whereas the second category of nucleosides contained first natural nucleobase at the $\mathrm{C}-1^{\prime}$ position and a second natural nucleobase attached at the $\mathrm{C}-4^{\prime}$ position with a methylene linker. The nucleosides of the second type may also contain a hydroxymethyl group at the $\mathrm{C}-4^{\prime}$ position.

Torrence and co-workers [11] synthesized triazolophthalazinesubstituted double-headed nucleosides 66a-c from uridine/ adenosine-5'-carboxylic acids $\mathbf{6 5 a}-\mathbf{c}$ which in turn were prepared through the (2,2,6,6-tetramethylpiperidin-1-oxyl) (TEMPO) and 1,1-bis(acetoxy)iodobenzene (BAIB)-assisted oxidation of the 5'-hydroxymethylene group in adenosine/ uridine by following the methodology developed by Epp and Widlanski [53]. The nucleoside-5'-carboxylic acids 65a-c were reacted with 2-(1H-7-azabenzotriazol-1-yl)-1,1,3,3-tetramethyluronium hexafluorophosphate (HATU) as coupling reagent followed by reaction with phthalazin-1-ylhydrazin hydrochloride in DMF in the presence of diisopropylethylamine (DIPEA) as base to afford the double-headed nucleosides 66a-c (Scheme 15) [11].

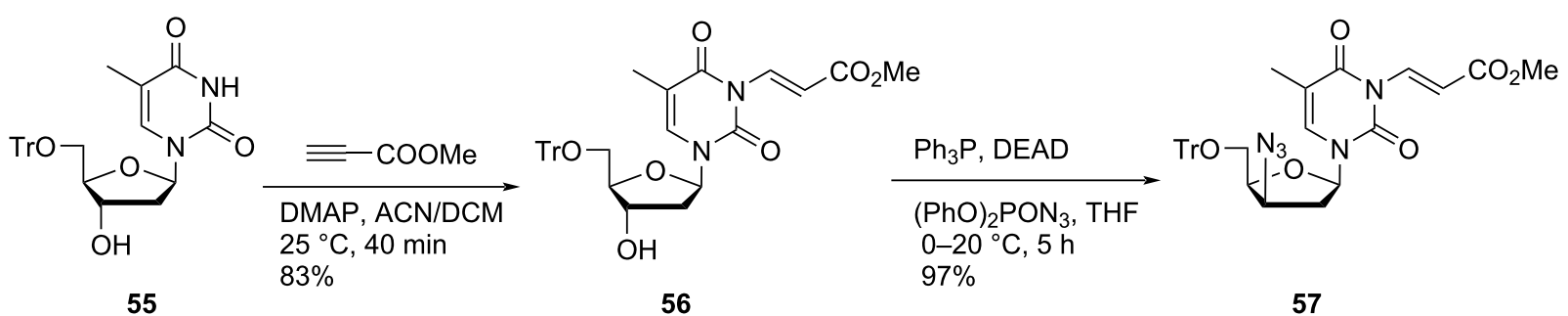

1. $\mathrm{SnCl}_{2}, \mathrm{PhSH}, \mathrm{Et}_{3} \mathrm{~N}$ $\mathrm{CH}_{3} \mathrm{CN}, 25^{\circ} \mathrm{C}, 5 \mathrm{~h}$ $75 \%$

2. pyrrolidine, $\mathrm{CH}_{3} \mathrm{CN}$ $25^{\circ} \mathrm{C}, 4 \mathrm{~h}$ $94 \%$<smiles></smiles>

58<smiles>CCOC=CC(=O)N=C=O</smiles>

1. $\mathrm{C}_{6} \mathrm{H}_{6}, \mathrm{DMF}$

$25^{\circ} \mathrm{C}, 2 \mathrm{~h}$

$90 \%$

2. $1 \mathrm{M} \mathrm{H}_{2} \mathrm{SO}_{4}$, dioxane heat, $4 \mathrm{~h}$ $80-85 \%$<smiles>CO/C=C/C(=O)N=C=O</smiles><smiles>Cc1cn(C2CC3CCC2(CO)O3)c(=O)[nH]c1=O</smiles>

59

60 


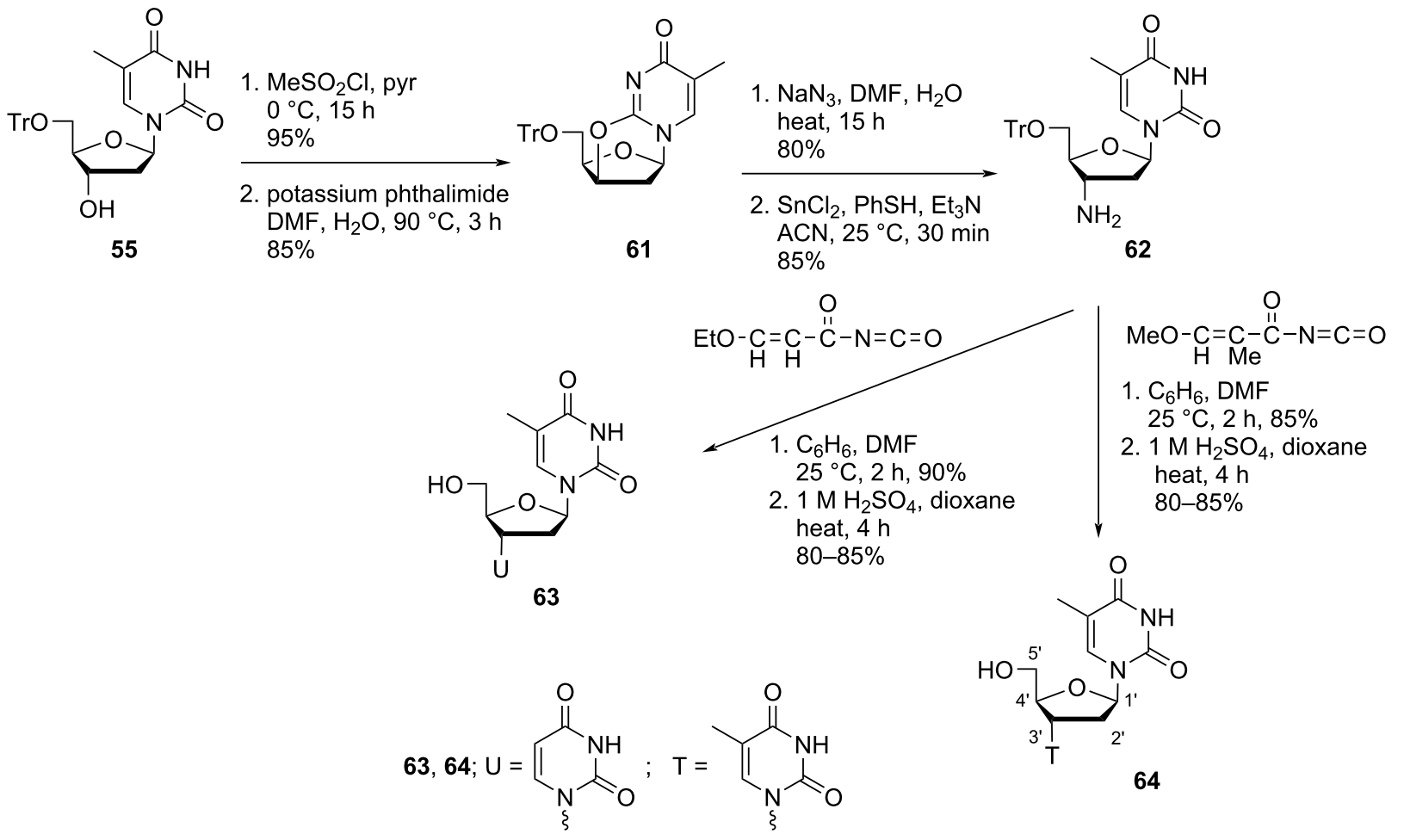

Scheme 14: Synthesis of the double-headed nucleosides 63 and 64

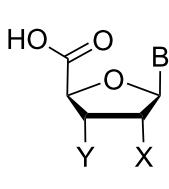

$65 a-c$
1. HATU, DMF, DIPEA $0^{\circ} \mathrm{C}, 3 \mathrm{~min}$<smiles></smiles>

$0-25^{\circ} \mathrm{C}$, overnight

3. TFA/DCM/ $/ \mathrm{H}_{2} \mathrm{O}, 25^{\circ} \mathrm{C}, 2 \mathrm{~h}$ $19-25 \%$ (overall yield)

65a, 66a; $B=$ uracil-1-yl; $X=Y=O H$

65b, 66b; $B=$ uracil-1-yl; $X=Y=H$

65c, 66c; $B=$ adenine-9-yl; $X=Y=O H$
Scheme 15: Synthesis of double-headed nucleosides $66 a-c$.

Timoshchuk and Hogrefe [12] have synthesized the doubleheaded nucleosides $(R)-N^{1}$-(4-(4,6-di-tert-butylbenzoxazol-2yl)-2',3'-O-isopropylidene- $\beta$-D-erythrofuranosyl)uracil (69) and (R)- $N^{9}$-(4-(4,6-di-tert-butylbenzoxazol-2-yl)-2'-deoxy- $\beta$-Derythrofuranosyl)adenine (71) by the reaction of 3,5-di-tertbutyl-1,2-benzoquinone with $5^{\prime}$-amino-5'-deoxy-2', $3^{\prime}-O$ isopropylideneuridine (67) and $5^{\prime}$-amino- $2^{\prime}, 5^{\prime}$-dideoxyadeno- sine (70). The unprotected double-headed nucleoside $(R)-N^{1}$-(4(4,6-di-tert-butylbenzoxazol-2-yl)- $\beta$-D-erythrofuranosyl)uracil (69) was obtained by acidic hydrolysis of the intermediate benzoxazole derivative $\mathbf{6 8}$ (Scheme 16) [12].

Herdewijn and co-workers [54] synthesized the double-headed nucleoside monomers $4^{\prime}-C-\left(\left(N^{6}\right.\right.$-benzoyladenin-9yl)methyl)thymidine (75) and $4^{\prime}-C$-((thymin-1-yl)methyl)thymidine (77) starting from 3'-O-(tert-butyldimethylsilyl)-4'(hydroxymethyl)thymidine (72) which was conveniently synthesized from thymidine in five steps as reported in the literature [54-56]. The nucleoside $\mathbf{7 2}$ was then converted into the corresponding triflate derivative which was further reacted with the nucleobases adenine or thymine to afford compounds $\mathbf{7 3}$ and 76, respectively (Scheme 17) [54].

The tert-butyldimethylsilyl-protected (TBDMS) nucleoside $\mathbf{7 6}$ was first hydrolyzed using $\mathrm{NaOH}$, which was followed by TBDMS deprotection using tetra- $n$-butylammonium fluoride (TBAF) in tetrahydrofuran (THF) to afford the double-headed nucleoside 77. The TBDMS-protected nucleoside 73 was first hydrolyzed using $\mathrm{NaOH}$ followed by the reaction with TBDMSCl and benzoyl chloride to get the $N^{6}$-benzoyl-3', $5^{\prime}-O$ diTBDMS-protected nucleoside 74. Removal of the silylprotecting groups in the double-headed nucleoside $\mathbf{7 4}$ with 


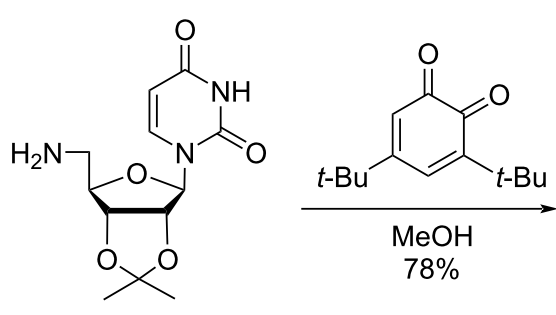

67<smiles>CC(C)(C)c1cc(C(C)(C)C)c2oc(C3OC4COC(C(C)(C)C)(O4)C3n3ccc(=O)[nH]c3=O)nc2c1</smiles>

68

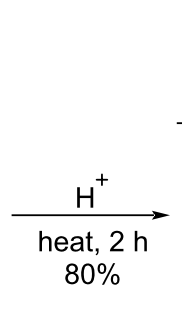<smiles>CC(C)(C)c1cc(C(C)(C)C)c2oc(C3OC4C(O)OC3C4O)nc2c1</smiles>

69<smiles>CN1OC2CC1C(O)(CN)C2</smiles>

70

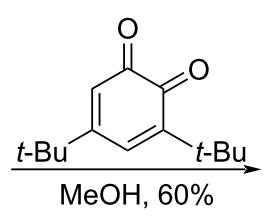

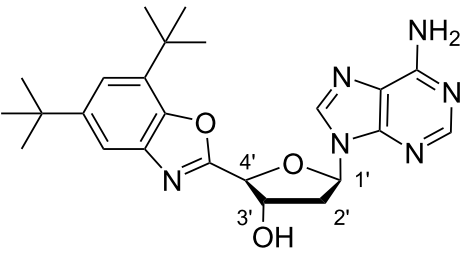

71

Scheme 16: Synthesis of benzoxazole-containing double-headed nucleosides 69 and 71 from $5^{\prime}$-amino-5'-deoxynucleoside 67.

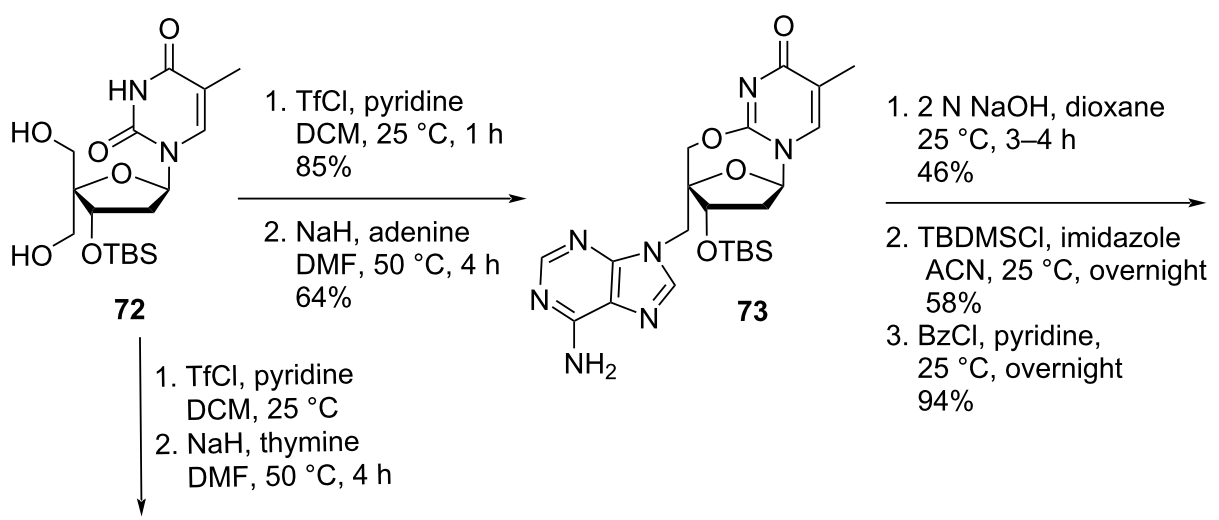<smiles>Cc1cn2c(nc1=O)OC1(Cn3cc(C)c(=O)[nH]c3=O)CC2OCC1O</smiles>

1. $2 \mathrm{~N} \mathrm{NaOH}$, dioxane $25^{\circ} \mathrm{C}, 3-4 \mathrm{~h}$

2. TBAF, THF, $25^{\circ} \mathrm{C}, 4 \mathrm{~h}$ $12 \%$ (overall yield)<smiles></smiles>

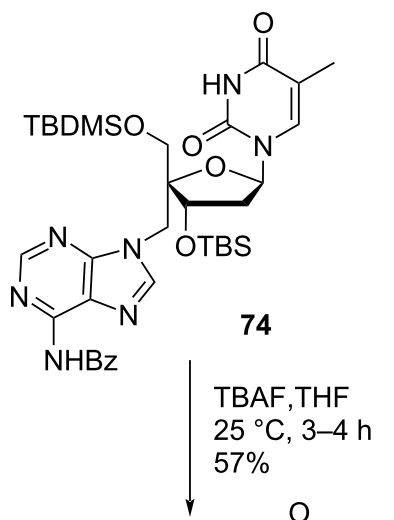<smiles></smiles>

Scheme 17: Synthesis of $4^{\prime}-C-\left(\left(N^{6}\right.\right.$-benzoyladenin-9-yl)methyl)thymidine (75) and $4^{\prime}-C-(($ thymin-1-yl)methyl)thymidine (77).

TBAF in THF resulted in the formation of the desired doubledheaded nucleoside 75 (Scheme 17) [54].

The double-headed nucleosides $\mathbf{7 5}$ and $\mathbf{7 7}$ were 4-methoxytritylated and phosphitylated following the standard procedures and incorporated into oligonucleotides. Extrahelical A-T base interactions were observed when these double-headed nucleoside monomers were placed in opposite strands of the duplex with separation of one regular base pair from each other [54].

\section{1,5-Furanosyl double-headed nucleosides}

In this category, the nucleosides contain the first natural nucleobase at the $\mathrm{C}-1^{\prime}$ position and the second natural nucleobase/aro- 
matic moiety/heterocyclic ring attached at the $\mathrm{C}-5^{\prime}$ position with or without a linker (Figure 1).

Shen and co-workers $[57,58]$ proposed the synthesis of the double-headed nucleosides 5 '-(adenine-9-yl)-5'-deoxythymidine (79) and 5'-(adenine-9-yl)-2',5'-dideoxyadenosine (81) from $2^{\prime}$-deoxy-5'-O-tosylthymidine/adenosine $\mathbf{7 8}$ and $\mathbf{8 0}$, respectively. The 2'-deoxy-5'-O-tosyl nucleosides were reacted with the sodium salt of adenine in DMF to afford the doubleheaded nucleosides $\mathbf{7 9}$ and $\mathbf{8 1}$, respectively (Scheme 18) [57,58].

Žinić and co-workers [59] synthesized 5'-(5-iodouracil-1yl)uridine (85), 5'-(5-iodouracil-1-yl)-5'-deoxyadenosine (86) and $5^{\prime}$-(uracil-1-yl)-5'-deoxyuridine (87) starting from the "reversed" 5-iodouracil-1-yl nucleoside $\mathbf{8 3}$ which in turn was synthesized by reacting the sodium salt of 5-iodouracil with isopropylidene-protected ribofuranoside 82 [55,59]. The reversed nucleoside $\mathbf{8 3}$ was next suitably protected to form nucleoside $\mathbf{8 4}$ which was then reacted with either uracil or $N^{6}$-benzoyladenine via Vorbrüggen's method of nucleobase coupling to produce the double-headed nucleosides $\mathbf{8 5}$ and $\mathbf{8 6}$. Catalytic hydrogenolysis of the iodinated double-headed nucleoside $\mathbf{8 5}$ gave the nucleoside 87 (Scheme 19) [59].

Horton and Tsai [13] synthesized double-headed nucleosides 2,6-dichloro-9-(2,3,5-tri- $O$-acetyl-5- $C$-(3-mesitylisoxazol-5-yl)$\alpha$-L-idopentofuranosyl)- $9 H$-purine (91) and 2,6-dichloro-9(2,3,5-tri- $O$-acetyl-5- $C$-(1-phenyl-1,2,3-triazol-4-yl)- $\beta$-Dglucopentofuranosyl)- $9 \mathrm{H}$-purine (92) starting from 3,5-di- $O$ acetyl-6,7-dideoxy-1,2- $O$-isopropylidene-L-ido/ $\alpha$-D-gluco-hept6-ynofuranoses 88a,b The L-ido- and D-gluco precursors 88a,b were reacted with trifluoroacetic acid followed by acetic anhydride to afford the 1,2,3,5-tetra- $O$-acetyl nucleoside analogs 89a and 89b, respectively. Montgomery and Hewson base coupling reaction [60] of 1,2,3,5-tetra- $O$-acetyl nucleoside analogues 89a and 89b with 2,6-dichloropurine under acidic conditions resulted in the formation of mononucleoside analogs 90a,b. The nucleoside 90a was reacted with mesitylnitrile to give the double-headed nucleoside $\mathbf{9 1}$, whereas nucleoside $\mathbf{9 0 b}$ was reacted with phenylazide to give the double-headed nucleoside 92 (Scheme 20) [13].

Lazrek et al. [51] synthesized C-5'-modified double-headed nucleosides 96a-g, where a 1,2,3-triazolo ring acted as the linker between the nucleobase and the sugar moiety. First, seven $N^{9} / N^{1}$-propargylpurine/pyrimidine nucleobases $\mathbf{1 3 b}, \mathbf{4 5}$ and $53 \mathbf{a}-\mathbf{e}$ were synthesized by treating the nucleobases with propargyl bromide in the presence of $\mathrm{K}_{2} \mathrm{CO}_{3}$. Nucleoside 94 was synthesized from thymidine (93) which was first tritylated at the $\mathrm{C}-5^{\prime}$ primary hydroxy position followed by acetylation at the C-3' secondary hydroxy group [61]. Next, detritylation and tosylation of the protected nucleoside $\mathbf{9 4}$ followed by treatment with lithium azide in DMF and saturated methanolic ammonia solution afforded nucleoside $\mathbf{9 5}$. Refluxing of nucleoside $\mathbf{9 5}$ with $\mathbf{1 3 b}, \mathbf{4 5}$ and 53a-e in toluene produced the desired nucleosides 96a-g (Scheme 21) [51].

Shaikh et al. [14] reported the synthesis of double-headed nucleosides where an aromatic moiety or a nucleobase is attached at the C-5' position of the nucleoside. The synthetic methodology started with the $5^{\prime}$-epoxide 97 , which was synthesized from 3'-O-(tert-butyldimethylsilyl)thymidine in three steps, where the oxidation of the C-5'-hydroxy group followed<smiles></smiles>

78<smiles>Nc1ncnc2c1ncn2[C@@H]1C[C@@H](O)[C@H](CO[AsH3])O1</smiles>

80 adenine (sodium salt) DMF, $50-90{ }^{\circ} \mathrm{C}, 30 \mathrm{~min}$ $31 \%$

adenine (sodium salt) DMF, $50-90{ }^{\circ} \mathrm{C}, 30 \mathrm{~min}$ $14 \%$

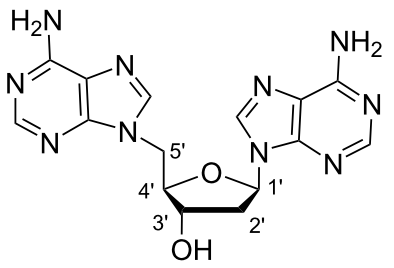

81 


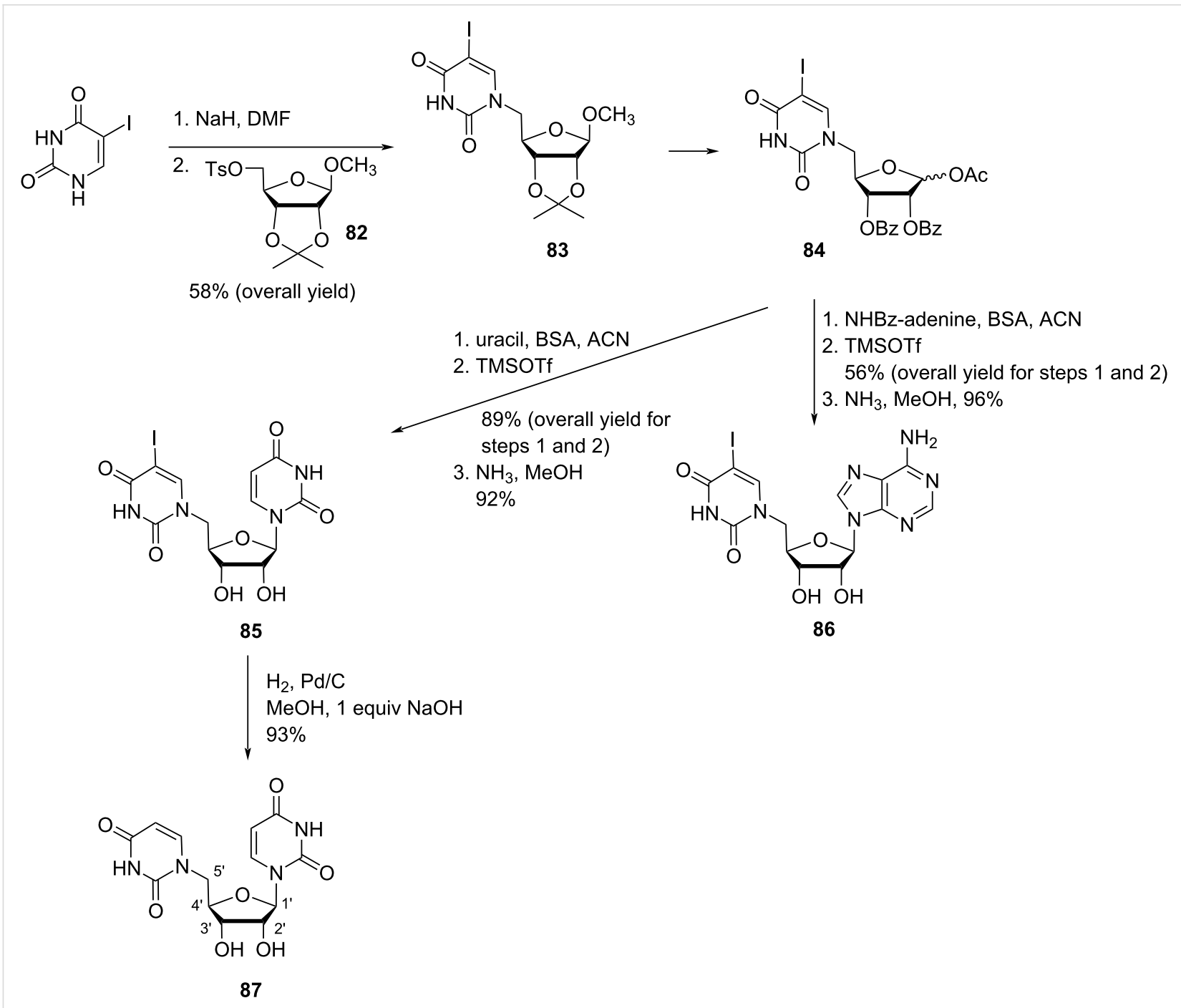

Scheme 19: Synthesis of double-headed nucleosides 85-87 via reversed nucleosides methodology.

by a Wittig reaction with methylenetriphenylphosphorane $\left(\mathrm{Ph}_{3} \mathrm{P}=\mathrm{CH}_{2}\right)$ produced the 5'-methylene derivative [62]. Finally, oxidation with meta-chloroperbenzoic acid (mCPBA) afforded the nucleoside 97. Treatment of the nucleoside 97 with Grignard reagent $\mathrm{PhMgBr}$ in THF produced nucleoside 98, whose secondary hydroxy group was protected by reaction with pixyl chloride to afford the nucleoside $\mathbf{9 9}$. The removal of the tertbutyldimethylsilyl protecting group under standard conditions afforded the double-headed nucleoside 100 (Scheme 22) [14].

Opening of the epoxide ring in nucleoside $\mathbf{9 7}$ with sodium azide in DMF produced nucleoside 101, whose secondary hydroxy group was protected by reaction with pixyl chloride to afford nucleoside 102. The azido nucleoside $\mathbf{1 0 2}$ was a key intermediate, which was used for the synthesis of a variety of 1,2,3-triazolyl-linked double-headed nucleosides. Thus the treatment of azido nucleoside $\mathbf{1 0 2}$ with phenylacetylene in the presence of sodium ascorbate and copper sulfate in a solvent mixture of $t$-BuOH, water and pyridine, followed by the removal of the tert-butyldimethylsilyl protecting group gave nucleoside $\mathbf{1 0 3}$ (Scheme 22) [14]. Under similar reaction conditions, the treatment of nucleoside 102 with $N^{1}$-benzoyl-5-ethynyluracil followed by desilylation produced the double-headed nucleoside 104, whereas the reaction of the azido nucleoside 102 with trimethylsilylacetylene (TMS-acetylene) followed by desilylation produced the nucleoside 105 (Scheme 23) [14].

Christensen et al. [31] synthesized the double-headed nucleoside 5'-(S)-C-(thymin-1-ylmethyl)-3'-O-(tert-butyldimethylsilyl)thymidine (107) by treating the 5 '-olefinic nucleoside 106 with mCPBA in dichloromethane followed by reaction of the resulted product with thymine in the presence of $\mathrm{K}_{2} \mathrm{CO}_{3}$ in hot DMF. The targeted double-headed nucleoside $5^{\prime}-(R)-C$-(thymin1-ylmethyl)-3'-O-(tert-butyldimethyl-silyl)thymidine (108) was 


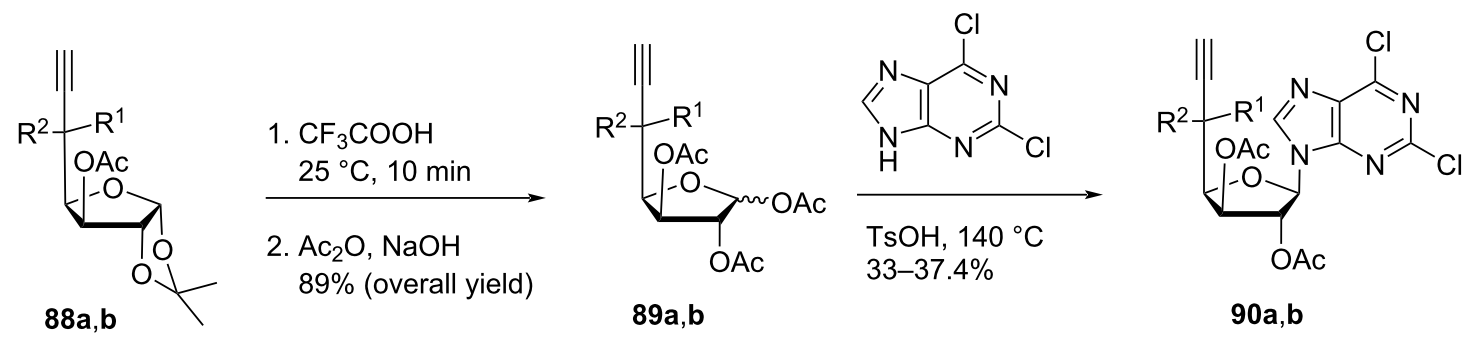

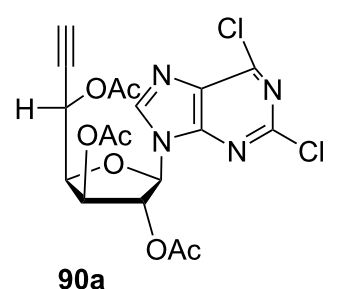
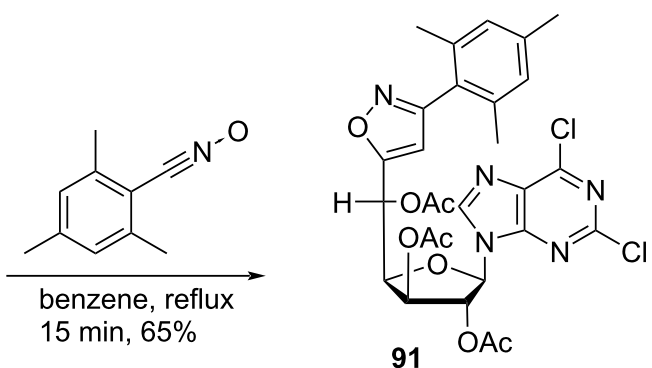

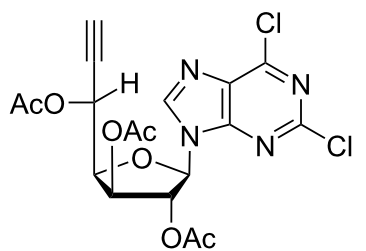

90b

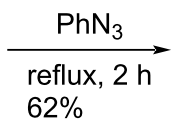
$62 \%$

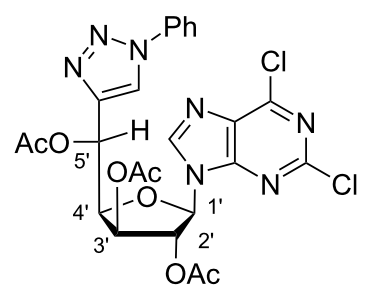

92

Scheme 20: Double-headed nucleosides 91 and $\mathbf{9 2}$ derived from $\omega$-terminal-acetylenic sugar derivatives $\mathbf{9 0 a , b}$.<smiles>Cc1cn(C2OC(O)C(O)C2O)c(=O)[nH]c1=O</smiles>

93

$13 b, 45,53 a-e$

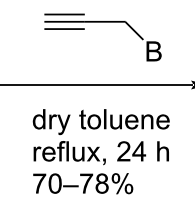<smiles>COC1C(OC(C)=O)C(CO)OC1n1cc(C)c(=O)[nH]c1=O</smiles>

94
1. detritylation

2. $\mathrm{TsCl}, \mathrm{Pyr}$

3. $\mathrm{LiN}_{3}, \mathrm{DMF}, 100^{\circ} \mathrm{C}, 2.5 \mathrm{~h}$

4. sat. $\mathrm{MeOH} / \mathrm{NH}_{3}, 25^{\circ} \mathrm{C}, 18 \mathrm{~h}$ $53 \%$<smiles>Cc1cn(C2CC(O)C(CN)O2)c(=O)[nH]c1=O</smiles>

95

\begin{tabular}{c|c|c|c|c|c|c|c} 
compound & $13 b, 96 a$ & $53 a, 96 b$ & $53 b, 96 c$ & $53 c, 96 d$ & $53 d, 96 e$ & $53 e, 96 f$ & $45,96 g$ \\
\hline B & thymin-1-yl & uracil-1-yl & 5-chlorouracil-1-yl & 5-bromouracil-1-yl & 5-fluorouracil-1-yl & 5-iodouracil-1-yl & adenin-9-yl
\end{tabular}


<smiles>Cc1cn(C2CC(O[Sb](=O)(=O)O)C(C3CO3)(C3CO3)O2)c(=O)[nH]c1=O</smiles>

97

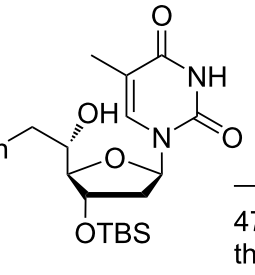

98

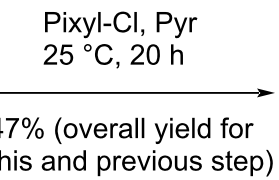

this and previous step)

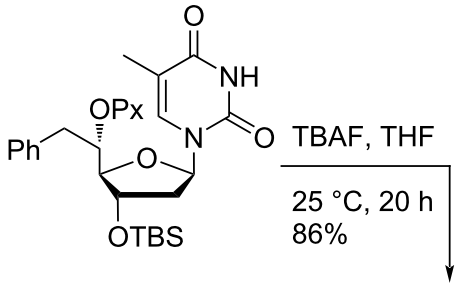

99

$55^{\circ} \mathrm{C}, 3 \mathrm{~h}$

$80 \%$

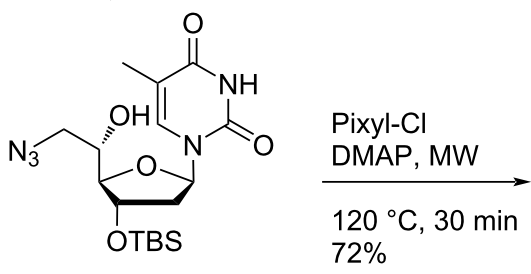

101

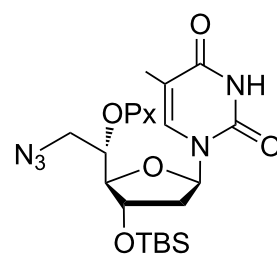

102

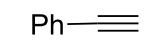

1. sodium ascorbate, $\mathrm{CuSO}_{4}$ $t$ - $\mathrm{BuOH} / \mathrm{H}_{2} \mathrm{O}-\mathrm{Pyr}$ $25{ }^{\circ} \mathrm{C}, 3 \mathrm{~h}, 92 \%$

2. TBAF, THF $25^{\circ} \mathrm{C}, 16 \mathrm{~h}$ $70 \%$
100<smiles>Cc1cn(C2CC(O)C3(Cc4ccccc4)OC2O3)c(=O)[nH]c1=O</smiles>

Scheme 22: Synthesis of double-headed nucleosides 100 and 103.

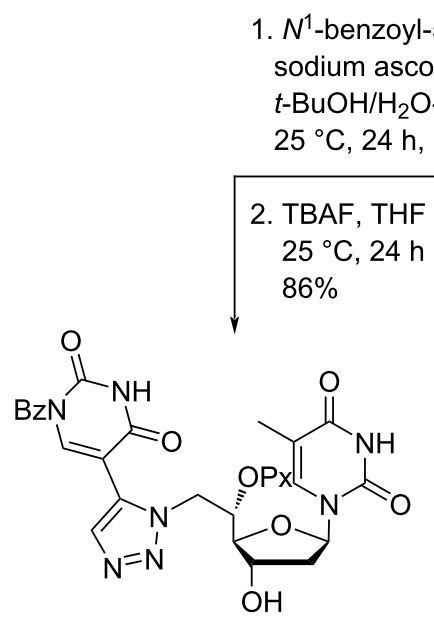

104

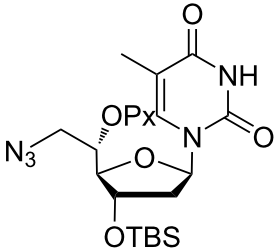

102
1. TMS-acetylene sodium ascorbate, $\mathrm{CuSO}_{4}$ $t$ - $\mathrm{BuOH} / \mathrm{H}_{2} \mathrm{O}-\mathrm{Pyr}$ $25^{\circ} \mathrm{C}, 16 \mathrm{~h}$

2. TBAF, THF $25^{\circ} \mathrm{C}, 55 \mathrm{~h}$ $94 \%$

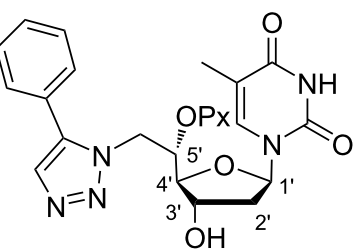

103 


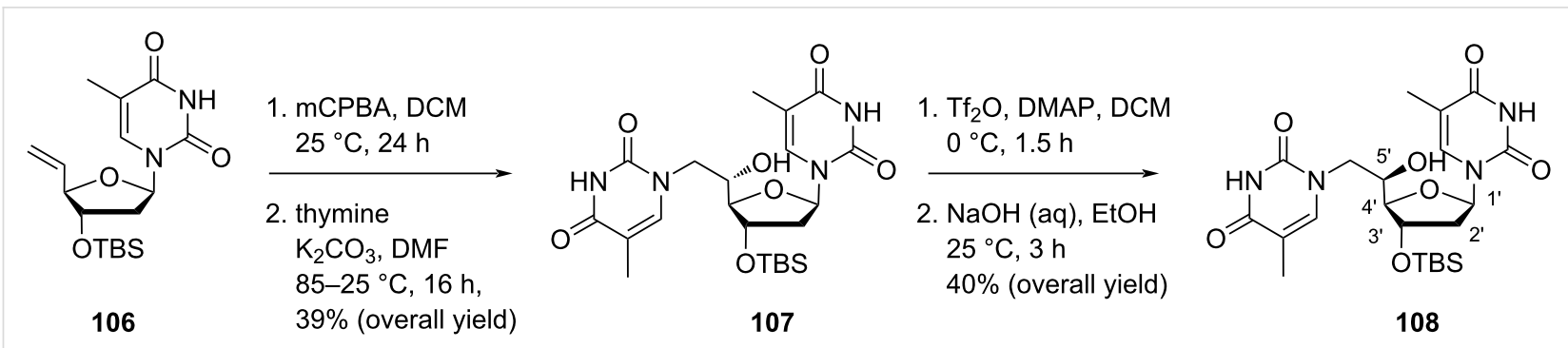

Scheme 24: Synthesis of the double-headed nucleosides 107 and 108.

double-headed nucleosides in two complementary DNA sequences forming a DNA-zipper motif showed a stabilization of the duplex and increased base-base stacking interactions.

Nielsen and co-workers [30,31,65] synthesized double-headed nucleosides 5'-(S)-C-(thymine-1-yl/purin-9-yl)methyl-substituted double-headed nucleosides of thymidine 110-113 with additional nucleobase in the $5^{\prime}(S)$-C-position of thymidine. The double-headed nucleosides 110-113 were synthesized from the olefinic nucleoside 106, which was converted into the epoxide 109 by treatment with mCPBA following the literature procedure [14,62]. The epoxide $\mathbf{1 0 9}$ so formed was reacted with thymine to afford nucleoside $\mathbf{1 0 7}$, which on pixylation and removal of the tert-butyldimethylsilyl-protecting group in the presence of TBAF give double-headed nucleoside $\mathbf{1 1 0}$ (Scheme 25) [30,31,65].

The epoxidation of the olefinic nucleoside $\mathbf{1 0 6}$ with mCPBA followed by reaction with 6 -chloropurine, $N^{6}-(N, N$-dimethyl- formamidine)adenine, or adenine in the presence of $\mathrm{K}_{2} \mathrm{CO}_{3}$ / $\mathrm{NaH}$ in hot DMF afforded the double-headed nucleosides 111-113 (Scheme 26) [30,31,65].

These nucleoside monomers were converted into phosphoramidites and then incorporated into oligonucleotide sequences, followed by thermal hybridization studies that indicated that the $5^{\prime}-(S)$-C-position is ideal for placing an additional nucleobase in the minor groove and interstrand stacking effects decreased with an increase in the length of the linker $[31,65]$.

Nielsen and co-workers [43] synthesized the double-headed nucleoside 5'-O-pixyl-5'(S)-C-(4-(thymin-1-yl-methyl)-1,2,3triazol-1-yl)methylthymidine (114) from 3'-TBS-protected 5'(S)-C-azidomethylthymidine $\mathbf{1 0 2}$ which was synthesized from 3 - $O$-TBS-protected thymidine $[31,65,66]$. The nucleoside azide 102 was then reacted with propargylated thymine via CuAAC reaction, and subsequent removal of TBS group in the presence of TBAF and THF afforded the double-headed nucleoside $\mathbf{1 1 4}$

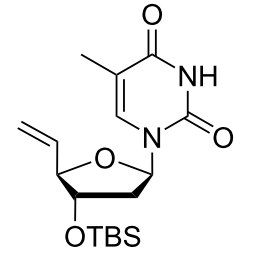

106

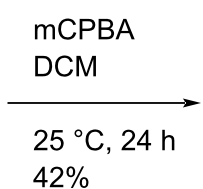

$42 \%$

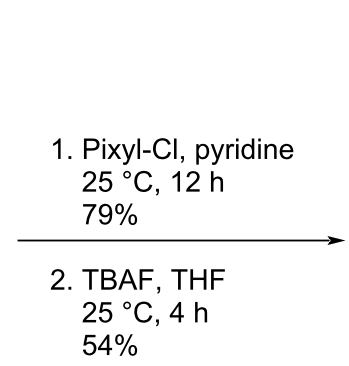<smiles>Cc1cn(C2COCC23CCO3)c(=O)[nH]c1=O</smiles>

109
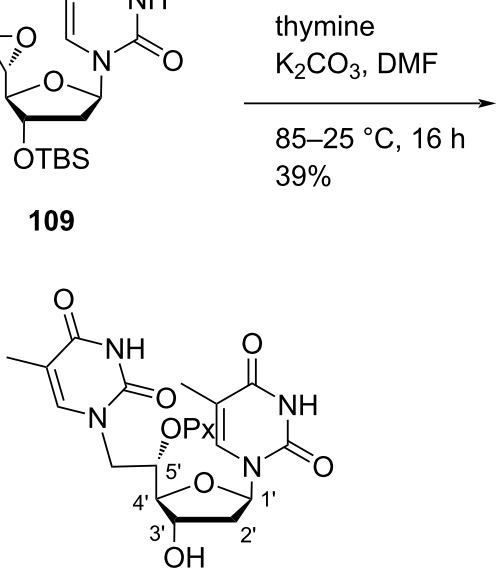

110 
<smiles>Cc1c(C)n(C(O)C(O)Cn2cnc3c(Cl)ncnc32)c(=O)[nH]c1=O</smiles>

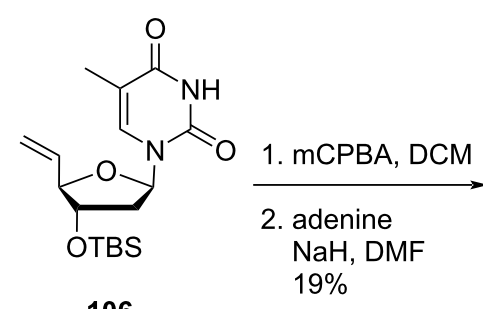

106

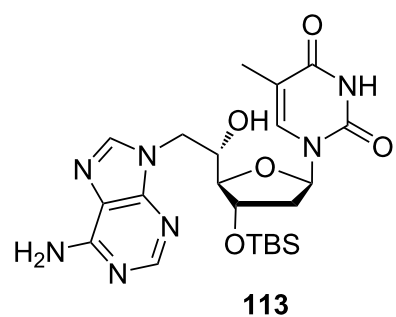

113

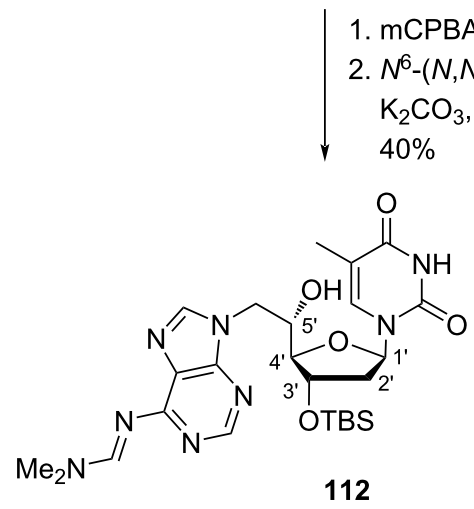

Scheme 26: Synthesis of double-headed nucleosides 111-113 with additional nucleobases in the $5^{\prime}-(S)-C$-position joined through methylene linkers.

where a triazole linker connected the additional thymine to the 5 '-position of thymidine (Scheme 27) [43].

The incorporation of the double-headed nucleoside monomer 114 into oligonucleotides failed to stabilize three-way junctions [43] which is contrary to the double-headed nucleoside $\mathbf{1 1}$ which stabilized three-way junction very efficiently [35].

Nielsen and co-workers [30,65] synthesized the double-headed nucleoside $5^{\prime}$-(S)-C-(2-(thymine-1-yl)ethyl)thymidine (118) with an additional nucleobase at the $5^{\prime}-(S)-C$-position of thymidine. Double-headed nucleoside 118 was synthesized starting from 3'-tert-butyldiphenylsilyl (TBDPS)-protected thymidine
115 which was converted into the pixylated $5^{\prime}(S)$ - $C$-allyl-substituted nucleoside $\mathbf{1 1 6}$ following previously reported procedures [65]. Then, the nucleoside $\mathbf{1 1 6}$ was converted into the primary alcohol 117 by treatment with $\mathrm{OsO}_{4}$ and oxidative cleavage by $\mathrm{NaIO}_{4}$ followed by reduction using $\mathrm{NaBH}_{4}$. The primary alcohol 117 was further converted into nucleoside monomer 118 by introduction of the second nucleobase thymine through Mitsunobu reaction followed by deprotection steps in the presence of TBAF and methanolic ammonia (Scheme 28) $[30,65]$.

The nucleoside monomer 118 was phosphitylated and then incorporated into oligodeoxynucleotides but stabilization in the

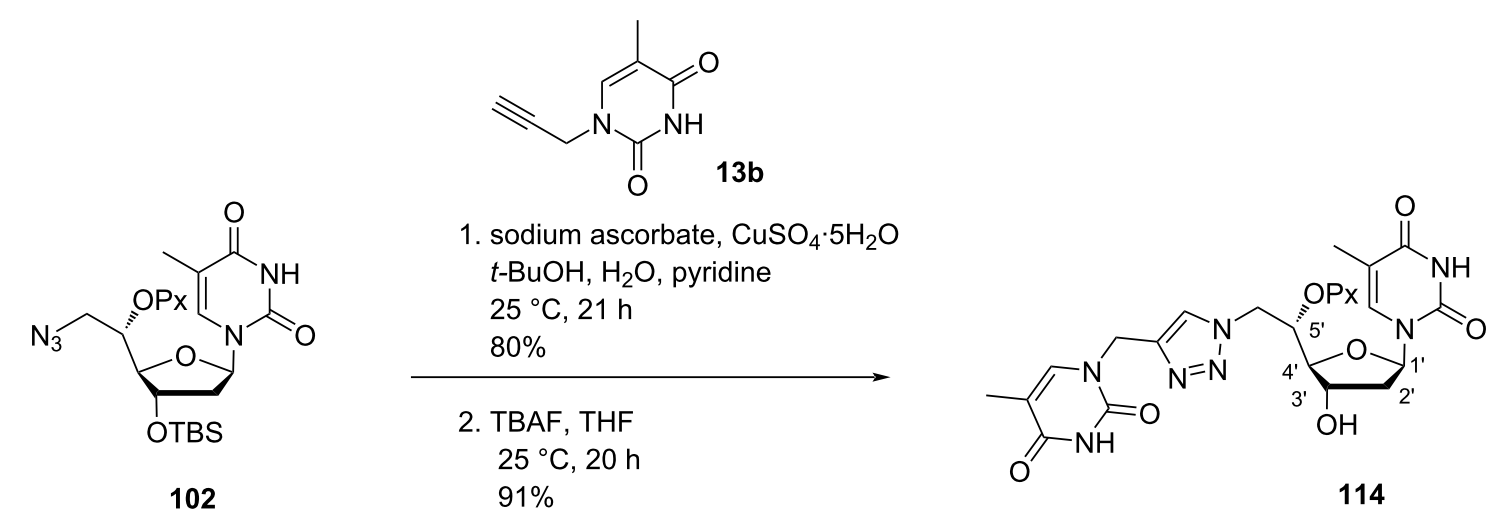

Scheme 27: Synthesis of double-headed nucleoside 114 by click reaction. 




Scheme 28: Synthesis of double-headed nucleosides 118 with an additional nucleobase at the $5^{\prime}$-(S)-C-position.

secondary structures due to additional thymine in combination with the ethylene linker in double-headed nucleoside 118 was not observed because of an increase in the length of the linker which is contrary to the double-headed nucleoside $\mathbf{1 1 0}$ which stabilized secondary structures very well due to shorter length of linker [30,31,65].

\section{Bicyclic double-headed nucleosides}

In this section we have included the double-headed nucleoside monomers, which have a locked nucleic acid type conformation and the additional nucleobase is attached at one of the carbon or nitrogen atoms constituting the bridge (Figure 1). All examples discussed herewith are constituted by furanosyl carbohydrate moiety.

Nielsen and co-workers [67] synthesized the bicyclic doubleheaded nucleoside $(1 R, 4 R / S, 5 R, 6 R, 8 S)$-8-hydroxy-1-hydroxymethyl-4,6-di(uracil-1-yl)-3,7-dioxabicyclo[3.2.1]octane (122), where the additional nucleobase is attached at the bridge between C-2' and C-4'. The synthesis of the aimed nucleoside $\mathbf{1 2 2}$ started from the nucleoside $\mathbf{1 1 9}$ which in turn was synthesized from uridine in six steps following a literature procedure [68]. The olefinic nucleoside 119 was subjected to a $\mathrm{RhCl}_{3}$-mediated allyl rearrangement to give nucleoside $\mathbf{1 2 0}$ as a mixture of $E / Z$ isomers. Further, double bond cleavage of nucleoside $\mathbf{1 2 0}$ followed by benzoylation produced the benzoic acid ester of the hemiacetal analogue $\mathbf{1 2 1}$ which was finally converted into double-headed nucleoside 122 via Vorbrüggen coupling reaction followed by deprotection using methanolic ammonia and TBAF (Scheme 29) [67].
Madsen and co-workers [69] synthesized $N^{2}$-(thymin-1ylacetyl)-, $N^{2}$-( $N^{6}$-benzoyladenin-9-ylacetyl)-, and $N^{2}$-phenylacetyl-substituted double-headed nucleosides of 1-(2'-amino- $2^{\prime}-$ deoxy-5-O-(4,4'-dimethoxytrityl)-2' $-N, 4^{\prime}-C$-methylene- $\beta$-Dribofuranosyl)thymine $\mathbf{1 2 5} \mathbf{a}-\mathbf{c}$ by the reaction of $5^{\prime}-O$ dimethoxytritylated 2 '-amino-LNA thymine nucleoside $\mathbf{1 2 3}$ with acetic acid derivatives, i.e., (thymin-1-yl)acetic acid (124a), $\left(N^{6}\right.$-benzoyladenin-9-yl)acetic acid (124b), and phenylacetic acid (124c) in the presence of $\mathrm{EDC} \cdot \mathrm{HCl}$ as condensation reagent (Scheme 30) [69].

The double-headed nucleoside monomers 125a-c were incorporated into oligodeoxyribonucleotides via phosphoramidite derivatization of the C-3' hydroxy group present in the moiety. The oligonucleotides thus synthesized were found to stabilize the duplex formed with complementary DNA [69].

Nielsen and co-workers $[43,70]$ synthesized the double-headed nucleoside ( $1 S, 3 R, 4 R, 6 R, 7 S)$-7-hydroxy-1-(hydroxymethyl)-3(thymin-1-yl)-6-(4-(thymin-1-ylmethyl)-1,2,3-triazol-1yl)methyl-2,5-dioxabicyclo[2.2.1]heptane (127). The CuAAc reaction of nucleoside azide $\mathbf{1 2 6}$ with propargylated thymine followed by Pd-catalyzed debenzylation under hydrogen atmosphere resulted in the formation of the double-headed nucleoside 127. In nucleoside $\mathbf{1 2 7}$ the triazole ring is attached to the additional thymine moiety via a methylene linker and connected to the 6 '-position of an LNA-thymidine monomer, via another methylene linker (Scheme 31) [43,70]. Interestingly, the incorporation of the double-headed nucleoside 127 into oligonucleotides failed to stabilize three-way junctions [43]. 


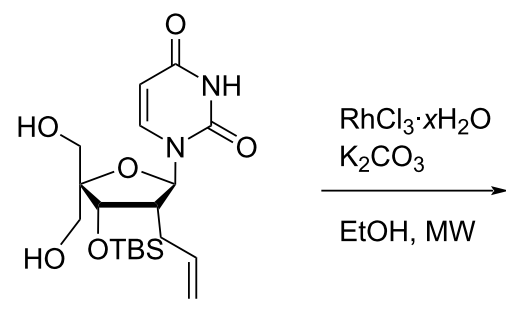

119



120

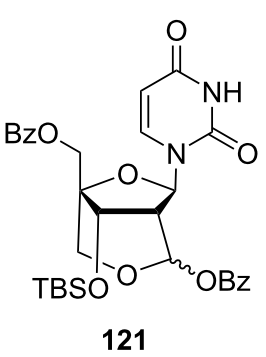

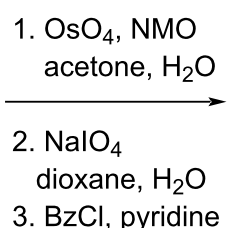

3. $\mathrm{BzCl}$, pyridine

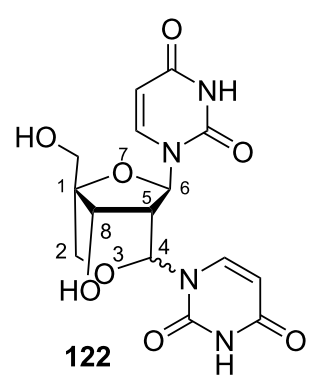

Scheme 29: Synthesis of bicyclic double-headed nucleoside 122.

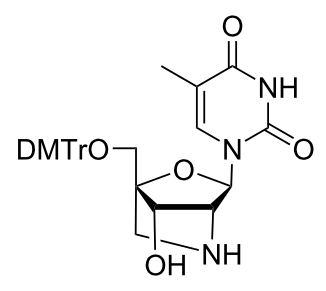

123

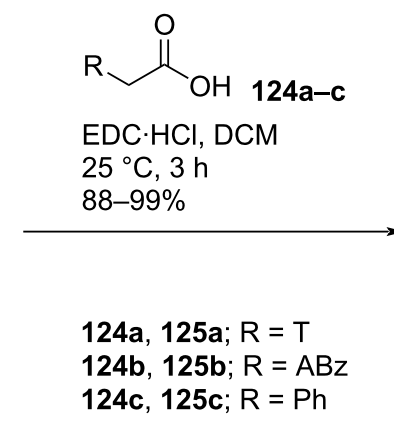

$124 b, 125 b ; R=A B$

124c, 125c; $R=P h$

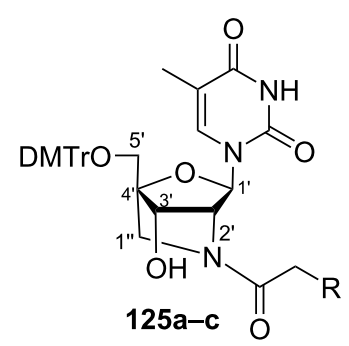

Scheme 30: Synthesis of double-headed nucleosides $125 a-c$ derived from 2 '-amino-LNA.

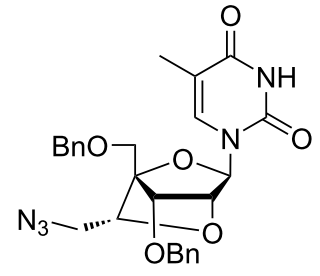

126<smiles>C#CCn1cc(C)c(=O)[nH]c1=O</smiles>

1. sodium ascorbate, $\mathrm{CuSO}_{4} \cdot 5 \mathrm{H}_{2} \mathrm{O}$ $t$ - $\mathrm{BuOH}, \mathrm{H}_{2} \mathrm{O}, \mathrm{MW}$ $130{ }^{\circ} \mathrm{C}, 15 \mathrm{~min}, 95 \%$

2. $\mathrm{H}_{2}, \mathrm{Pd} / \mathrm{C}, \mathrm{EtOH}$ $25^{\circ} \mathrm{C}, 10 \mathrm{~d}$ $67 \%$

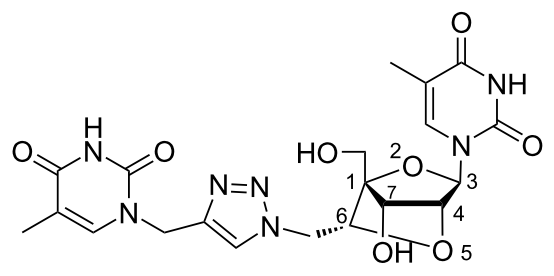

127

Scheme 31: Double-headed nucleoside 127 obtained by click reaction.

\section{Base to base double-headed nucleosides}

Base to base double-headed nucleosides contain an additional natural nucleobase/substituted or unsubstituted phenyl moiety/ polyaromatic moiety/carbocyclic moiety/heterocyclic moiety attached at the $\mathrm{C}-5$ position of the pyrimidine nucleobase (first nucleoside) with or without a linker. The sugar moieties associ- 
ated with these nucleosides were either a 2'-deoxyribofuranosyl moiety or a bicyclic moiety (Figure 1).

Nielsen and co-workers [71] synthesized the double-headed nucleoside 5'-O-(4,4'-dimethoxytrityl)-5-(thymin-1-yl)methyl2 '-deoxyuridine (130) with thymine attached to the C-5 position of 2'-deoxyuridine through a methylene linker. The doubleheaded nucleoside 130 was synthesized from 3',5'-O-diacetyl-5formyl-2'-deoxyuridine (128) which was reduced in the presence of $\mathrm{NaBH}_{4}$ followed by the treatment with $\mathrm{MsCl}$ in pyridine to get the nucleoside salt 129. Next, the pyridinium group was replaced by an $N^{3}$-protected thymine in basic medium followed by removal of the protecting groups and the selective DMTr protection of the C-5'-hydroxy group (Scheme 32) [71]

The double-headed nucleoside monomer 5'-O-(4,4'-dimethoxytrityl)-5-(thymin-1-yl)methyl-2'-deoxyuridine (130) was converted into the corresponding phosphoramidite at the C-3'hydroxy group and then incorporated into oligonucleotides and was found to decrease the thermal stability of the duplexes [71]

Nielsen and co-workers [72] synthesized 5-(3-(thymin-1yl)propyn-1-yl)-, 5-(3-( $N^{4}$-acetylcytosin-1-yl)propyn-1-yl)-, 5-(3-( $N^{6}$-benzoyladenin-9-yl)propyn-1-yl), and 5-(3-( $\left(N^{2}\right.$-isobutyrylguanin-9-yl)-substituted double-headed nucleosides of $5^{\prime}-O$-DMTr-protected $2 '$-deoxyuridine $(\mathbf{1 3 2 a}-\mathbf{d})$ and $5^{\prime}-O$ DMTr-protected $N^{4}$-(dimethylaminomethylene)-2'-deoxycytidine (134a-d) by using Sonogashira cross coupling reaction between the propargylated nucleobases, i.e., 1-propargylthymine, $N^{4}$-acetyl-1-propargylcytosine, $N^{6}$-benzoyl-9-propargyladenine, and $N^{2}$-isobutyryl-9-propargylguanine $(\mathbf{1 3 a}-\mathbf{d})$ and $5^{\prime}-O$ DMTr-protected 5-iodo-2'-deoxyuridine (131) and $\mathrm{N}^{4}$-(dimethylaminomethylene)-2'-deoxycytidine (133) in $65-81 \%$ yield (Scheme 33 ).

The synthesized double-headed nucleosides were phosphitylated and incorporated into oligonucleotides and the melting temperatures were evaluated against unmodified DNA strands. Oligonucleotides with fourteen consecutive incorporations of different double-headed nucleosides were synthesized and the DNA duplexes showed increased stability owing to increased stacking interactions among the nucleobases of the opposite strands [72]. Molecular dynamics simulations demonstrated the exposure of Watson-Crick/Hoogsteen faces of additional nucleobases for their recognition in the major groove.

Sharma and co-workers [73] synthesized 5-(3-(thymin-1yl)phenyl)- and 5-(4-(thymin-1-yl)phenyl)-substituted doubleheaded nucleosides of 5'-O-dimethoxytrityl-2'-deoxyuridine (137, 138) from 5'-O-DMTr-2'-deoxy-5-iodouridine (135). Boronic esters $N^{1}$-(3-(4,4,5,5-tetramethyl-1,3,2-dioxaborolan-2yl)phenyl) and $N^{1}$-(4-(4,4,5,5-tetramethyl-1,3,2-dioxaborolan-2yl)phenyl)-substituted $N^{3}$-benzoylthymine $(\mathbf{1 3 6} \mathbf{a}, \mathbf{b})$ were synthesized by $N^{3}$-benzoylthymine from the procedure given by Gothelf and co-workers [74,75]. The boronic esters (136a,b) were coupled with $5^{\prime}$ - $O$-DMTr-2'-deoxy-5-iodouridine (135) via Suzuki coupling to give double-headed nucleosides 137 and 138 (Scheme 34) [73].

The double-headed nucleosides 5'-O-dimethoxytrityl-5-(3(thymin-1-yl)phenyl)ethynyl-2'-deoxyuridine (140) and $5^{\prime}-O$ dimethoxytrityl-5-(4-(thymin-1-yl)phenyl)ethynyl-2'-deoxyuridine (141) were synthesized via a Sonogashira cross coupling reaction between the $N^{1}$-(3/4-iodophenyl)thymine derivatives 136c and 136d and $2^{\prime}$-deoxy-5-ethynyluridine derivative 139 (Scheme 35) [75].

All four nucleoside monomers were converted into phosphoramidites and then introduced into oligonucleotides. The thermal stability of DNA:DNA and DNA:RNA duplexes was determined and it was found that duplexes with a meta-substitution and a phenylacetylene linker were more stable than the corresponding para-substituted and phenyl-linker containing derivatives.<smiles></smiles>

128
1. $\mathrm{CeCl}_{3}, \mathrm{NaBH}_{4}, \mathrm{THF}$ $0-25{ }^{\circ} \mathrm{C}, 3 \mathrm{~h}, 46 \%$

2. $\mathrm{MsCl}$, pyridine, $\mathrm{DCM}$ 0-25 ${ }^{\circ} \mathrm{C}, 12 \mathrm{~h}$ quantative yield

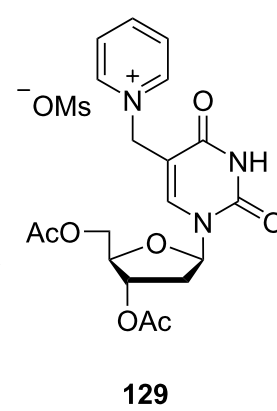<smiles>Cc1c[nH]c(=O)n(C(=O)c2ccccc2)c1=O</smiles>

1. $\mathrm{NaH}, \mathrm{DMF}$ $25^{\circ} \mathrm{C}, 1 \mathrm{~h}, 70 \%$ (overall yield for last three steps)

2. $\mathrm{NH}_{3}, \mathrm{MeOH}, 25^{\circ} \mathrm{C}, 12 \mathrm{~h}$ 3. DMTrCl, pyridine, $25^{\circ} \mathrm{C}$ $12 \mathrm{~h}, 100 \%$ (overall yield for last two steps)

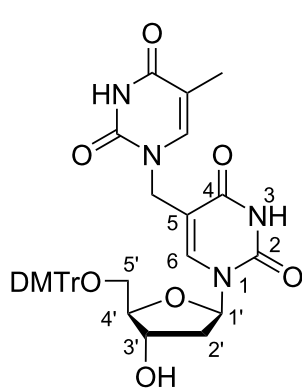

130 
<smiles>O=c1[nH]c(=O)n(C2CC3(O)OC2CC3OO)cc1I</smiles>

131<smiles>[R16]OCC1(CO)OC2=NC(N=CN(C)C)=NC(=O)N1C=C2I</smiles>

133

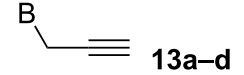

$\mathrm{Pd}\left(\mathrm{PPh}_{3}\right)_{4}, \mathrm{Cul}, \mathrm{Et}_{3} \mathrm{~N}, \mathrm{DMF}$ $25^{\circ} \mathrm{C}, 12-16 \mathrm{~h}$

$65-79 \%$

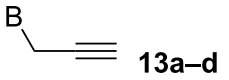

$\mathrm{Pd}\left(\mathrm{PPh}_{3}\right)_{4}, \mathrm{Cul}, \mathrm{Et}_{3} \mathrm{~N}, \mathrm{DMF}$ $25^{\circ} \mathrm{C}, 12-16 \mathrm{~h}$ $65-81 \%$

compounds 13, 132, 134

Scheme 33: Double-headed nucleosides 132a-d and 134a-d synthesized by Sonogashira cross coupling reaction.<smiles></smiles>

137

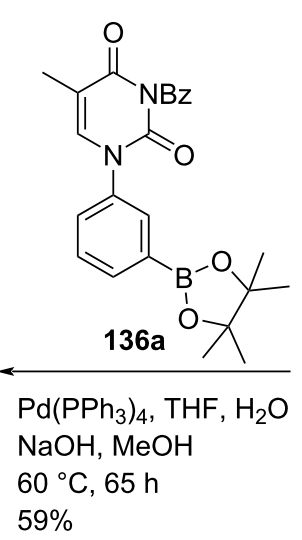

$59 \%$

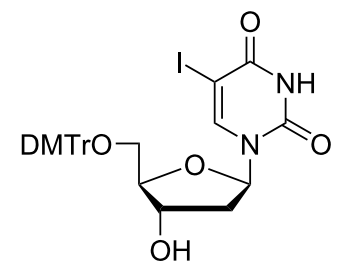

135
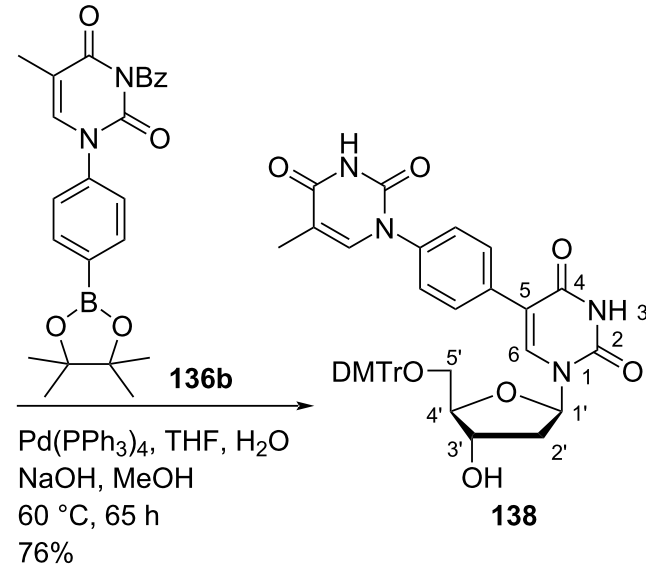

138

Scheme 34: Synthesis of double-headed nucleosides 137 and 138 via Suzuki coupling.

Nielsen and co-workers [71] synthesized the double-headed nucleoside $55^{\prime}-O-\left(4,4^{\prime}\right.$-dimethoxytrityl)-5-(4-(thymin-1yl)methyl-1,2,3-triazol-1-yl)-2'-deoxyuridine (143) with an additional thymine attached to the 5-position of the 2 '-deoxyuri- dine through a triazolomethylene linker. The double-headed nucleoside 143 was synthesized by the CuAAC reaction between 5-azido-5'-O-DMTr-2'-deoxyuridine (142) and 1-propargylthymine (13b) (Scheme 36) [71]. 
<smiles>COCCOC1OC2CC1OC2COC</smiles>

140<smiles>Cc1cn(-c2cccc(I)c2)c(=O)n(C(=O)c2ccccc2)c1=O</smiles>

1. $\mathrm{Pd}\left(\mathrm{PPh}_{3}\right)_{4}, \mathrm{Cul}$ $\mathrm{Et}_{3} \mathrm{~N}, \mathrm{DMF}$ $25^{\circ} \mathrm{C}, 16 \mathrm{~h}$ $73 \%$

2. $\mathrm{NH}_{3}, \mathrm{MeOH}$ $25^{\circ} \mathrm{C}$, overnight $98 \%$

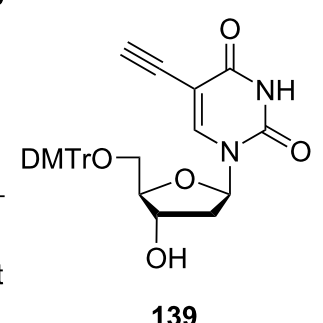

139<smiles>Cc1cn(-c2ccc(I)cc2)c(=O)n(C(=O)OCc2ccccc2)c1=O</smiles>

1. $\mathrm{Pd}\left(\mathrm{PPh}_{3}\right)_{4}, \mathrm{Cul}$ $\mathrm{Et}_{3} \mathrm{~N}, \mathrm{DMF}$ $25^{\circ} \mathrm{C}, 16 \mathrm{~h}$ $88 \%$

2. $\mathrm{NH}_{3}, \mathrm{MeOH}$ $25^{\circ} \mathrm{C}$, overnight $81 \%$

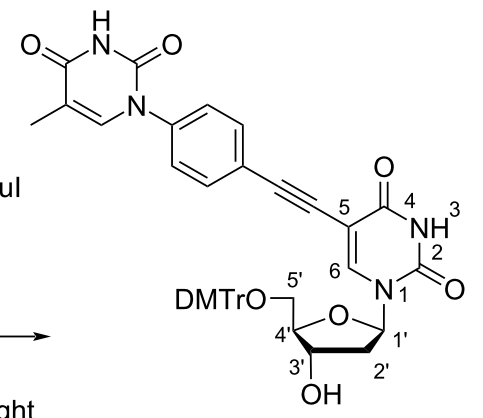

141

Scheme 35: Synthesis of double-headed nucleosides 140 and 141 via Sonogashira cross coupling reaction.<smiles>[R10]OCC1OC(n2cc(C#N)c(=O)[nH]c2=O)CC1O</smiles>

142<smiles>C#CCn1cc(C)c(=O)[nH]c1=O</smiles>

$\mathrm{CuSO}_{4}$, sodium ascorbate $t$ - $\mathrm{BuOH}, \mathrm{H}_{2} \mathrm{O}$, pyridine $25^{\circ} \mathrm{C}, 3 \mathrm{~h}$ $54 \%$

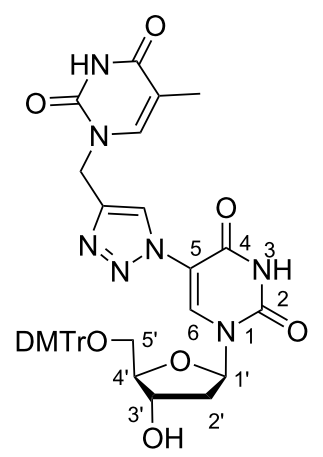

143

Scheme 36: Synthesis of double-headed nucleoside 143

Nielsen and co-workers [71] also synthesized the doubleheaded nucleoside $5^{\prime}-O$-(4,4'-dimethoxytrityl)-6- $\left(\left(N^{6}-(\right.\right.$ dimethylaminomethylidenyl)adenin-9-yl)methyl-2'-deoxypyrrolocytidine (146) which has adenine attached to the 6-position of the pyrrolo-2'-deoxycytidine through a methylene linker. The double-headed nucleoside 146 was synthesized through the Sonogashira coupling reaction between 5'-O-DMTr-5-iodo-2'deoxyuridine (144) and $N^{9}$-propargyladenine (45) followed by treatment with methanolic ammonia and DMA-DMF (Scheme 37) [71].

Both double-headed nucleoside monomers 143 and 146 were phosphoramidated at the C-3' hydroxy group and incorporated into oligonucleotides. The synthesized oligonucleotides were found to decrease the thermal stability of the duplexes. However, their potential in triplex forming oligonucleotides was also studied which concluded the formation of most stable triplexes with single incorporations of additional pyrimidine nucleobases connected via a propylene linker [71].
Hrdlicka and co-workers [24] synthesized 5-C-alkynyl-functionalized double-headed nucleosides 151a-d starting from LNA uridine diol 147 which in turn was synthesized from diacetone$\alpha$-D-allose following a procedure reported in the literature [76]. LNA uridine diol 147 was reacted with iodine and ceric ammonium nitrate (CAN) in acetic acid to afford the nucleoside 148. Nucleoside 148 was then $5^{\prime}$ - $O$-dimethoxytritylated in the presence of DMTrCl (4,4'-dimethoxytrityl chloride) and pyridine. The 5'-O-dimethoxytritylated nucleoside 149 was further coupled with terminal alkynes 150a-d under Sonogashira conditions to afford the double-headed nucleosides 151a-d (Scheme 38) [24].

Hrdlicka and co-workers [24] also synthesized 5-C-triazolylfunctionalized double-headed nucleosides 154a,b starting from 5-C-ethynyl-functionalized LNA uridine 152. The LNA uridine 152 was reacted with 1 -azidopyrene (153a) and 1-azidomethylpyrene (153b) separately under copper-catalyzed alkyne azide cycloaddition (CuAAC) reaction conditions to yield the 

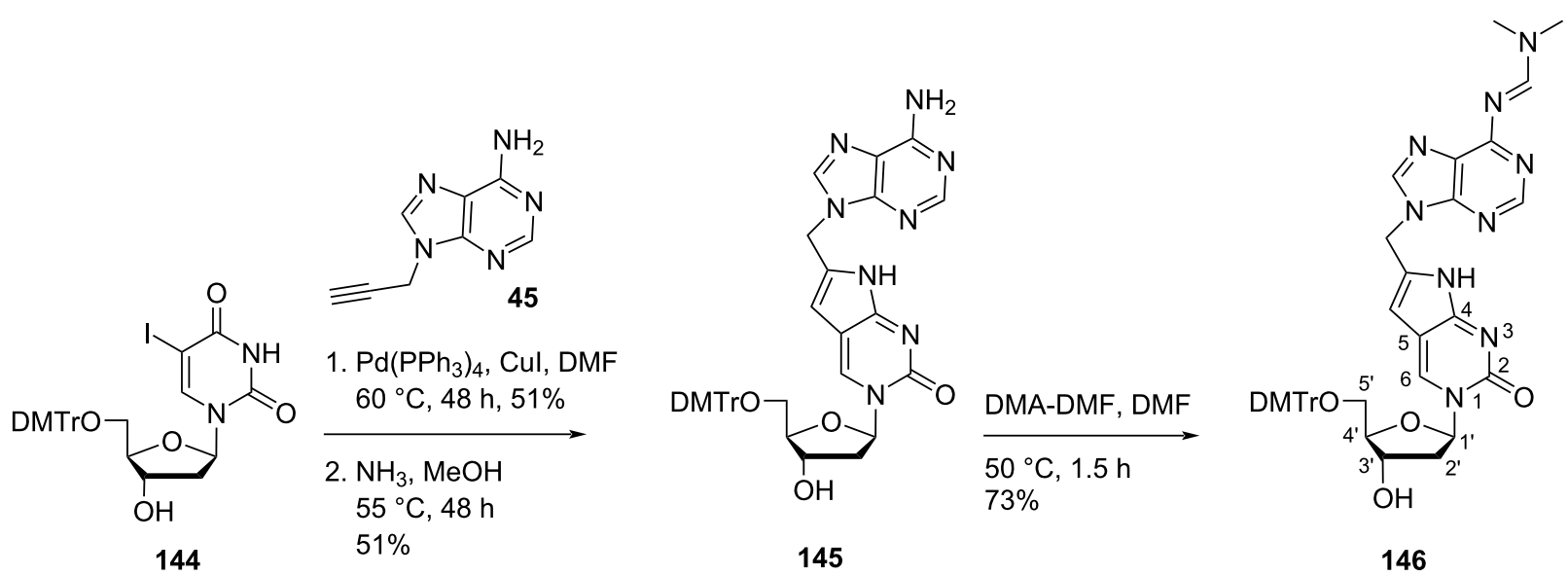

145

146<smiles>O=c1ccn(C2OC3(O)OC2OCC3O)c(=O)[nH]1</smiles>

147

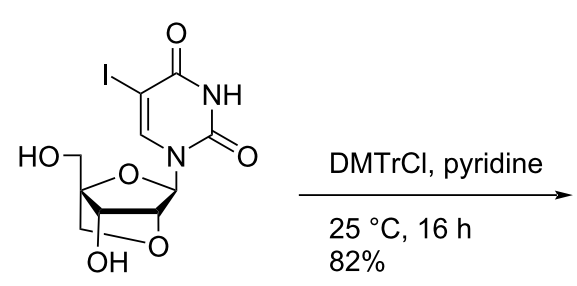

148

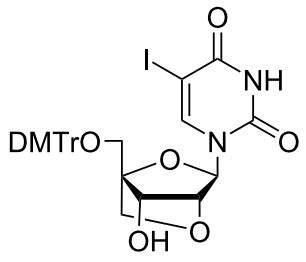

149

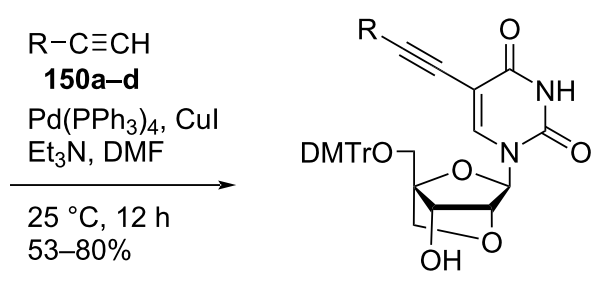

151a-d

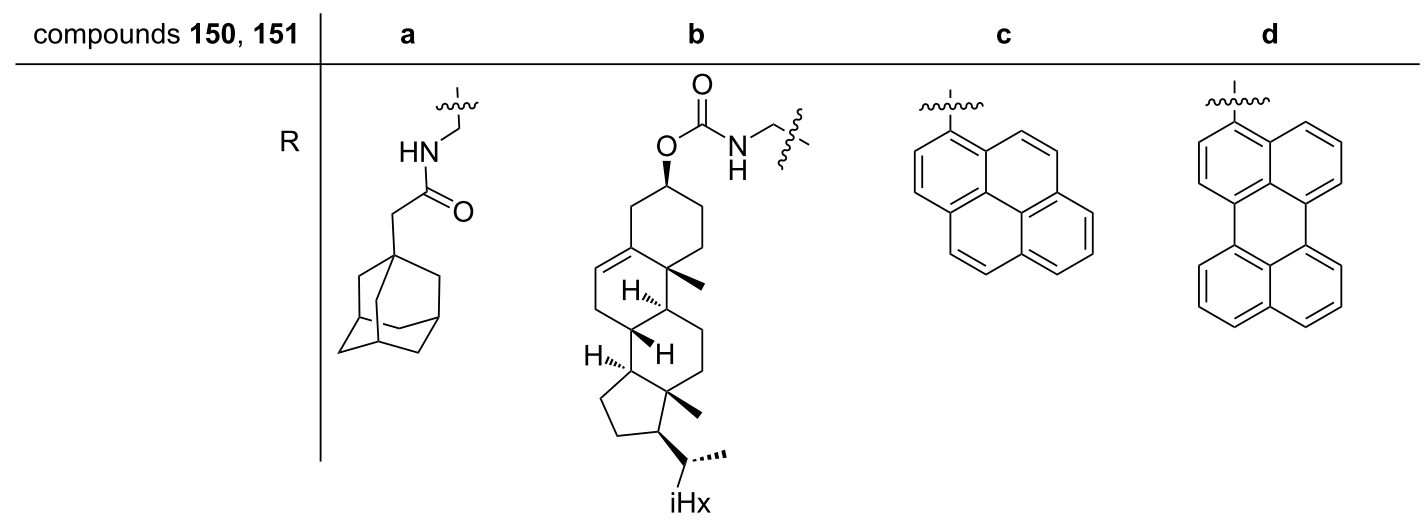


double-headed nucleosides $\mathbf{1 5 4 a}$ and $\mathbf{1 5 4 b}$, respectively (Scheme 39) [24].

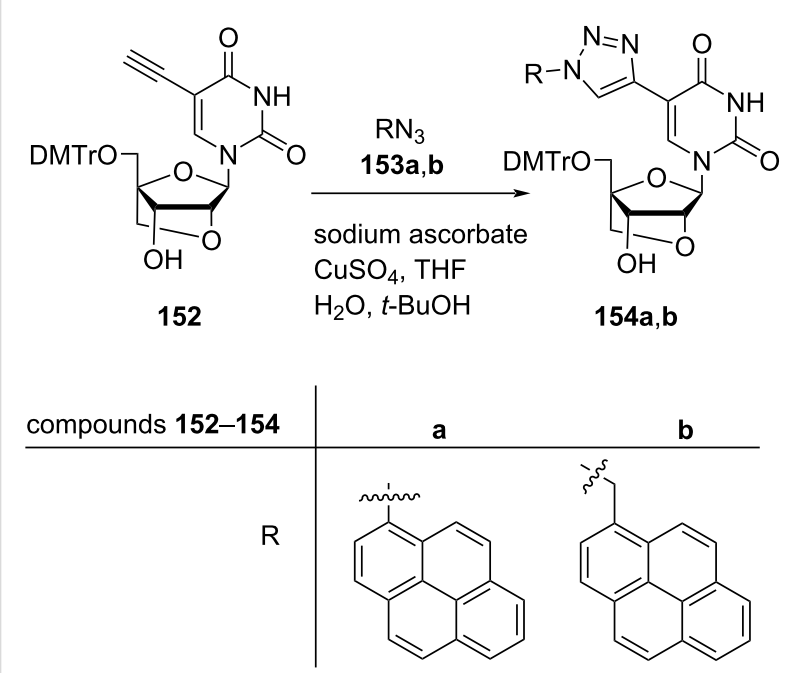

Scheme 39: Synthesis of 5-C-triazolyl-functionalized double-headed nucleosides 154a, b.

The synthesized double-headed nucleosides 151a-d and 154a,b were phosphitylated, incorporated into oligonucleotides and characterized with respect to thermal denaturation, enzymatic stability, and fluorescence properties. The incorporation of the double-headed nucleosides 151a-d and 154a,b into oligo- nucleotides failed to form thermostable duplexes with complementary DNA and RNA strands but exhibited a potential resistance towards 3'-exonuclease. The synthesized double-headed nucleosides 151c,d and 154a,b when incorporated into oligonucleotides enabled fluorescent discrimination of targets with single nucleotide polymorphisms (SNPs) [24].

Nielsen and co-workers [15] synthesized a series of doubleheaded nucleosides 5-(1-phenyl-1H-1,2,3-triazol-4-yl)-2'deoxyuridine (157a), 5-(1-benzyl-1H-1,2,3-triazol-4-yl)-2'deoxyuridine (157b), and 5-(1-pivaloyloxymethyl-1H-1,2,3triazol-4-yl)-2'-deoxyuridine (157c). The synthesis started from 5-ethynyl-2'-deoxyuridine (155) which in turn was synthesized from 5-iodo- 2 -deoxyuridine following literature procedures [77-79]. The terminal alkyne $\mathbf{1 5 5}$ was reacted with bromobenzene and sodium azide under microwave heating in an EtOH/ $\mathrm{H}_{2} \mathrm{O}$ mixture in the presence of copper iodide, sodium ascorbate, and $N, N$-dimethylethylenediamine (156) to afford the double-headed nucleoside 157a. The reaction of the terminal alkyne 155 with benzyl bromide and pivaloyloxymethyl chloride under similar conditions afforded the double-headed nucleosides $\mathbf{1 5 7 b}$ and 157c, respectively (Scheme 40) [15].

The double-headed nucleosides $\mathbf{1 5 7 a - c}$ were introduced into nonamer oligonucleotides by phosphoramidite chemistry [15]. a single incorporation of double-headed nucleosides $157 \mathbf{a}-\mathbf{c}$ into oligonucleotides resulted in the formation of unstable duplexes

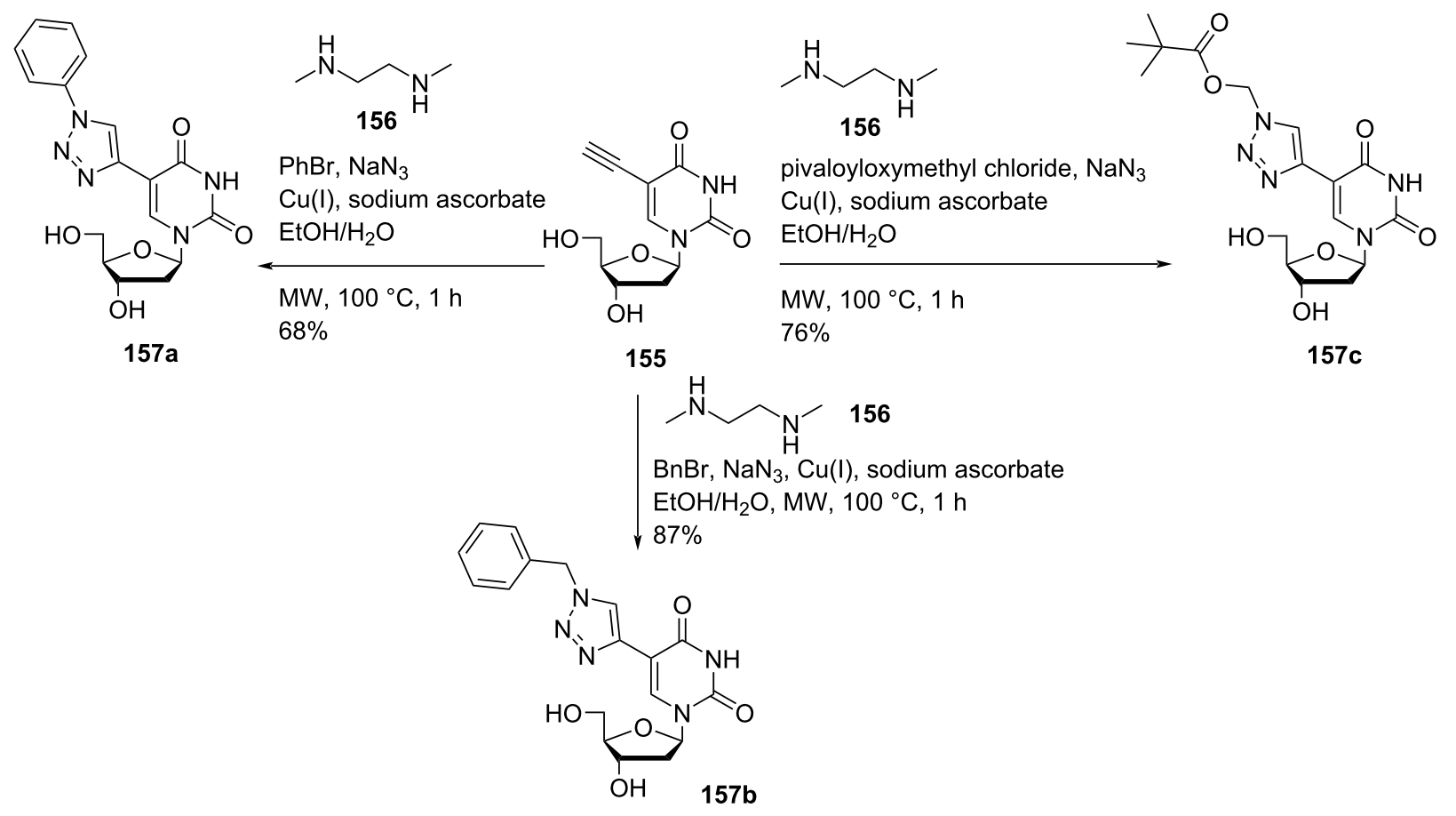


with complementary DNA and RNA strands whereas four consecutive incorporations led to increased duplex stability due to an efficient stacking of heteroaromatic triazoles as revealed by $\mathrm{CD}$ spectroscopy and molecular dynamics simulations $[15,22]$. The double-headed nucleoside 157a was further used for the synthesis of 5-(phenyltriazol)-2'-deoxyuridine-modified 2 '- $O$-methyl mixmer antisense oligonucleotides (AOs). The obtained AOs were investigated for their potential to induce exon skipping in DMD (Duchenne muscular dystrophy) transcript using $H 2 K m d x$ mouse myotubes. It was found that exon-23 skipping potential of oligonucleotide containing 5-(phenyltriazole)-2'-deoxyuridine (157a) building blocks placed distantly was slightly better than oligonucleotides containing the 5-(phenyltriazole)-2'-deoxyuridine (157a) building blocks placed consecutively [80].

Nielsen and co-workers [26] synthesized triazole-containing double-headed nucleosides 159 and 163 by the reaction of $5^{\prime}-O$ dimethoxytritylated nucleoside $\mathbf{1 3 9}$ with tert-butyldimethylsilyl 4-azidophenylether (158) and $N$-(dimethylaminomethylidene)4-azidobenzenesulfonamide (162), respectively under coppercatalyzed alkyne azide cycloaddition (CuAAC) reaction conditions (Scheme 41 and Scheme 42) [26].
The synthesized double-headed nucleosides 159 and 163 were reacted with 2-cyanoethyl- $N, N$-diisopropyl-phosphoramidochloridite in the presence of DIPEA ( $N, N$-diisopropylethylamine) to afford phosphoramidites 160 and 164 which were then incorporated into oligodeoxynucleotides using automated solid phase synthesis. The synthesized oligonucleotides were removed from the solid support by treatment with concentrated aqueous ammonia which resulted in the formation of incorporated monomers 161 and 165 by simultaneous removal of tertbutyldimethylsilyl and amidine protecting groups, respectively (Scheme 41 and Scheme 42) [26].

The incorporation of the double-headed nucleosides 159 and 163 into oligonucleotides resulted in the formation of thermally stable DNA:RNA duplexes due to an efficient $\pi-\pi$ stacking between two or more phenyltriazoles in the major groove. The more stable duplex was obtained when oligonucleotide containing monomer 165 was hybridized with the complementary RNA strand due to the best stacking shown by sulfonamide-substituted phenyltriazoles in the major groove [26,27]. Single incorporations of 5-C-triazolylbenzenesulfonamide-substituted monomer $\mathbf{1 6 5}$ at four positions within the gap region of RNase $\mathrm{H}$ gapmer antisense oligonucleotides (ASOs) reduced wild-type<smiles>C#Cc1cn(C2CC(O)C(CO[N+](=O)[O-])O2)c(=O)[nH]c1=O</smiles>

139

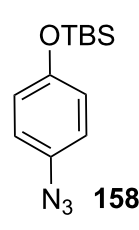

Cul, sodium ascorbate pyridine, $\mathrm{EtOH}, \mathrm{H}_{2} \mathrm{O}$

$25^{\circ} \mathrm{C}, 14 \mathrm{~h}$ $78 \%$<smiles>CCCCCC[C](O)CO</smiles>

159

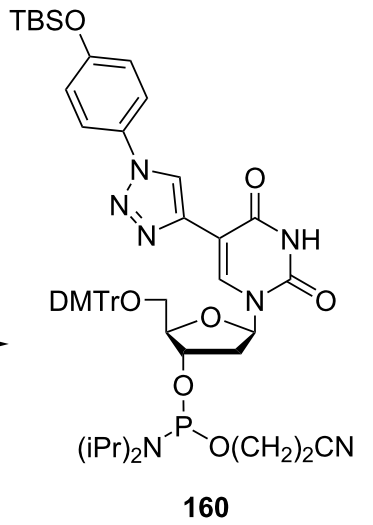

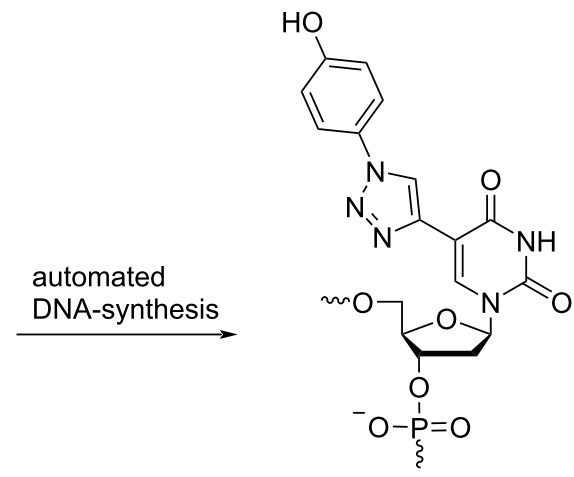

161 


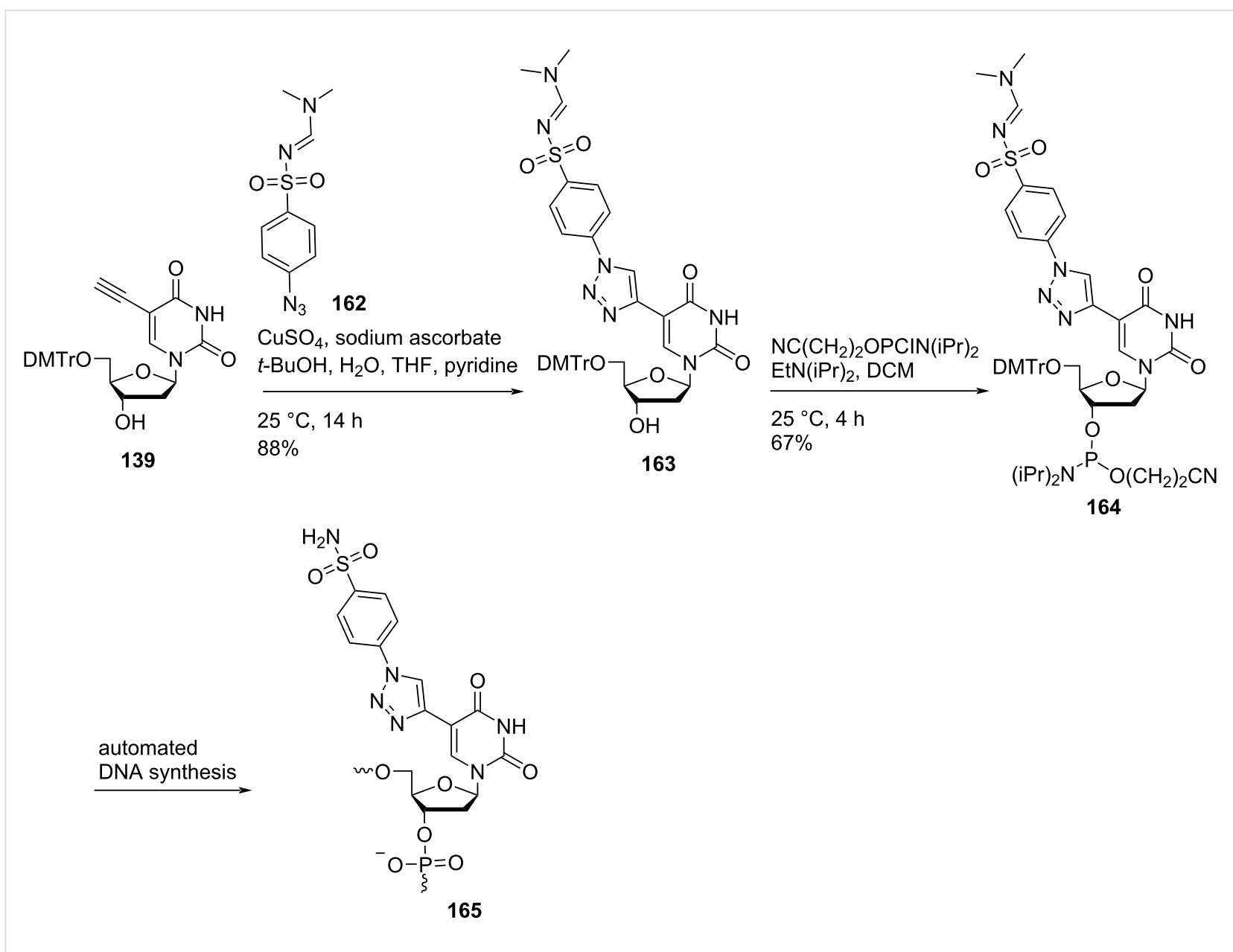

Scheme 42: Synthesis of double-headed nucleoside 163, phosphoramidite 164 and the corresponding nucleotide monomer 165.

and mutant huntingtin mRNA in human patient fibroblasts. A structural model of the catalytic domain of human RNase $\mathrm{H}$ bound to ASO:RNA heteroduplexes was created which was utilized for explaining the activity and selectivity observations in cells and in the biochemical assays [81].

Sharma and co-workers [27] synthesized the double-headed nucleoside 167 by reacting 5'-O-dimethoxytritylated nucleoside 139 with $N$-(dimethylaminomethylidene)-3-azidobenzenesulfonamide (166) under copper-catalyzed alkyne-azide cycloaddition (CuAAC) reaction conditions (Scheme 43). The synthesized double-headed nucleoside $\mathbf{1 6 7}$ was further reacted with 2-cyanoethyl- $N, N$-diisopropyl-phosphoramidochloridite in the presence of DIPEA to afford phosphoramidite 168 which was then incorporated into oligodeoxynucleotides using automated solid phase synthesis. The synthesized oligonucleotides were removed from the solid support by treatment with concentrated aqueous ammonia which resulted in the formation of incorporated monomer 169 by removal of the amidine protection (Scheme 43) [27].
Sharma and co-workers [27] also synthesized double-headed nucleosides 171 and 175 by the Sonogashira coupling of 5'-Odimethoxytritylated alkyne 139 with $N$-(dimethylaminomethylidene)-4-iodobenzenesulfonamide (170) and $N$-(dimethylaminomethylidene)-3-iodobenzenesulfonamide (174), respectively (Scheme 44 and Scheme 45).

The synthesized double-headed nucleosides 171 and 175 were reacted with 2-cyanoethyl- $N, N$-diisopropyl-phosphoramidochloridite in the presence of DIPEA to afford phosphoramidites 172 and 176, respectively. The phosphoramidites 172 and 176 were then incorporated into oligonucleotides using automated solid phase synthesis which after removal from the solid support by treatment with concentrated aqueous ammonia resulted in the formation of incorporated monomers 173 and 177, respectively by removal of the amidine protection of sulfonamides (Scheme 44 and Scheme 45) [27]. The doubleheaded nucleoside $\mathbf{1 7 8}$ was also synthesized starting from $55^{\prime}-O$ dimethoxytritylated alkyne $\mathbf{1 3 9}$ under Sonogashira cross coupling reaction conditions (Scheme 46) [28]. 


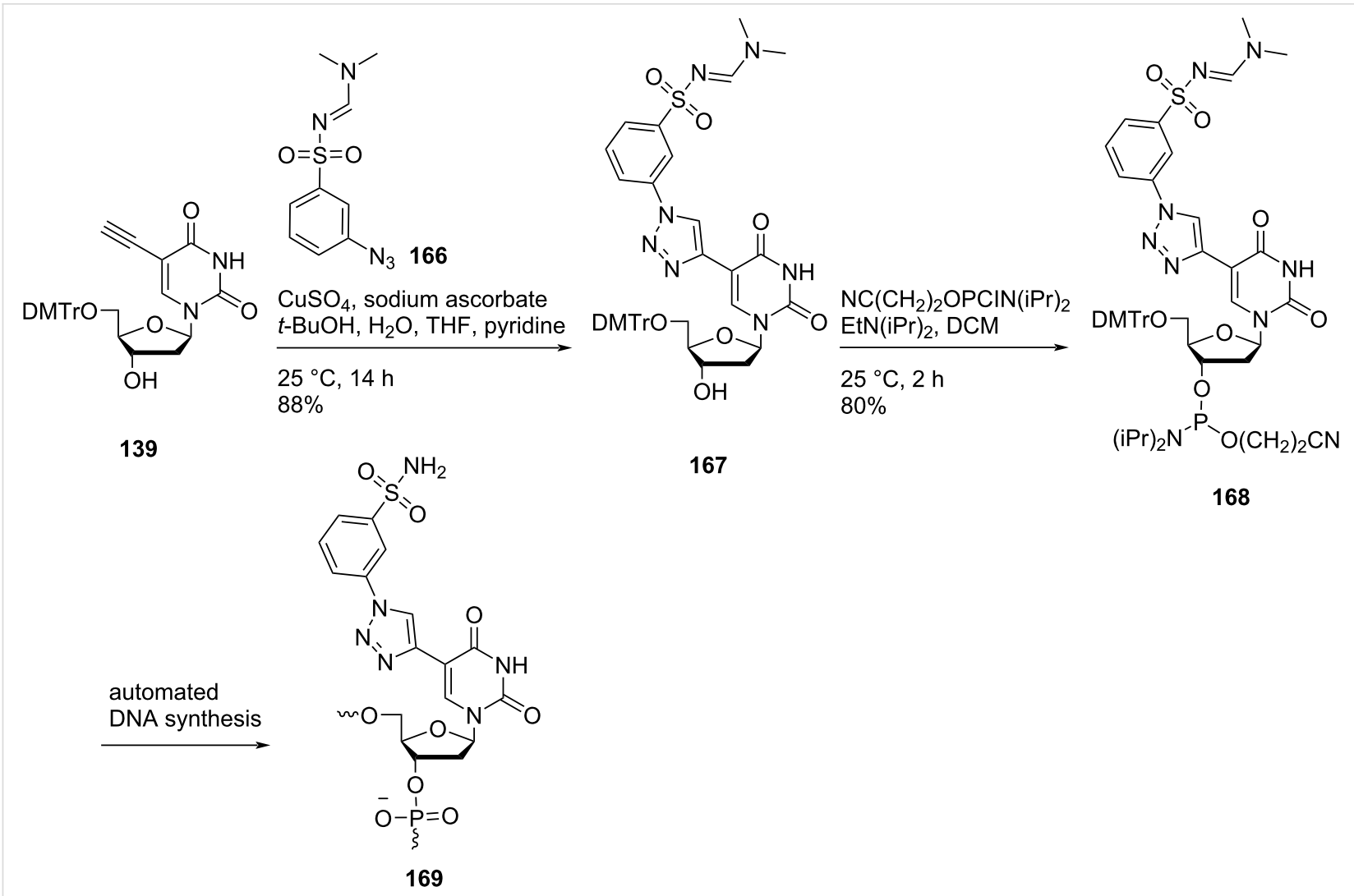

Scheme 43: Synthesis of double-headed nucleoside 167, phosphoramidite 168, and the corresponding nucleotide monomer 169.

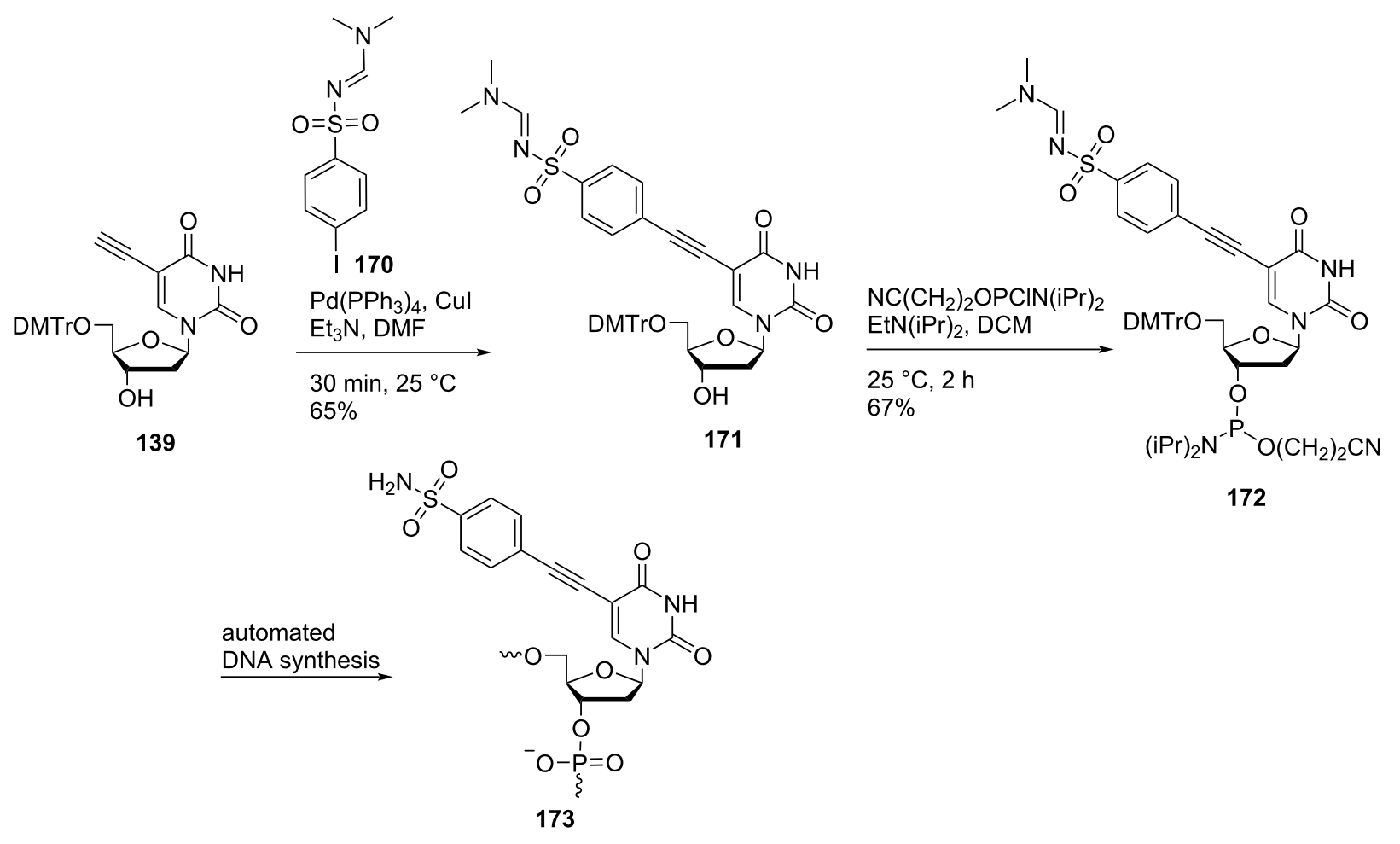

Scheme 44: Synthesis of double-headed nucleoside 171, phosphoramidite 172, and the corresponding nucleotide monomer 173. 


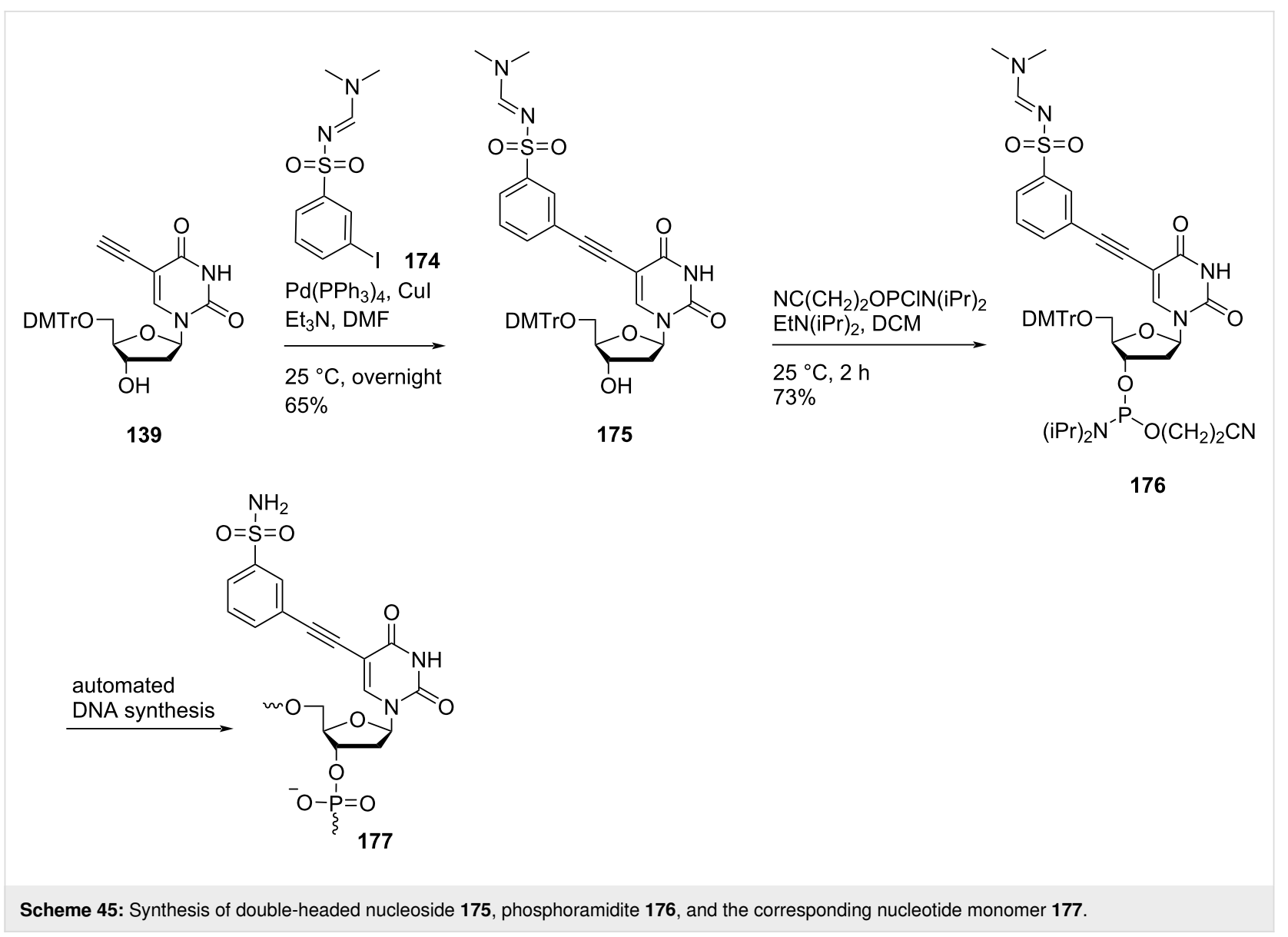

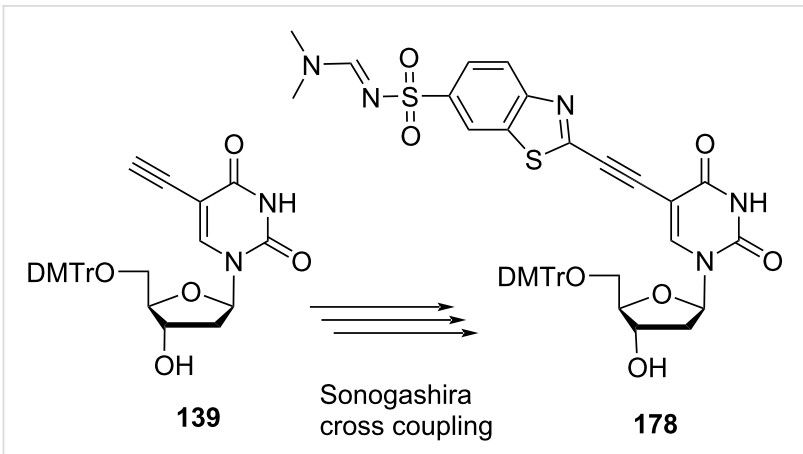

Scheme 46: Synthesis of double-headed nucleoside 178.

The incorporation of the double-headed nucleoside $\mathbf{1 6 7}$ into oligonucleotides resulted in the formation of an equally stable DNA:RNA duplex as in the case of double-headed nucleoside 163 irrespective of the positional orientation of the sulfonamide group due to an efficient $\pi-\pi$ stacking between two or more phenyltriazoles in the major groove [27]. On the other hand, the incorporation of the double-headed nucleosides 171 and 175 into oligonucleotides resulted in the formation of less stable DNA:RNA duplexes because of the poor stacking by the alkynyl group as compared to triazolyl groups in double-headed nucleosides 163 and 167 [27]. The double-headed nucleotide 173 was fully accepted by KOD (kodakaraensis), Phusion, and Klenow DNA polymerases as substrate which resulted in the formation of fully extended DNA. KOD DNA polymerase was found to be the best enzyme to produce DNA containing the double-headed nucleotide $\mathbf{1 7 3}$ in good yield and Phusion DNA polymerase amplified the template containing double-headed nucleotide 173 efficiently by PCR (polymerase chain reaction) [82].

Nielsen and co-workers [22] synthesized the double-headed nucleoside 181 by Suzuki-Miyaura cross coupling reaction of 5-iodo-2'-deoxycytidine (179) with 5-phenylfuran-2-boronic acid pinacol ester $(\mathbf{1 8 0})$ in the presence of $\mathrm{Pd}\left(\mathrm{PPh}_{3}\right)_{4}$ and $\mathrm{NaOH}$ (Scheme 47).

They also synthesized the double-headed nucleoside 183 by $\mathrm{K}_{3} \mathrm{PO}_{4}$-mediated [83] Suzuki-Miyaura cross coupling reaction of 5-iodo-2'-deoxycytidine (179) with pyrazole MIDA $(N$-methyliminodiacetic acid) boronate $\mathbf{1 8 2}$ which in turn was synthesized by sydnone-alkyne cycloaddition reaction between ethynylboronic acid MIDA ester and $N$-phenylsydnone (Scheme 47) [22]. 




181

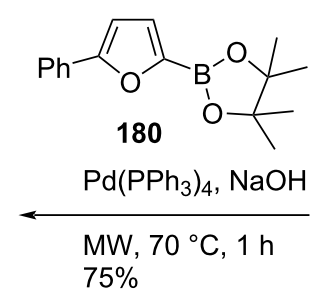<smiles>Nc1cc(=O)n(C2CC(O)C(CO)O2)cc1I</smiles>

179

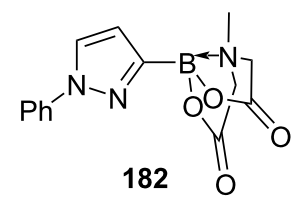

$\mathrm{Pd}\left(\mathrm{PPh}_{3}\right)_{4}, \mathrm{~K}_{3} \mathrm{PO}_{4}$ DMF, $\mathrm{H}_{2} \mathrm{O}$

$60^{\circ} \mathrm{C}, 48 \mathrm{~h}$

$80 \%$

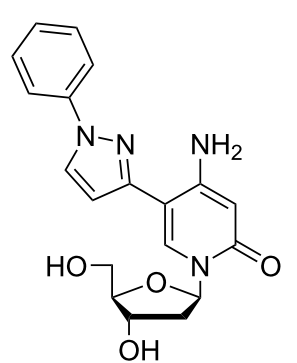

183

Scheme 47: Synthesis of the double-headed nucleosides 181 and 183.

The double-headed nucleoside $\mathbf{1 8 3}$ was also synthesized from 5-ethynyl-2'-deoxycytidine (184) which was first converted into 3',5'-bis-O-(tert-butyldimethylsilyl)-5-ethynyl-2'-deoxycytidine (185). The protected nucleoside 185 was reacted with $N$-phenylsydnone (186) via thermal $[2+3]$ sydnone-alkyne cycloaddition [84] to afford the double-headed nucleoside $\mathbf{1 8 3}$ (Scheme 48) [22].

Nielsen and co-workers [22] also synthesized the doubleheaded nucleoside $\mathbf{1 8 8}$ via thermal [2+3] sydnone-alkyne cycloaddition reaction between $3^{\prime}, 5^{\prime}$-bis-O-(tert-butyldimethylsilyl)-5-ethynyl-2'-deoxyuridine (187) and $N$-phenylsydnone (186) (Scheme 49).
The incorporation of the double-headed nucleosides 181 and 183 multiple times into oligonucleotides resulted in the formation of stable DNA:RNA duplexes due to the perfect stacking of the aromatic moieties in the major groove of the duplex [22]. The double-headed nucleoside 183 containing a phenylpyrazole moiety exhibited better $\pi-\pi$ stacking interactions in the major groove with itself and with an adjacent double-headed nucleoside (157a) incorporated as compared to the doubleheaded nucleoside 181 containing a flexible phenylfuran moiety. There was not any change in the geometry of the duplexes observed upon introduction of double-headed nucleosides 181 and 183 as revealed by CD spectroscopy and molecular modeling. The synthesized oligonucleotides containing<smiles>C#Cc1cn(C2CC(O)C(O)C2O)c(=O)cc1N</smiles>

184 $95 \%$
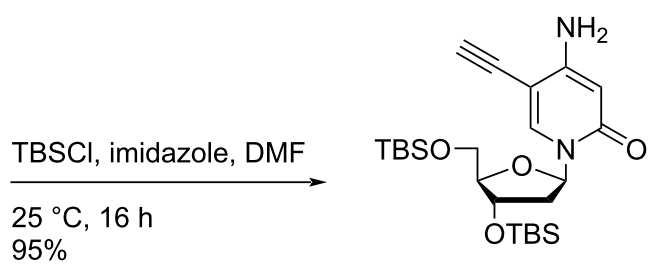

185<smiles></smiles>

1. 1,2-dichlorobenzene $\mathrm{MW}, 180^{\circ} \mathrm{C}, 4 \mathrm{~h}$

2. TBAF, THF $25{ }^{\circ} \mathrm{C}, 1 \mathrm{~h}$ $29 \%$ (overall yield)

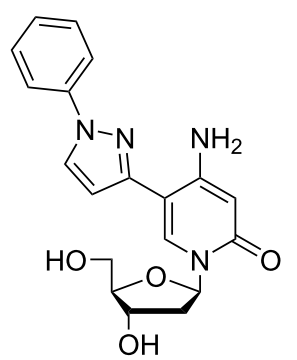

183

Scheme 48: Alternative synthesis of the double-headed nucleoside 183.<smiles></smiles>

155

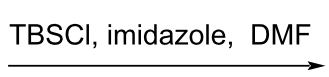

$25^{\circ} \mathrm{C}, 4 \mathrm{~h}$ quantitative



187
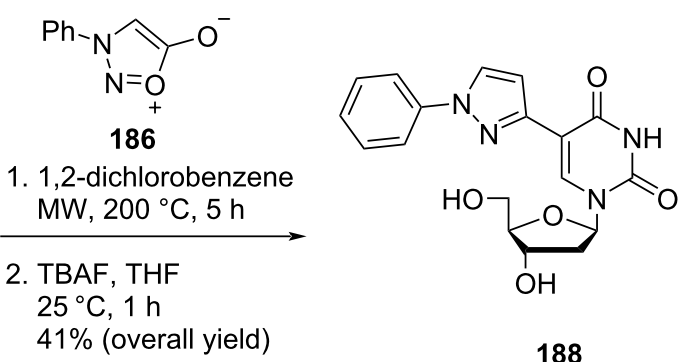

188 
consecutive triazole-functionalized double-headed nucleosides 183 and 157a were found to form highly stable duplexes due to a large aromatic overlap of their substituents at the 5-position due to which they can be utilized as a simple tool in high affinity RNA targeting oligonucleotides [22].

Hrdlicka and co-workers [25] synthesized the double-headed nucleosides 190 and 191 starting from $C 5$-ethynyl-5'-O-(4,4'dimethoxytrityl)-2'-deoxyuridine (139) which in turn was synthesized from 5-iodo-2'-deoxyuridine following a procedure reported in the literature [77]. The nucleoside $\mathbf{1 3 9}$ was reacted with 1-azidomethylpyrene (189a) and 1-azidopyrene (189b) under copper-catalyzed alkyne-azide cycloaddition (CuAAC) reaction conditions to afford the double-headed nucleosides 190 and 191, respectively (Scheme 50) [25].

The incorporation of the double-headed nucleoside $\mathbf{1 9 0}$ into oligonucleotides displayed significant hybridization-induced increase in fluorescence emission whereas the double-headed nucleoside 191 allowed for efficient fluorescent discrimination of SNPs (single nucleotide polymorphisms) via a G-specific quenching mechanism when incorporated into oligonucleotides [25].

\section{Pyranosyl double-headed nucleosides}

Synthetic methodologies have been developed for placing the additional nucleobase at various positions in the pyranonucleosides. Here, we have categorized the double-headed pyranosyl nucleoside monomers depending on the point of attachment at the pyranose sugar. The double-headed pyranosyl nucleosides have the nucleobase attached at the C-6' position of the pyranose moiety, either directly or by a methylene linker (Figure 1). Pyranosyl nucleosides where the additional nucleobase is attached at the C-3' position of the pyranosyl moiety through a triazolo-linker have also been synthesized.

Ferrier and Tyler [85] synthesized the double-headed nucleoside 1-[(5S)-2,3,4-tri- $O$-acetyl-5-(2,6-dichloropurin-9-yl)- $\beta$-Dxylopyranosyl]uracil (195) by photobromination of tetra- $O$ acetyl- $\beta$-D-xylopyranose (192) to afford the crystalline product 193 which upon reaction with bis(2,6-dichloropurinyl)mercury in xylene afforded crystalline compound 194. Subsequently, the nucleoside analogue 194 was reacted with $\mathrm{BF}_{3}$. $\mathrm{OEt}_{2}$ followed by reaction with silylated uracil to get the double-headed nucleoside 195 (Scheme 51) [85].

Prasad and co-workers [86] synthesized hexopyranosyl doubleheaded pyrimidine homonucleosides 1-[(6-deoxy-6-(uracil-1yl)- $\beta$-D-glucopyranosyl)methyl]uracil (200a), 1-[(6-deoxy-6(thymin-1-yl)- $\beta$-D-2,3,4-tri- $O$-benzylglucopyranosyl)methyl] thymine (200b) and 1-[(6-deoxy-6-(uracil-1-yl)- $\beta$-Dmannopyranosyl)methyl]uracil (200c) from dihydroxy 2,6anhydro-3,4,5-tri- $O$-benzylheptitols $(\mathbf{1 9 6} \mathbf{a}, \mathbf{b})$ which in turn were synthesized from D-glucose and D-mannose [87]. The benzylated 2,6-anhydroheptitols 196a,b were reacted with tosyl chloride to form the ditosylated compounds $197 \mathbf{a}, \mathbf{b}$ which upon

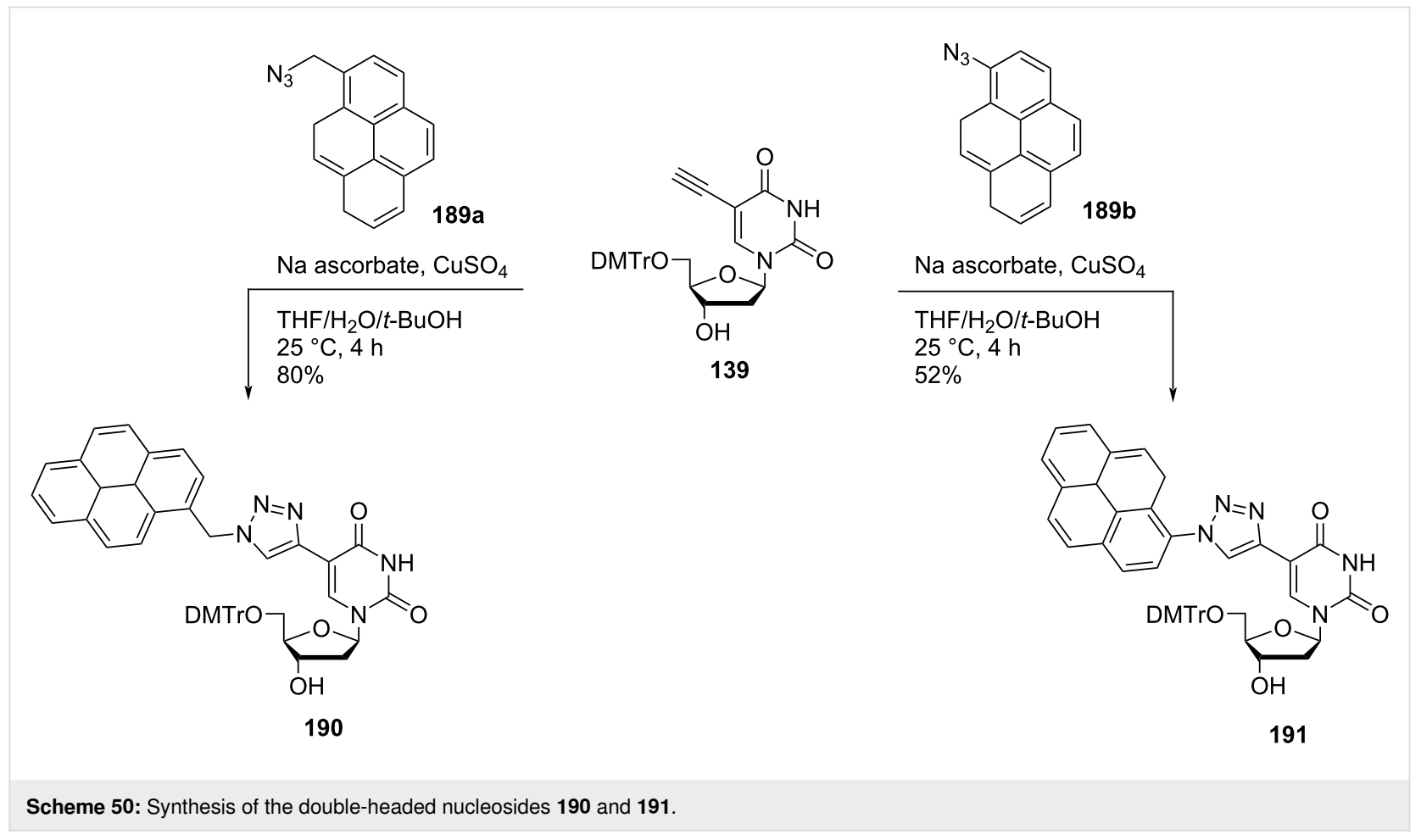



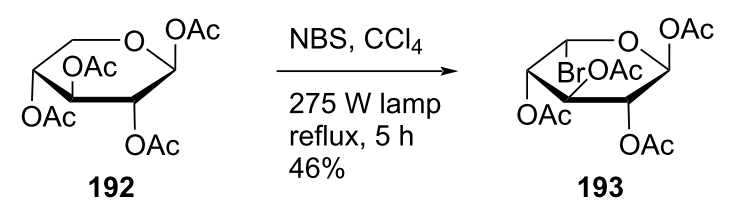

xylene

reflux, $35 \mathrm{~min}$

$32 \%$

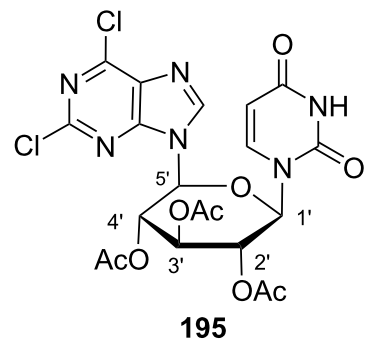

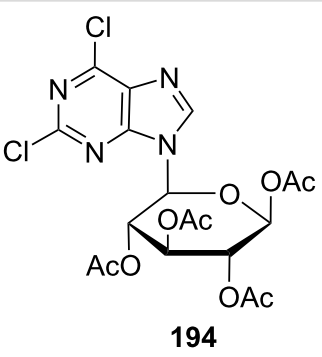

194
1. $\mathrm{BF}_{3} \cdot \mathrm{OEt}_{2}, \mathrm{DCMME}$ 1,2-DCE,
2. bis(trimethylsilyl)uracil mercury(II) cyanide nitromethane
$20^{\circ} \mathrm{C}, 7 \mathrm{~d}$ $30 \%$ (overall yield)

bis(2,6-dichloropurinyl)mercury(II)

$\stackrel{\text { is(2,6-dichloropurinyl)mercury(II) }}{\text { xylene }}$
eflux, 35 min
$2 \%$

Scheme 51: Synthesis of 1-((5S)-2,3,4-tri-O-acetyl-5-(2,6-dichloropurin-9-yl)- $\beta$-D-xylopyranosyl)uracil (195).

reaction with substituted thymine and uracil 198a,b afforded the benzylated double-headed nucleosides 199a-c. Next, debenzylation of the nucleoside monomers 199a-c afforded the final double-headed nucleoside monomers 200a-c. (Scheme 52) [86].
Komiotis and co-workers [37] synthesized 3'-C-(1,4-disubstituted-1,2,3-triazolyl)-substituted double-headed pyranonucleosides 203-210 from 3'-C-ethynyl- $\beta$-D-allopyranonucleoside derivatives 201a-f (Figure 2 ) which in turn were synthesized from 1,2:5,6-di- $O$-isopropylidene- $\alpha$-D-ribohexofuranos-3-ulose [88].

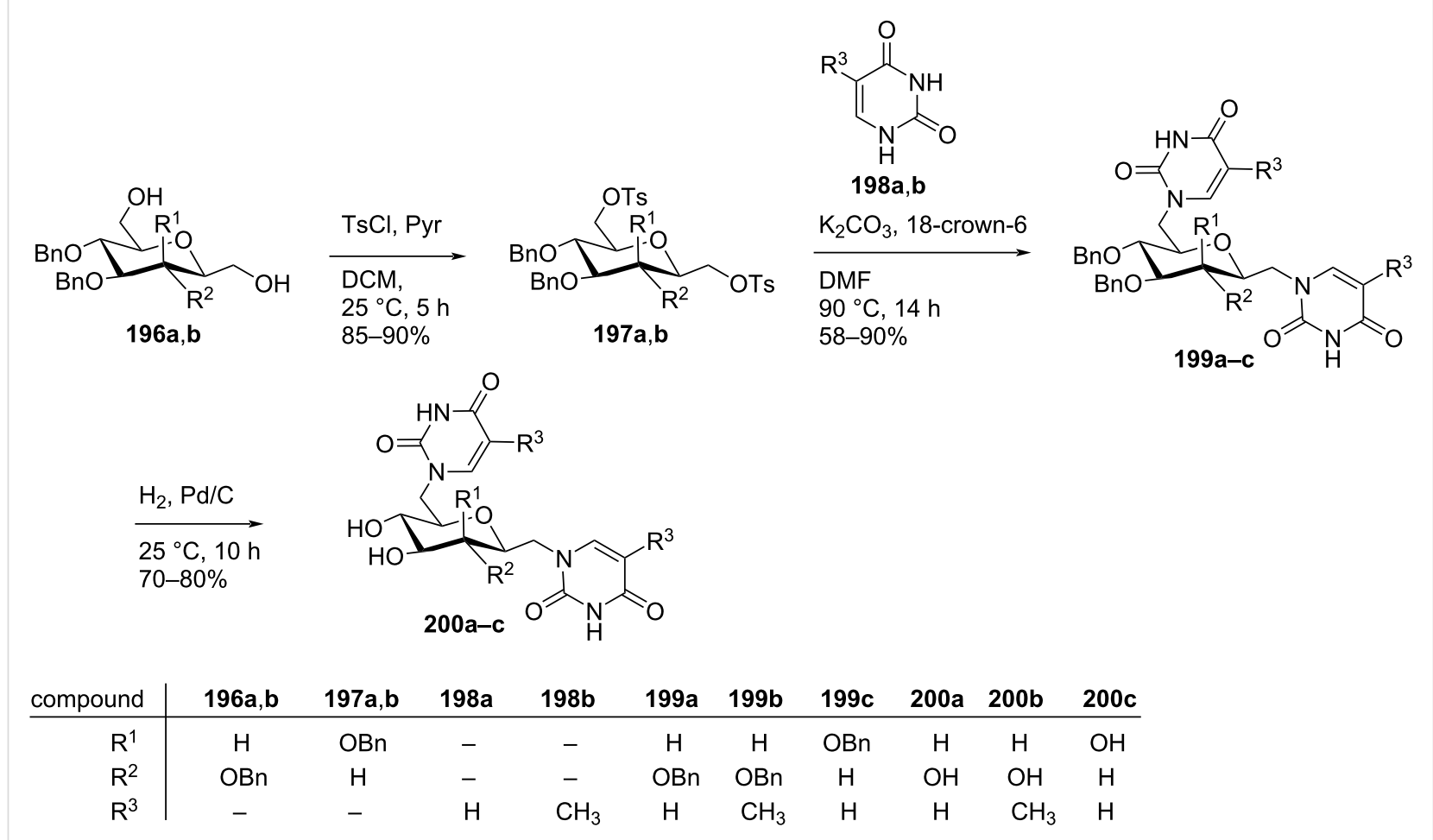




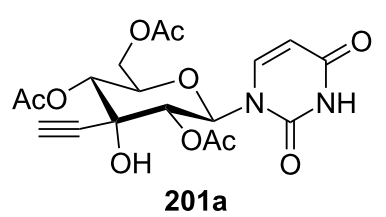

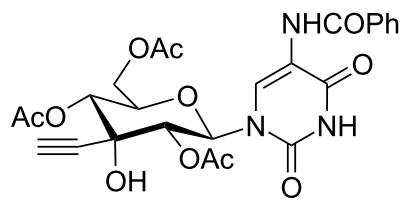

201d

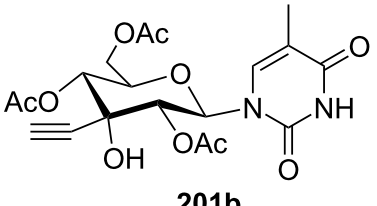

201b

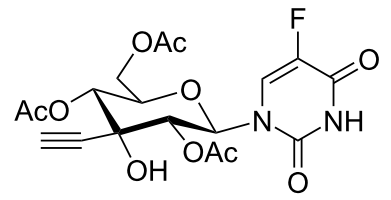

201e

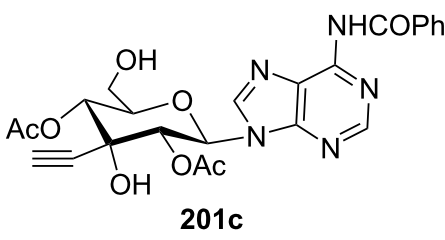

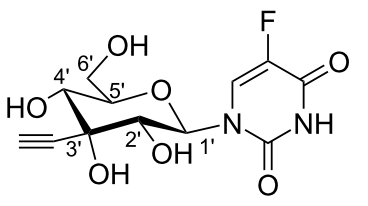

$201 f$

Figure 2: 3'-C-Ethynyl- $\beta$-D-allopyranonucleoside derivatives 201a-f.

The $3^{\prime}$ - $C$-ethynyl-substituted pyranonucleoside derivatives 201a-f were reacted with azidoethyladenine, 5-fluorouracil and thymine 202a-c via copper-catalyzed azide-alkyne cycloaddi- tion $(\mathrm{CuAAC})$ reaction followed by treatment with methanolic ammonia to afford the double-headed nucleosides 203-210 (Scheme 53, Scheme 54, and Scheme 55) [37].

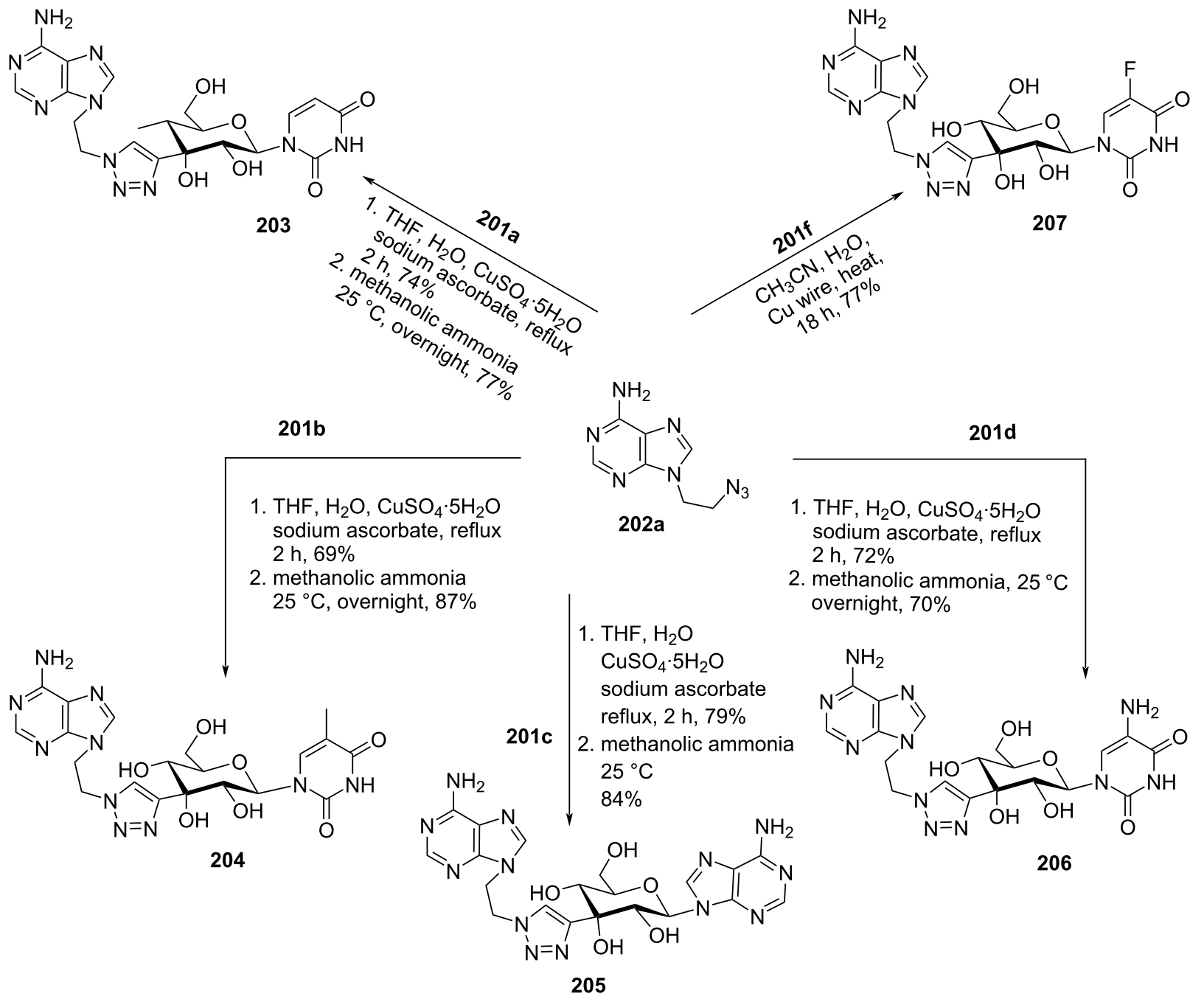




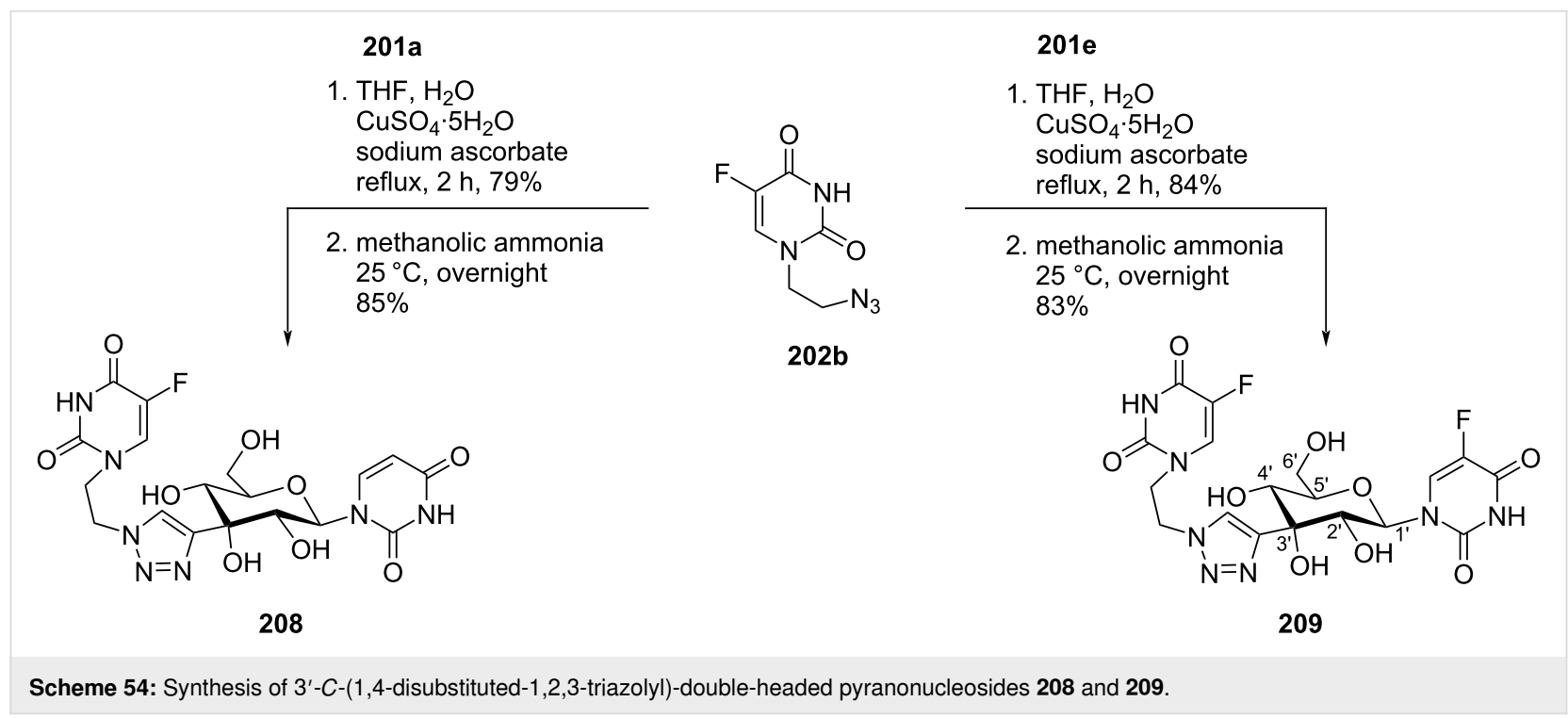

201a<smiles>Cc1cn(CCN)c(=O)[nH]c1=O</smiles>

202c
1. THF, $\mathrm{H}_{2} \mathrm{O}, \mathrm{CuSO}_{4} \cdot 5 \mathrm{H}_{2} \mathrm{O}$ sodium ascorbate, reflux $2 \mathrm{~h}, 67 \%$

2. methanolic ammonia, $25^{\circ} \mathrm{C}$, overnight $86 \%$

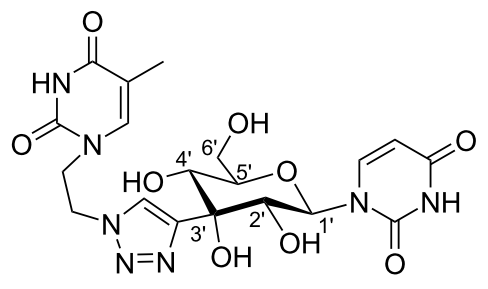

210

Scheme 55: Synthesis of 3'-C-(1,4-disubstituted-1,2,3-triazolyl)-double-headed pyranonucleoside 210.

The double-headed nucleosides 203-210 were evaluated for their antiviral and cytostatic activities, and the nucleosides 204, 206, and 207 showed moderate cytostatic activity against human cervix carcinoma HeLa cells [37].

\section{Acyclic double-headed nucleosides}

In this section, double-headed nucleosides are included that have an acyclic carbohydrate moiety and the heterocyclic moieties/nucleobases are terminally attached at the sugar moiety (Figure 1).

Nielsen and co-workers [89] synthesized four stereoisomers of double-headed acyclic nucleosides 1,4-bis(thymine-1-yl)butane2,3-diols 213a-d starting from either D- or L-2,3-O-isopropylidenethreitol 211a,b. The dihydroxy compounds 211a,b were reacted with $N^{3}$-benzoylthymine under Mitsunobu reaction conditions followed by DMTr protection to give two enantiopure compounds $(2 R, 3 R)-1,4$-bis(thymin-1-yl)-3-O-DMTrbutan-2-ol (212a) and (2S,3S)-1,4-bis(thymin-1-yl)-3-O-DMTrbutan-2-ol (212b). The two compounds upon removal of the DMTr group gave the acyclic double-headed nucleosides
(2R,3R)-1,4-bis(thymine-1-yl)butane-2,3-diol (213b) and (2S,3S)-1,4-bis(thymine-1-yl)butane-2,3-diol (213d). Further, the reaction of the 3-O-DMTr-protected nucleosides 212a,b with mesyl chloride followed by treatment with aq. $\mathrm{NaOH}$ in ethanol afforded the nucleosides $(2 S, 3 R)$-1,4-bis(thymine-1yl)butane-2,3-diol (213a) and (2R,3S)-1,4-bis(thymine-1yl)butane-2,3-diol (213c) (Scheme 56 and Scheme 57) [89].

These double-headed nucleosides when incorporated into oligonucleotides destabilized both DNA and RNA duplexes. However, nucleosides with $2^{\prime}(S)$-configuration were found to destabilize duplexes and bulged motifs to a lesser extent than the other stereoisomers [89].

Nasr [16] synthesized 1,4-bis(9-methyl-1,3,4-oxadiazino[6,5b]indol-2-yl-1-ium) dichloride, 1,4-bis(9-ethyl-1,3,4-oxadiazino[6,5-b]indol-2-yl-1-ium) dichloride, and 1,4-bis(9-acetyl1,3,4-oxadiazino[6,5-b]indol-2-yl-1-ium) dichloride-substituted double-headed nucleosides of 1,2,3,4-tetra- $O$-acetylgalactotetritol 218b-d starting from 1,3-dihydro-2,3-dioxo- $2 \mathrm{H}$ indoles $\mathbf{2 1 4 a - c}$. The indoles were condensed with galactaric 


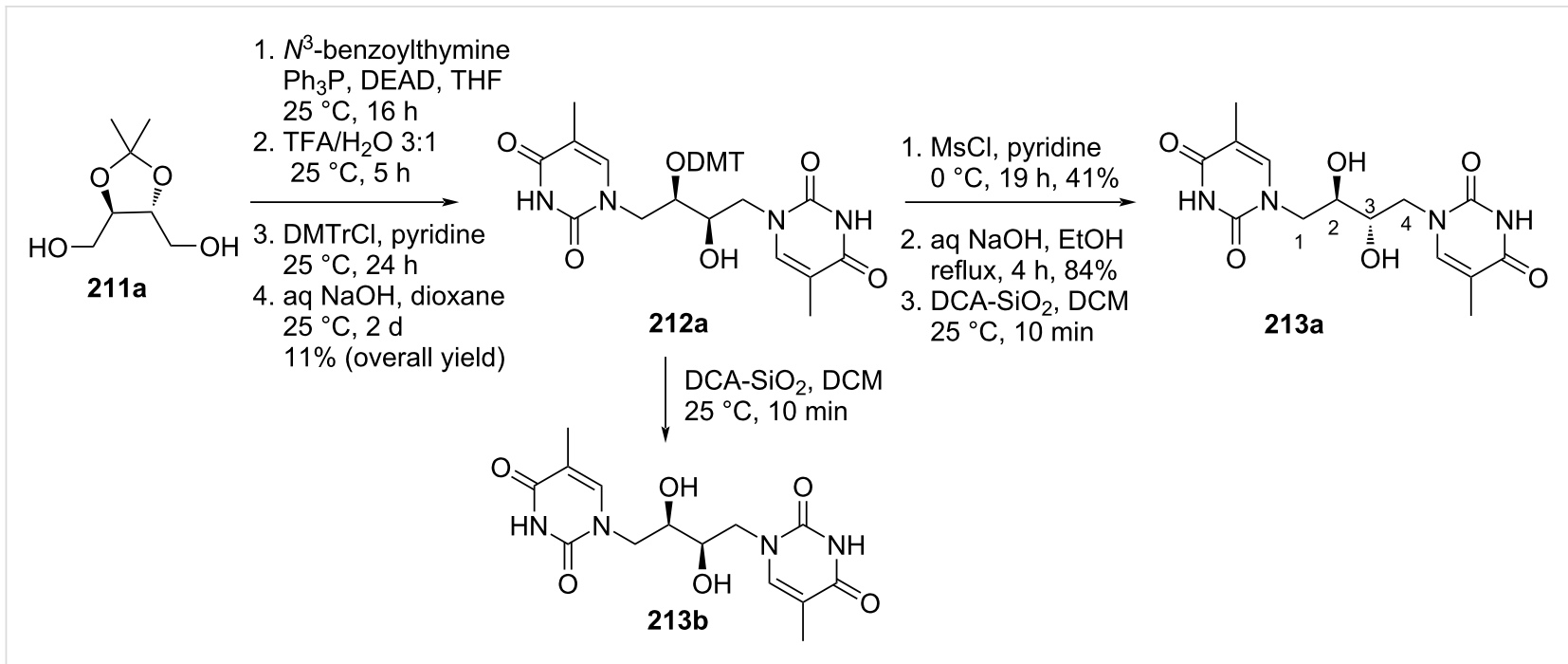

Scheme 56: Synthesis of double-headed acyclic nucleosides $(2 S, 3 R)$-1,4-bis(thymine-1-yl)butane-2,3-diol (213a) and (2R,3R)-1,4-bis(thymine-1yl)butane-2,3-diol (213b).

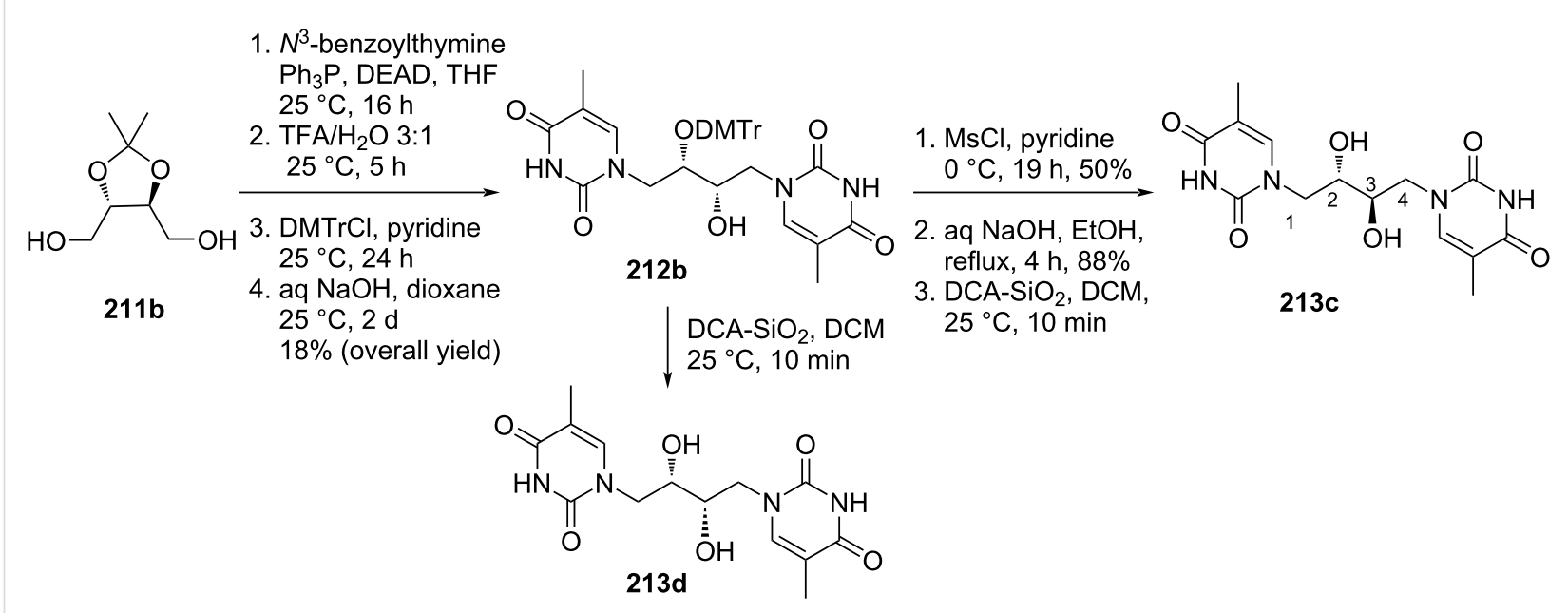

Scheme 57: Synthesis of double-headed acyclic nucleosides (2R,3S)-1,4-bis(thymine-1-yl)butane-2,3-diol (213c) and (2S,3S)-1,4-bis(thymine-1yl)butane-2,3-diol (213d).

acid bishydrazide to give compounds 216a-c which upon acetylation followed by heterocyclization in the presence of thionyl chloride afforded nucleosides $\mathbf{2 1 8 b}-\mathbf{d}$ (Scheme 58) [16].

The synthesized double-headed nucleosides $\mathbf{2 1 8 b}-\mathbf{d}$ may exhibit potential biological activities due to the resistance of the C-glycosidic moiety towards hydrolytic or enzymatic cleavage [90] and the enhanced hydrophilicity which results in an increased transportation to biological systems [16].

El Ashry and co-workers [17] synthesized functionalized 1,2bis(1,2,4-triazol-3-yl)ethane-1,2-diols 222 and 223a-f starting from $(1 R, 2 S)$-1,2-bis(4-amino-5-mercapto-1,2,4-triazol-3-yl)- ethane-1,2-diol (221) which in turn was synthesized by reacting L-tartaric acid (219) with thiocarbohydrazide. The reaction of 4-amino-5-mercapto-3-substituted-1,2,4-triazole 221 with carbon disulfide, ethyl bromoacetate, phenacyl bromide, benzoin, $p$-nitrobenzaldehyde, dimedone, and maleic anhydride afforded the double-headed nucleosides 222 and 223a-f (Scheme 59 and Scheme 60) [17].

The double-headed nucleosides 222 and 223a-f were synthesized with the aim to evaluate their biological activities due to the potent inhibitory effect of the precursor 4-amino-5mercapto-1,2,4-triazole against glycosidase enzymes [17,9193]. 


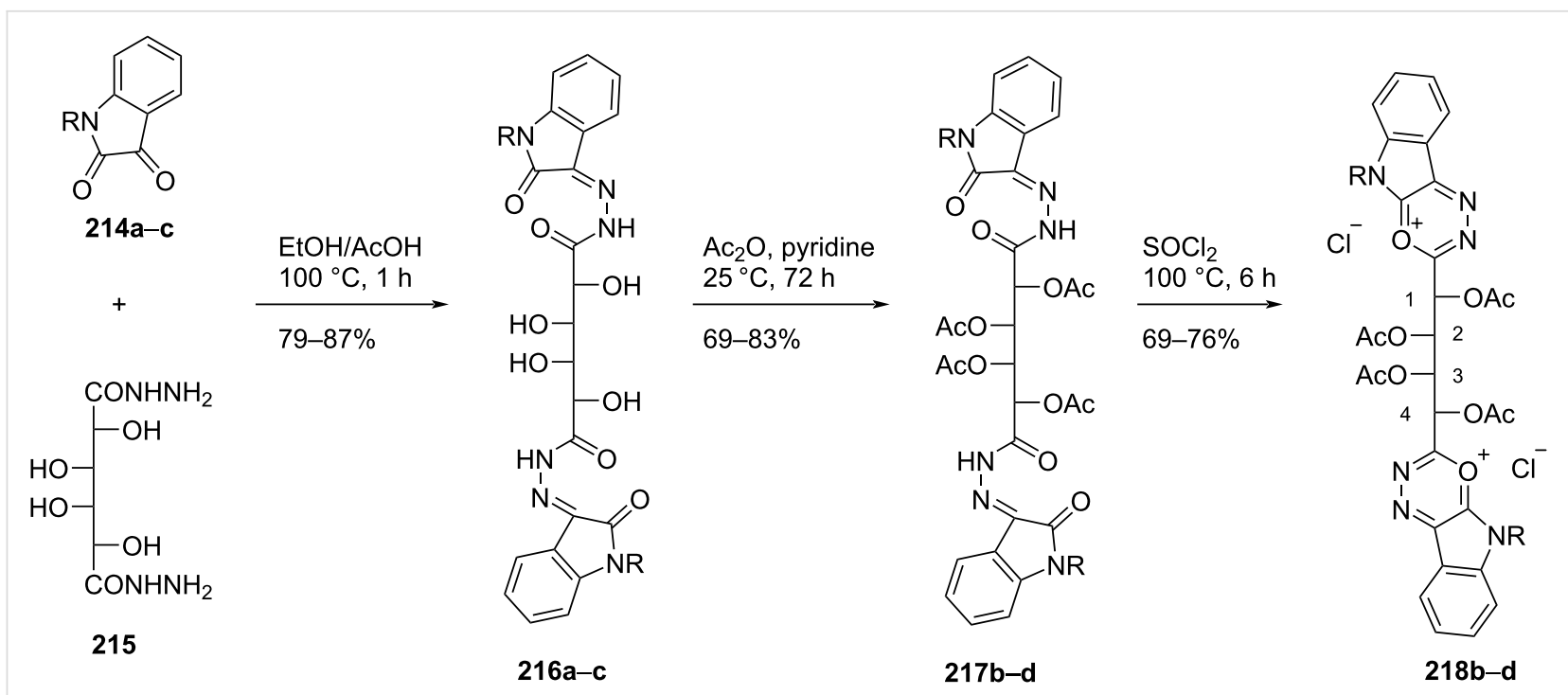

a, $\mathrm{R}=\mathrm{H} ; \mathbf{b}, \mathrm{R}=\mathrm{Me} ; \mathbf{c}, \mathrm{R}=\mathrm{Et} ; \mathbf{d}, \mathrm{R}=\mathrm{Ac}$

Scheme 58: Synthesis of double-headed acetylated 1,3,4-oxadiazino[6,5-b]indolium-substituted C-nucleosides 218b-d

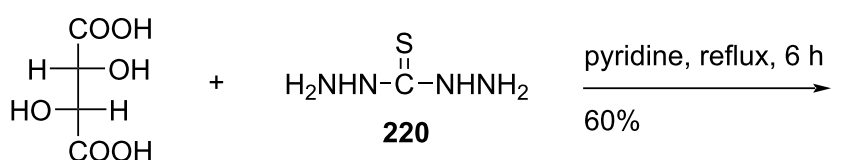

219<smiles>Nn1c(S)nnc1C(O)C(O)c1nnc(S)n1N</smiles>

221

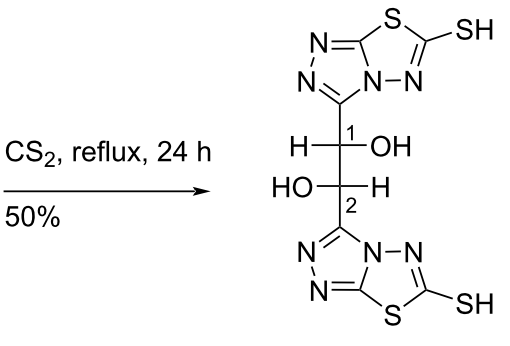

222

Scheme 59: Synthesis of double-headed acyclic nucleoside 222.

Nasr [18] synthesized the double-headed acyclic 1,2,4triazino[5,6- $b$ ]indole $C$-nucleosides 226-231 through the heterocyclization of bis(2-oxoindolin-3-ylidene)galactaric acid hydrazide (225) with various one-nitrogen cyclizing agents (Scheme 61).

The synthesized double-headed nucleosides 226-231 were expected to possess potent biological activities due to the known antimicrobial [94-98], antiviral [99], antihypertensive [99,100], analgesic [101], and antitumor activities [102] exhibited by various derivatives of 1,2,4-triazino[5,6-b]indole [18].

Nasr and co-workers [19] also synthesized double-headed 1,2,4triazoline (232a,b, 233), 1,3,4-oxadiazoline (234), 1,3,4-thiadiazoline (235) acyclo $C$-nucleosides starting from galactaric acid hydrazide (215). The syntheses started with the condensation of compound 215 with carbon disulfide in the presence of ethanolic potassium hydroxide to give the dipotassium salt of galactaric acid bis(hydrazidocarbodithioic acid) which was then heterocyclized under different reaction conditions to give three types of double-headed nucleosides (Scheme 62) [19].

The acyclic double-headed nucleosides 232a and 233-235 were screened for their in vitro antibacterial activity against the Gram-negative bacterium Escherichia coli and the Gram-positive bacterium Staphylococcus aureus and for their antifungal activity against Candida albicans using the agar diffusion method [103]. Among the tested compound, derivative 235 showed fair activity against $E$. coli and $C$. albicans but was inactive against $S$. aureus whereas compound 234 showed activity only against $S$. aureus [19].

Amara and Othman [20] synthesized the double-headed acyclo$C$-nucleosides 1,4-bis(3-mercapto-1H-1,2,4-triazol-5-yl)butane- 


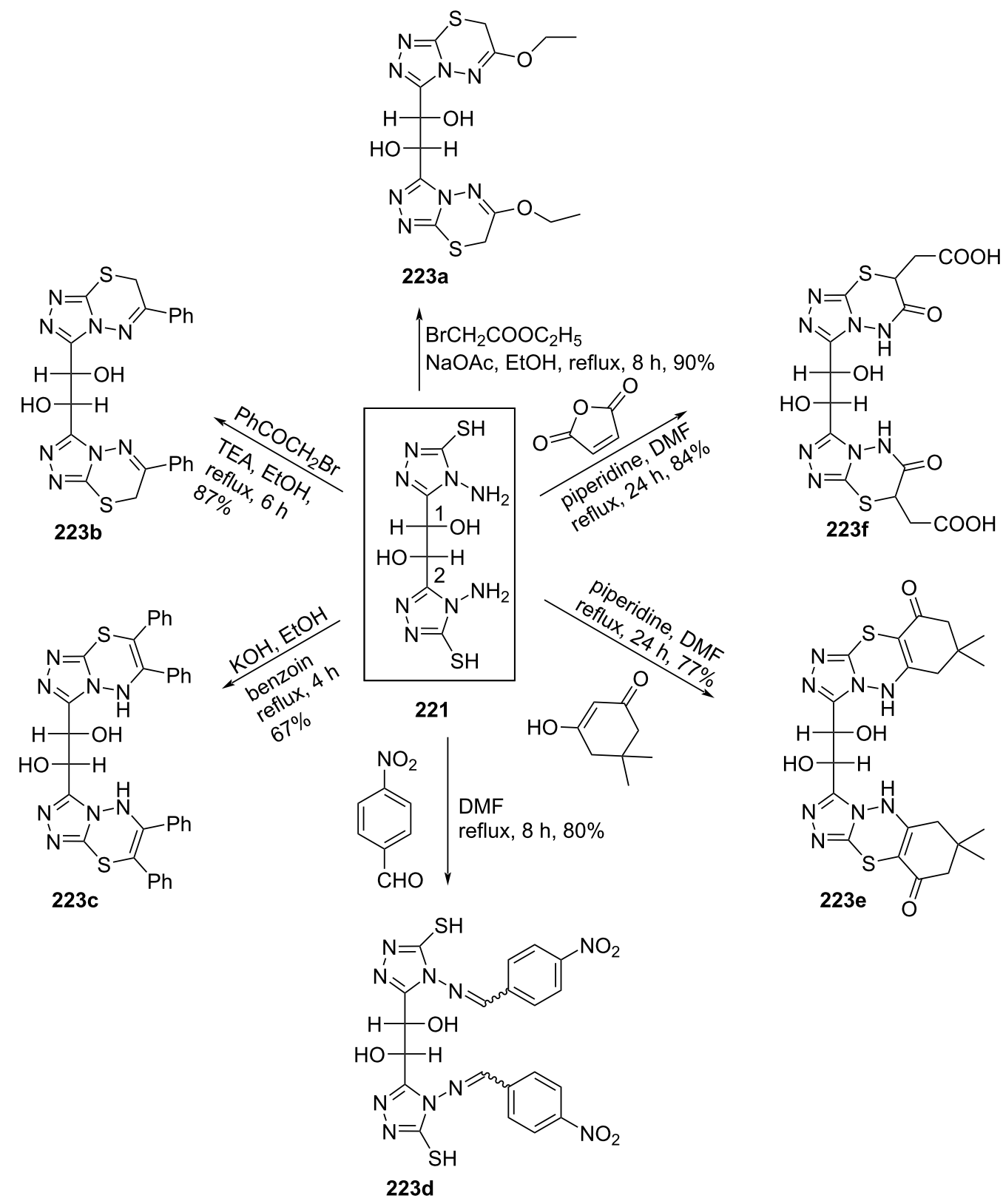

Scheme 60: Synthesis of functionalized 1,2-bis(1,2,4-triazol-3-yl)ethane-1,2-diols 223a-f.

1,2,3,4-tetrol 240, 5,5'-(1,2,3,4-tetrahydroxybutane-1,4-diyl)bis(1,3,4-oxadiazole-2(3H)-thione) $\mathbf{2 4 1}$, and 1,4-bis(4-amino-5mercapto-4H-1,2,4-triazol-3-yl)butane-1,2,3,4-tetrol $\mathbf{2 4 2}$ starting from D-glucose (236). The inexpensive sugar 236 was converted into 2,3,4,5-tetrahydroxyhexanedihydrazide $\mathbf{2 3 8}$ in two steps which was further reacted with either ammonium thiocyanate or carbon disulfide to give the bishydrazinocarbothioamide 239 and the acyclic double-headed nucleoside 241, respectively. The double-headed nucleosides $\mathbf{2 4 0}$ and $\mathbf{2 4 2}$ were obtained by treatment of compound 239 with $\mathrm{NaOH}$ and of compound 241 with hydrazine hydrate, respectively (Scheme 63) [20].

The double-headed $C$-nucleosides 240-242 were tested in vitro against Gram-positive bacteria Staphylococcus aureus, Listeria inovanii and Gram-negative bacteria Klebsiella pneumoniae, Salmonella sp., and Escherichia coli. All the double-headed nucleosides except derivative $\mathbf{2 4 2}$ showed moderate antibacterial activity in comparison with the known antibiotic combination amoxicillin/clavulanic acid (AMC) [20]. 


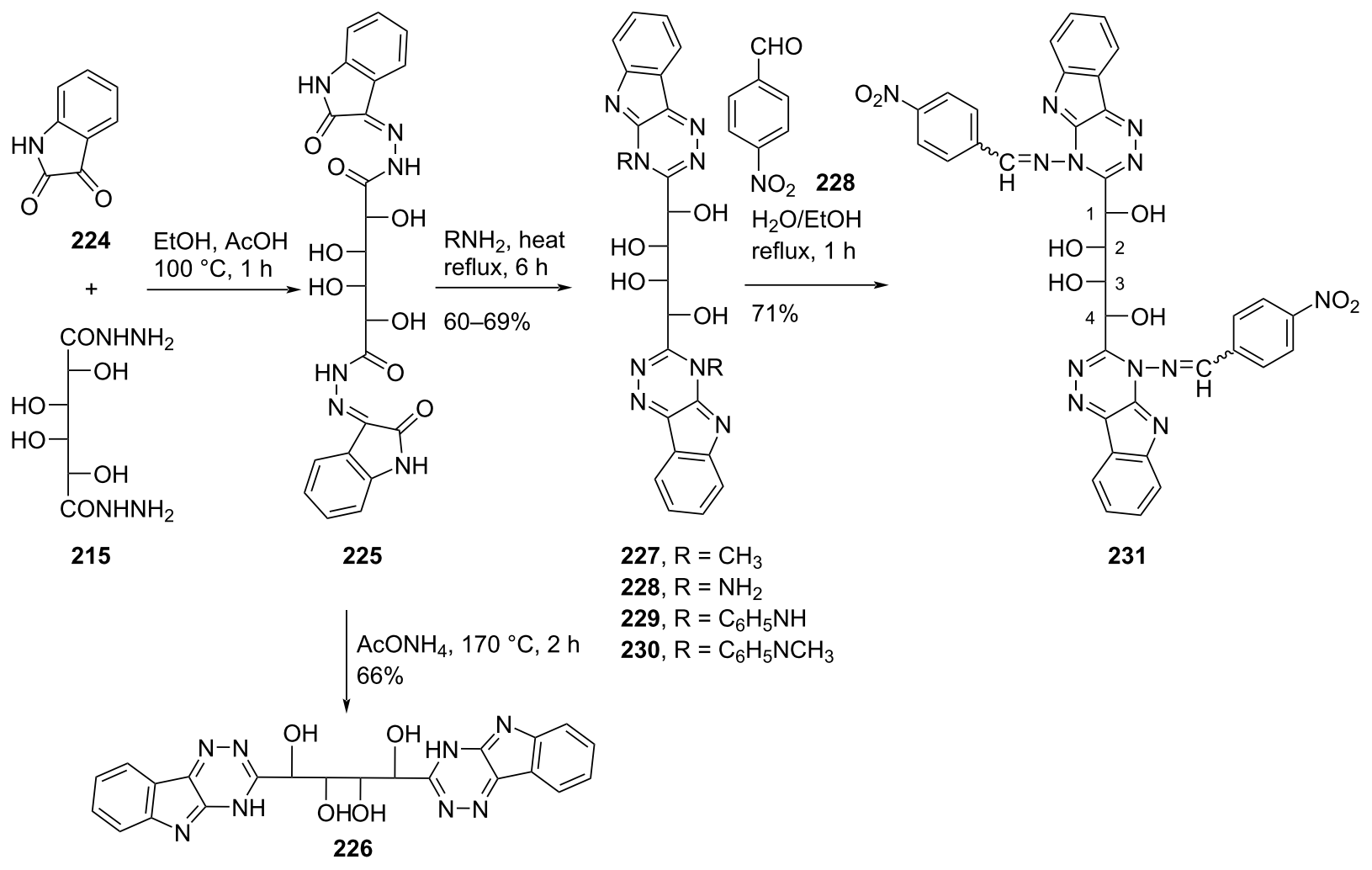

Scheme 61: Synthesis of acyclic double-headed 1,2,4-triazino[5,6-b]indole $C$-nucleosides 226-231.

The structural and electronic properties of the double-headed nucleosides were explored theoretically by performing semiempirical molecular orbital, ab initio Hartree-Fock (HF), and density functional theory (DFT) calculations and their geometries were optimized at the level of Austin Model 1 (AM1) [104].

Galactaric acid (243) was diesterified with ethanol in the presence of conc. sulfuric acid. The corresponding diethyl ester $\mathbf{2 4 4}$ was treated with thiocarbohydrazide in a fusion reaction to produce compound $\mathbf{2 4 5}$, which upon treatment with acetic anhydride under heating conditions, afforded the acyclic doubleheaded acyclic $C$-nucleoside 246 (Scheme 64) [21].

Some 3,6-disubstituted 1,2,4-triazolo[3,4-b]1,3,4-thiadiazole derivatives possess anti-HIV-I [105], anti-inflammatory $[106,107]$, anticancer [108,109], and antibacterial properties [110]. The double-headed $C$-nucleoside $\mathbf{2 4 6}$ comprises an alditolyl moiety attached at position 3 of the 1,2,4-triazolo[3,4b]1,3,4-thiadiazole core which can enhance the biological activity due to the hydrophilic nature of the alditolyl residue which may further increase the transportation into biological systems [21].
Compound 247 was treated with adenine in the presence of sodium hydride in DMF at $105{ }^{\circ} \mathrm{C}$ to incorporate two adenine moieties affording compound $\mathbf{2 4 8}$. The benzoylation of compound 248, followed by treatment with methanolic ammonia at low temperature produced the corresponding $N$-benzoylated adenine derivative $\mathbf{2 4 9}$ [111]. The cleavage of the diacetal in compound 249 was achieved with $75 \%$ TFA/water resulting in compound 250, which was considered as the acyclic doubleheaded nucleoside without any protection of the primary hydroxy groups (Scheme 65) [111].

In a similar reaction sequence, compound $\mathbf{2 5 1}$ was treated with $N^{3}$-benzoylthymine to afford compound $\mathbf{2 5 2}$, which was treated with 75\% TFA-water for deprotection of the hydroxy groups to afford the final monomer 253 (Scheme 66) [111].

The synthesized acyclo nucleosides $\mathbf{2 5 0}$ and $\mathbf{2 5 3}$ were phosphitylated and incorporated into oligonucleotides to evaluate the effects on duplex stability. It was observed that the hybridization properties of the oligonucleotides with one acyclic achiral nucleoside, i.e., $\mathbf{2 5 0}$ or $\mathbf{2 5 3}$ when incorporated in the middle of a 12-mer or 13-mer decreased with complementary DNA or RNA [111]. 
<smiles>OC(c1n[nH]c(=S)[nH]1)C(O)C(O)C(O)c1n[nH]c(=S)[nH]1</smiles>

233<smiles></smiles>

1. $\mathrm{CS}_{2}, \mathrm{KOH}, \mathrm{EtOH}, 25^{\circ} \mathrm{C}, 24 \mathrm{~h}$

2. $\mathrm{RNH}_{2}, \mathrm{a}, \mathrm{R}=\mathrm{Ac}$ : reflux, $1.5 \mathrm{~h}$

$\mathrm{b}, \mathrm{R}=\mathrm{Me}$ : reflux, $6 \mathrm{~h}$

$74-77 \%$ (overall yield)

1. $\mathrm{CS}_{2}, \mathrm{KOH}, \mathrm{EtOH}$ $25{ }^{\circ} \mathrm{C}, 24 \mathrm{~h}$

2. $\mathrm{AcONH}_{4}$, reflux, $1.5 \mathrm{~h}$ $71 \%$ (overall yield)

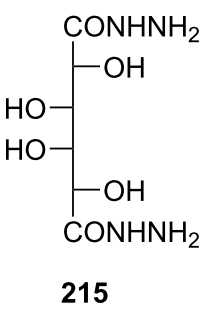

1. $\mathrm{CS}_{2}, \mathrm{KOH}, \mathrm{EtOH}$ $25{ }^{\circ} \mathrm{C}, 24 \mathrm{~h}$

2. $0.1 \mathrm{M} \mathrm{H}_{2} \mathrm{SO}_{4}, \mathrm{MeOH}$ $25^{\circ} \mathrm{C}, 2 \mathrm{~h}$ $82 \%$ (overall yield)

1. $\mathrm{CS}_{2}, \mathrm{KOH}, \mathrm{EtOH}, 25^{\circ} \mathrm{C}, 24 \mathrm{~h}$

2. $\mathrm{KOH}, \mathrm{EtOH}$, reflux, $4 \mathrm{~h}$ $78 \%$ (overall yield)<smiles>OC(c1n[nH]c(=S)o1)C(O)C(O)C(O)c1n[nH]c(=S)o1</smiles>

234

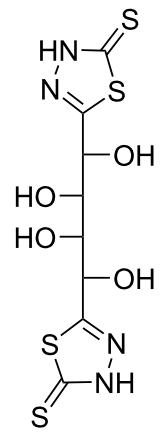

235

Scheme 62: Synthesis of double-headed 1,3,4-thiadiazoline, 1,3,4-oxadiazoline, and 1,2,4-triazoline acyclo $C$-nucleosides 232a,b and 233-235

Four pyrimidine nucleobases 254a-d were treated with methyl iodide in the presence of sodium hydroxide to get methylthio derivatives 255a-d, which were treated with 2,2bis(bromomethyl)-1,3-diacetoxypropane (256) in the presence of $\mathrm{NaH}$ in DMF to afford the mono-headed acyclic nucleosides 257a-d [112]. The second nucleobase was introduced in compounds $257 \mathbf{a}-\mathbf{d}$ by repeating the reaction with the desired nucleobase under otherwise identical conditions (NaH/DMF) giving the acyclic double-headed pyrimidine nucleosides 258a-d. Finally, the treatment of compounds $258 \mathbf{a}-\mathbf{d}$ with
$\mathrm{NaOMe}$ in methanol produced the unprotected nucleosides 259a-d (Scheme 67) [112].

The double-headed nucleoside $\mathbf{2 6 1}$ was obtained by a two-step reaction sequence starting from compound $\mathbf{2 5 6}$, which was first reacted with theophylline in DMF, to give the acyclic doubleheaded purine nucleoside $\mathbf{2 6 0}$ followed by treatment with $\mathrm{NaOMe}$ in methanol to get the unprotected product 261. In the sequence, all reactions were carried out under microwave irradiation conditions (Scheme 68) [112]. 


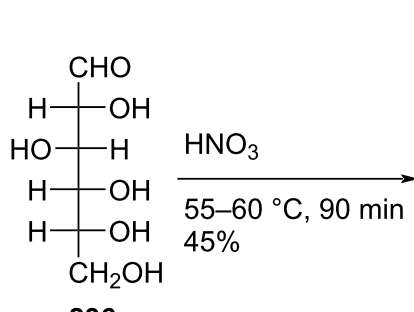

236

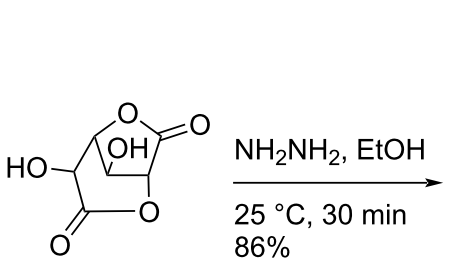

237

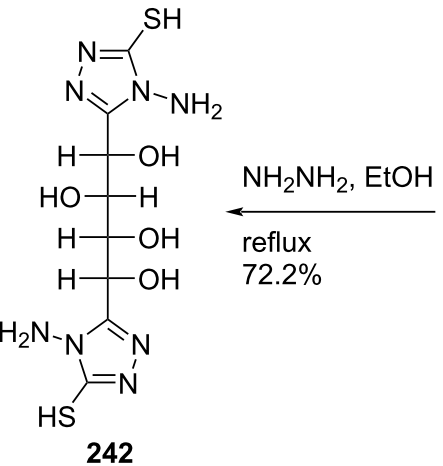

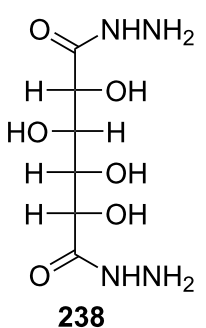

$\mathrm{NH}_{4} \mathrm{SCN}, \mathrm{HCl}$

$\mathrm{H}_{2} \mathrm{O}$, reflux, $8 \mathrm{~h}$ $88.6 \%$

$\mathrm{CS}_{2}, \mathrm{NaOH}$,

$\mathrm{H}_{2} \mathrm{O}$, reflux, $8 \mathrm{~h}$ $76.3 \%$

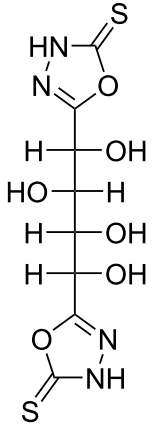

241

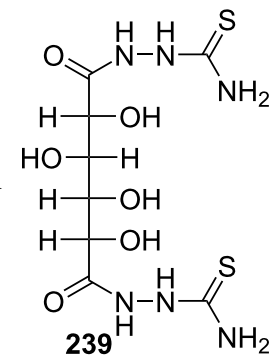

$\mathrm{NaOH}, \mathrm{EtOH}$ $25^{\circ} \mathrm{C}, 30 \mathrm{~min}$ $84.4 \%$

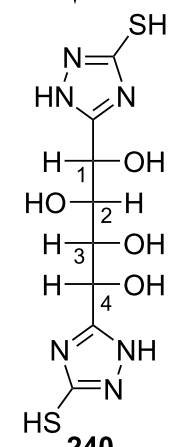

240

Scheme 63: Synthesis of double-headed acyclo $C$-nucleosides 240-242.

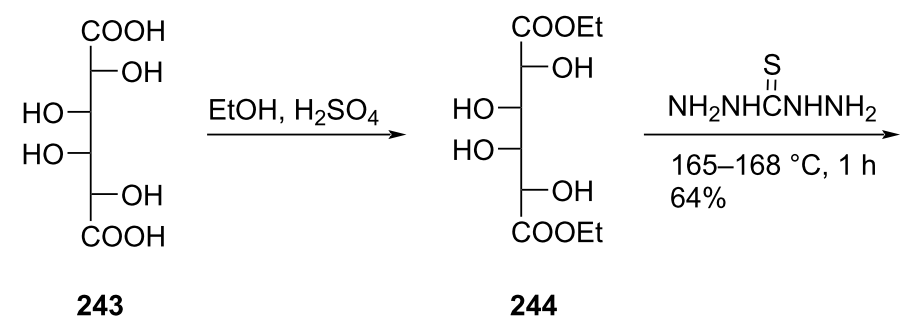

243

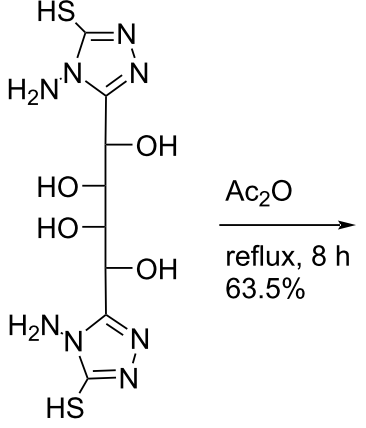

245

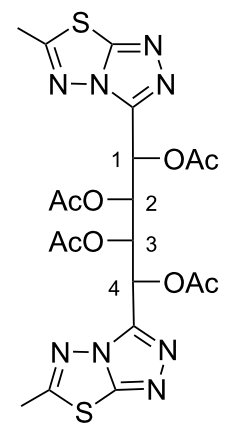

246

Scheme 64: Synthesis of double-headed acyclo $C$-nucleoside 246.

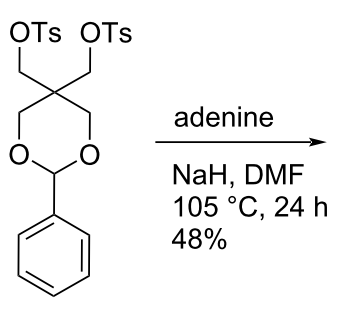

247<smiles>CCC1COC(c2ccccc2)OC1</smiles>

248

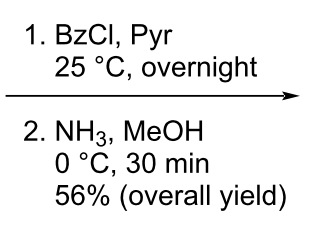

$56 \%$ (overall yield)

249

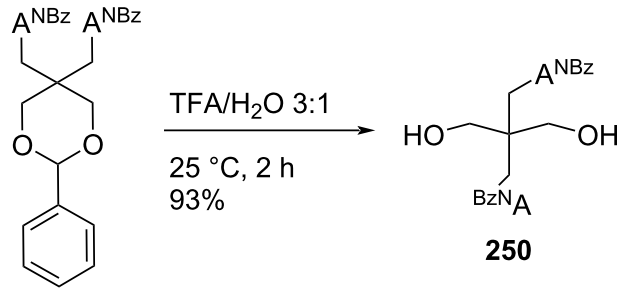

$\mathrm{A}^{\mathrm{NBz}}=$<smiles>Cn1cnc2c(N)cccc21</smiles>

Scheme 65: Synthesis of acyclo double-headed nucleoside 250 


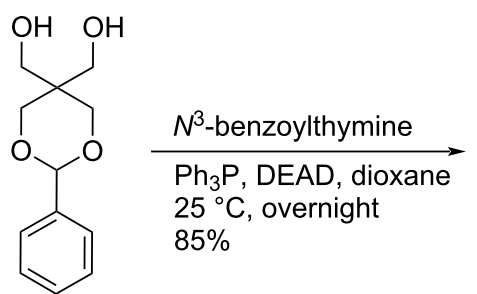

251

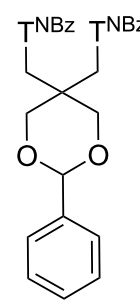

252

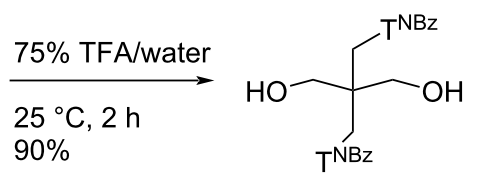

253<smiles>Cc1cn(C)c(=O)n(C(=O)c2ccccc2)c1=O</smiles>

Scheme 66: Synthesis of acyclo double-headed nucleoside 253.<smiles>[R16]c1[nH]c(S)nc(=O)c1[R16]</smiles>

$\mathrm{NaOMe}, \mathrm{MeOH}$

$25^{\circ} \mathrm{C}, 2 \mathrm{~h}$

$87-96 \%$<smiles></smiles>

1. $\mathrm{NaH}, \mathrm{DMF}$

$\mathrm{MW}, 10 \mathrm{~min}$<smiles>CC(=O)OCC(C)(CBr)COC(C)=O</smiles>

256

MW, 10 min

35-61\%

(overall yield)<smiles>[R]c1c([R])n(CC(CBr)(COC(C)=O)COC(C)=O)c(S(C)(=O)=O)nc1=O</smiles>

$\mathrm{NaH}, \mathrm{DMF}$ 254a-d

$\mathrm{MW}, 10 \mathrm{~min}$

22-26\%

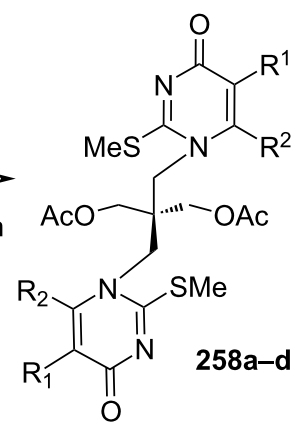

Scheme 67: Synthesis of acyclo double-headed nucleosides $259 a-d$.<smiles>CC(=O)OCC(CBr)(CBr)CO[13C](=O)[O-]</smiles>

Scheme 68: Synthesis of acyclo double-headed nucleoside 261.

The branched chain tetraseco-nucleosides 259a-d and 261 were synthesized because acyclic nucleosides of tetraseco-type were found to possess interesting antiviral activities [21,113-115].

\section{Conclusion}

Among the variety of modified nucleosides, double-headed nucleoside monomers are an important class of compounds, 
which have shown their importance in nucleoside chemistry. Here, we have focused on the available methodologies for the synthesis of several double-headed nucleosides. For a systematic discussion, we have classified them into three different categories, i.e., double-headed nucleosides with additional head/ nucleobase on the sugar moieties, nucleobase moieties and on acyclic carbohydrate moieties. We have subdivided the category of monocyclic furanosyl double-headed nucleosides into 1,2-furanosyl-, 1,3-furanosyl-, 1,4-furanosyl-, and 1,5-furanosyl double-headed nucleosides depending on the position of the aglycon moiety in the furanosyl ring and systematically described their synthetic methodologies. Next, we elaborated the procedures for the synthesis of bicyclic furanosyl doubleheaded nucleosides, followed by procedures for the development of base to base double-headed nucleosides. The chemical strategies for the synthesis of pyranosyl double-headed nucleosides and acyclic double-headed nucleosides were also described. Along with the methodologies for the development of double-headed nucleoside monomers, the synthetic approach for their incorporation into the oligonucleotides was also elaborated in this review. Biological applications of the synthesized nucleosides were also described.

\section{Future Direction}

Double-headed nucleosides are important structural scaffolds that modulate nucleic acid structures. Rationally designed nucleosides can tune interstrand and intrastrand interactions that are exhibited in nucleic acids. As a consequence, these synthetic scaffolds can be exploited rationally in biomolecular designs and medicinal chemistry. These modified double-headed nucleosides could be incorporated into oligonucleotides to explore their potential as antisense nucleosides. Similarly, as some of these nucleosides have shown their potential as antimicrobial agents, they could be explored extensively for their biological activity. This review will help researchers to get an insight into the available procedures for the synthesis of doubleheaded nucleosides and briefly explores their role in modulating nucleic acid structures and in medicinal chemistry. The researchers working in the field of modified nucleosides will be encouraged further to take up challenges for the synthesis of currently unexplored double-headed nucleosides with extensive configurations, connectivity through different linkers, and exploration of different purine and pyrimidine moieties as nucleobases.

\section{Funding}

We are grateful to the Institute of Eminence, University of Delhi for providing financial support under R\&D program. V.V. and V.K.M. thank CSIR, New Delhi and CFEES (DRDO), New Delhi, respectively for the award of Junior/Senior Research Fellowships.

\section{ORCID ${ }^{\circledR}$ iDs}

Himal K. Ganguly - https://orcid.org/0000-0001-6142-4155

\section{References}

1. Blackburn, G. M.; Gait, M. J.; Loakes, D.; Williams, D. M., Eds. Nucleic Acids in Chemistry and Biology, 3rd ed.; Royal Society of Chemistry: Cambridge, UK, 2006. doi:10.1039/9781847555380

2. Neidle, S. Principles of Nucleic Acid Structure; Elsevier: Amsterdam, Netherlands, 2008. doi:10.1016/b978-0-12-369507-9.x5001-8

3. Herdewijn, P., Ed. Modified Nucleosides: in Biochemistry, Biotechnology and Medicine; Wiley-VCH: Weinheim, Germany, 2008. doi:10.1002/9783527623112

4. Simons, C. Nucleoside Mimetics: Their Chemistry and Biological Properties; CRC Press: Boca Raton, FL, USA, 2000. doi:10.1201/9781482283143

5. Mangla, P.; Maity, J.; Rungta, P.; Verma, V.; Sanghvi, Y. S.; Prasad, A. K. ChemistrySelect 2019, 4, 3241-3246. doi:10.1002/slct.201900809

6. Ichikawa, E.; Kato, K. Curr. Med. Chem. 2001, 8, 385-423. doi:10.2174/0929867013373471

7. McKenzie, L. K.; El-Khoury, R.; Thorpe, J. D.; Damha, M. J.; Hollenstein, M. Chem. Soc. Rev. 2021, 50, 5126-5164. doi:10.1039/d0cs01430c

8. Jahnz-Wechmann, Z.; Framski, G. R.; Januszczyk, P. A.; Boryski, J. Front. Chem. (Lausanne, Switz.) 2016, 4, No. 19. doi:10.3389/fchem.2016.00019

9. Townsend, L. B. Chemistry of Nucleosides and Nucleotides; Springer Science + Business Media: New York, NY, USA, 1994; Vol. 3. doi:10.1007/978-1-4757-9667-4

10. Lamberth, C. Org. Prep. Proced. Int. 2002, 34, 149-167. doi:10.1080/00304940209355752

11. Zhang, X.; Amer, A.; Fan, X.; Balzarini, J.; Neyts, J.; De Clercq, E.; Prichard, M.; Kern, E.; Torrence, P. F. Bioorg. Chem. 2007, 35, 221-232. doi:10.1016/j.bioorg.2006.11.003

12. Timoshchuk, V. A.; Hogrefe, R. I. Nucleosides, Nucleotides Nucleic Acids 2009, 28, 464-472. doi:10.1080/15257770903044598

13. Horton, D.; Tsai, J.-H. Carbohydr. Res. 1979, 75, 141-150. doi:10.1016/s0008-6215(00)84634-0

14. Shaikh, K. I.; Madsen, C. S.; Nielsen, L. J.; Jørgensen, A. S.; Nielsen, H.; Petersen, M.; Nielsen, P. Chem. - Eur. J. 2010, 16, 12904-12919. doi:10.1002/chem.201001253

15. Kočalka, P.; Andersen, N. K.; Jensen, F.; Nielsen, P. ChemBioChem 2007, 8, 2106-2116. doi:10.1002/cbic.200700410

16. Nasr, A. Z. Nucleosides, Nucleotides Nucleic Acids 2004, 23, 1825-1832. doi:10.1081/ncn-200040617

17. Moustafa, A. H.; Haggam, R. A.; Younes, M. E.; El Ashry, E. S. H. Nucleosides, Nucleotides Nucleic Acids 2005, 24, 1885-1894. doi:10.1080/15257770500268962

18. Nasr, A. Z. J. Chin. Chem. Soc. 2005, 52, 519-524. doi:10.1002/jccs.200500075

19. Nasr, A. Z.; Mostafa, M. A. Phosphorus, Sulfur Silicon Relat. Elem. 2005, 180, 1769-1779. doi:10.1080/104265090888397

20. Amara, S.; Othman, A. A. Arabian J. Chem. 2016, 9, S1840-S1846. doi:10.1016/j.arabjc.2012.05.005

21. Awad, L. F.; El Ashry, E. S. H. Carbohydr. Res. 1998, 312, 9-22. doi:10.1016/s0008-6215(98)00205-5

22. Hornum, M.; Kumar, P.; Podsiadly, P.; Nielsen, P. J. Org. Chem. 2015, 80, 9592-9602. doi:10.1021/acs.joc.5b01577 
23. Kumar, P.; Sharma, P. K.; Nielsen, P. Bioorg. Med. Chem. 2017, 25, 2084-2090. doi:10.1016/j.bmc.2017.02.011

24. Kumar, P.; Østergaard, M. E.; Baral, B.; Anderson, B. A.; Guenther, D. C.; Kaura, M.; Raible, D. J.; Sharma, P. K.; Hrdlicka, P. J. J. Org. Chem. 2014, 79, 5047-5061. doi:10.1021/j0500614a

25. Østergaard, M. E.; Guenther, D. C.; Kumar, P.; Baral, B.; Deobald, L.; Paszczynski, A. J.; Sharma, P. K.; Hrdlicka, P. J. Chem. Commun. 2010, 46, 4929-4931. doi:10.1039/c0cc01133a

26. Andersen, N. K.; Chandak, N.; Brulíková, L.; Kumar, P.; Jensen, M. D.; Jensen, F.; Sharma, P. K.; Nielsen, P. Bioorg. Med. Chem. 2010, 18, 4702-4710. doi:10.1016/j.bmc.2010.05.019

27. Kumar, P.; Chandak, N.; Nielsen, P.; Sharma, P. K. Bioorg. Med. Chem. 2012, 20, 3843-3849. doi:10.1016/j.bmc.2012.04.036

28. Kumar, P.; Chandak, N.; Nielsen, P.; Sharma, P. K. Trends Carbohydr. Res. 2016, 8, 9-14.

29. Sharma, P. K.; Kumar, P.; Nielsen, P. Aust. J. Chem. 2016, 69, 1094-1101. doi:10.1071/ch16021

30. Andersen, C.; Sharma, P. K.; Christensen, M. S.; Steffansen, S. I.; Madsen, C. M.; Nielsen, P. Org. Biomol. Chem. 2008, 6, 3983-3988. doi:10.1039/b810930c

31. Christensen, M. S.; Madsen, C. M.; Nielsen, P. Org. Biomol. Chem. 2007, 5, 1586-1594. doi:10.1039/b700852j

32. Hornum, M.; Sharma, P. K.; Reslow-Jacobsen, C.; Kumar, P.; Petersen, M.; Nielsen, P. Chem. Commun. 2017, 53, 9717-9720. doi:10.1039/c7cc05047j

33. Madsen, C. S.; Witzke, S.; Kumar, P.; Negi, K.; Sharma, P. K.; Petersen, M.; Nielsen, P. Chem. - Eur. J. 2012, 18, 7434-7442. doi:10.1002/chem.201103467

34. Kumar, P.; Sharma, P. K.; Madsen, C. S.; Petersen, M.; Nielsen, P. ChemBioChem 2013, 14, 1072-1074. doi:10.1002/cbic.201300086

35. Pedersen, S. L.; Nielsen, P. Org. Biomol. Chem. 2005, 3, 3570-3575. doi:10.1039/b510167k

36. Chatzileontiadou, D. S. M.; Parmenopoulou, V.; Manta, S.; Kantsadi, A. L.; Kylindri, P.; Griniezaki, M.; Kontopoulou, F.; Telopoulou, A.; Prokova, H.; Panagopoulos, D.; Boix, E.; Balatsos, N. A. A.; Komiotis, D.; Leonidas, D. D. Bioorg. Chem. 2015, 63, 152-165. doi:10.1016/j.bioorg.2015.10.007

37. Kiritsis, C.; Manta, S.; Papasotiriou, I.; Coutouli-Argyropoulou, E.; Trakossas, S.; Balzarini, J.; Komiotis, D. Med. Chem. 2012, 8 , 320-329. doi:10.2174/157340612800786624

38. Kumar, P.; Sharma, P. K.; Nielsen, P. J. Org. Chem. 2014, 79, 11534-11540. doi:10.1021/j0502189h

39. Hornum, M.; Stendevad, J.; Sharma, P. K.; Kumar, P.; Nielsen, R. B.; Petersen, M.; Nielsen, P. Chem. - Eur. J. 2019, 25, 7387-7395. doi:10.1002/chem.201901077

40. Lemaire, S.; Houpis, I.; Wechselberger, R.; Langens, J.; Vermeulen, W. A. A.; Smets, N.; Nettekoven, U.; Wang, Y.; Xiao, T.; Qu, H.; Liu, R.; Jonckers, T. H. M.; Raboisson, P.; Vandyck, K.; Nilsson, K. M.; Farina, V. J. Org. Chem. 2011, 76, 297-300. doi:10.1021/jo101822j

41. Corey, E. J.; Chaykovsky, M. J. Am. Chem. Soc. 1965, 87, 1353-1364. doi:10.1021/ja01084a034

42. Beck, K.; Reslow-Jacobsen, C.; Hornum, M.; Henriksen, C.; Nielsen, P. Bioorg. Med. Chem. Lett. 2019, 29, 740-743. doi:10.1016/j.bmcl.2019.01.002
43. Jorgensen, A. S.; Shaikh, K. I.; Enderlin, G.; Ivarsen, E.; Kumar, S.; Nielsen, P. Org. Biomol. Chem. 2011, 9, 1381-1388. doi:10.1039/c0ob00438c

44. Kirschenheuter, G. P.; Zhai, Y.; Pieken, W. A. Tetrahedron Lett. 1994, 35, 8517-8520. doi:10.1016/s0040-4039(00)78425-5

45. Kumar, P.; Madsen, C. S.; Nielsen, P. Bioorg. Med. Chem. Lett. 2013, 23, 6847-6850. doi:10.1016/j.bmcl.2013.10.006

46. Cieślak, J.; Grajkowski, A.; Ausín, C.; Gapeev, A.; Beaucage, S. L. Nucleic Acids Res. 2012, 40, 2312-2329. doi:10.1093/nar/gkr896

47. Costa, A. M.; Faja, M.; Farràs, J.; Vilarrasa, J. Tetrahedron Lett. 1998, 39, 1835-1838. doi:10.1016/s0040-4039(98)00100-2

48. Li, N.-S.; Piccirilli, J. A. J. Org. Chem. 2004, 69, 4751-4759. doi:10.1021/j00495337

49. Sano, T.; Shuto, S.; Inoue, H.; Ueda, T. Chem. Pharm. Bull. 1985, 33, 3617-3662. doi:10.1248/cpb.33.3617

50. Gao, Z.-G.; Duong, H. T.; Sonina, T.; Kim, S.-K.; Van Rompaey, P.; Van Calenbergh, S.; Mamedova, L.; Kim, H. O.; Kim, M. J.; Kim, A. Y. Liang, B. T.; Jeong, L. S.; Jacobson, K. A. J. Med. Chem. 2006, 49, 2689-2702. doi:10.1021/jm050968b

51. Lazrek, H. B.; Taourirte, M.; Oulih, T.; Kabbaj, Y.; Barascut, J. L.; Imbach, J. L.; Almasoudi, N. A.; Pfleiderer, W. Nucleosides Nucleotides 1997, 16, 1073-1077. doi:10.1080/07328319708006135

52. Horwitz, J. P.; Chua, J.; Noel, M. J. Org. Chem. 1964, 29, 2076-2078. doi:10.1021/j001030a546

53. Epp, J. B.; Widlanski, T. S. J. Org. Chem. 1999, 64, 293-295. doi:10.1021/jo981316g

54. Wu, T.; Nauwelaerts, K.; Van Aerschot, A.; Froeyen, M.; Lescrinier, E.; Herdewijn, P. J. Org. Chem. 2006, 71, 5423-5431. doi:10.1021/jo052194c

55. O-Yang, C.; Wu, H. Y.; Fraser-Smith, E. B.; Walker, K. A. M. Tetrahedron Lett. 1992, 33, 37-40. doi:10.1016/s0040-4039(00)77667-2

56. Jones, G. H.; Taniguchi, M.; Tegg, D.; Moffatt, J. G. J. Org. Chem. 1979, 44, 1309-1317. doi:10.1021/jo01322a025

57. Fecher, R.; Boswell, K. H.; Wittick, J. J.; Shen, T. Y. J. Am. Chem. Soc. 1970, 92, 1400-1402. doi:10.1021/ja00708a051

58. Fecher, R.; Boswell, K. H.; Wittick, J. J.; Shen, T. Y. Carbohydr. Res. 1970, 13, 105-111. doi:10.1016/s0008-6215(00)84900-9

59. Kašnar, B.; Škarić, V.; Klaić, B.; Žinić, M. Tetrahedron Lett. 1993, 34, 4997-5000. doi:10.1016/s0040-4039(00)74067-6

60. Montgomery, J. A.; Hewson, K. In Synthetic Procedures in Nucleic Acid Chemistry; Zorbach, W. W.; Tipson, R. S., Eds.; Interscience Publishers, John Wiley \& Sons Ltd.: London-New York, 1968; Vol. 1, pp 180-182.

61. Baker, J. J.; Mellish, P.; Riddle, C.; Somerville, A. R.; Tittensor, J. R. J. Med. Chem. 1974, 17, 764-766. doi:10.1021/jm00253a027

62. Wang, G.; Middleton, P. J. Tetrahedron Lett. 1996, 37, 2739-2742. doi:10.1016/0040-4039(96)00418-2

63. Sharma, P. K.; Mikkelsen, B. H.; Christensen, M. S.; Nielsen, K. E.; Kirchhoff, C.; Pedersen, S. L.; Sørensen, A. M.; Østergaard, K.; Petersen, M.; Nielsen, P. Org. Biomol. Chem. 2006, 4, 2433-2445. doi:10.1039/b603830a

64. Borsting, P.; Nielsen, K. E.; Nielsen, P. Org. Biomol. Chem. 2005, 3, 2183-2190. doi:10.1039/b502720a

65. Andersen, C.; Sharma, P. K.; Christensen, M. S.; Pedersen, N. S.; Nielsen, P. Nucleic Acids Symp. Ser. 2008, 52, 275-276. doi:10.1093/nass/nrn139

66. Fensholdt, J.; Wengel, J. Acta Chem. Scand. 1996, 50, 1157-1163. 
67. Kumar, S.; Steffansen, S. I.; Albæk, N.; Nielsen, P. Tetrahedron 2014, 70, 583-589. doi:10.1016/j.tet.2013.12.013

68. Albæk, N.; Petersen, M.; Nielsen, P. J. Org. Chem. 2006, 71, 7731-7740. doi:10.1021/jo061225g

69. Umemoto, T.; Wengel, J.; Madsen, A. S. Org. Biomol. Chem. 2009, 7 , 1793-1797. doi:10.1039/b901028a

70. Enderlin, G.; Nielsen, P. J. Org. Chem. 2008, 73, 6891-6894. doi:10.1021/jo801081t

71. Kumar, P.; Sharma, P. K.; Hansen, J.; Jedinak, L.; Reslow-Jacobsen, C.; Hornum, M.; Nielsen, P. Bioorg. Med. Chem. 2016, 24, 742-749. doi:10.1016/j.bmc.2015.12.043

72. Kumar, P.; Sorinas, A. F.; Nielsen, L. J.; Slot, M.; Skytte, K.; Nielsen, A. S.; Jensen, M. D.; Sharma, P. K.; Vester, B.; Petersen, M.; Nielsen, P. J. Org. Chem. 2014, 79, 8020-8030. doi:10.1021/j0501151w

73. Dalager, M.; Andersen, N. K.; Kumar, P.; Nielsen, P.; Sharma, P. K. Org. Biomol. Chem. 2015, 13, 7040-7049. doi:10.1039/c5ob00872g

74. Jacobsen, M. F.; Andersen, C. S.; Knudsen, M. M.; Gothelf, K. V. Org. Lett. 2007, 9, 2851-2854. doi:10.1021/ol071006x

75. Jacobsen, M. F.; Knudsen, M. M.; Gothelf, K. V. J. Org. Chem. 2006, 71, 9183-9190. doi:10.1021/jo061694i

76. Kumar, P.; Østergaard, M. E.; Hrdlicka, P. J. Curr. Protoc. Nucleic Acid Chem. 2011, 4.43.1-4.43.22. doi:10.1002/0471142700.nc0443s44

77. Robins, M. J.; Barr, P. J. J. Org. Chem. 1983, 48, 1854-1862. doi:10.1021/jo00159a012

78. Graham, D.; Parkinson, J. A.; Brown, T. J. Chem. Soc., Perkin Trans. 1 1998, 1131-1138. doi:10.1039/a707031d

79. Hurley, D. J.; Seaman, S. E.; Mazura, J. C.; Tor, Y. Org. Lett. 2002, 4, 2305-2308. doi:10.1021/ol026043x

80. Le, B. T.; Hornum, M.; Sharma, P. K.; Nielsen, P.; Veedu, R. N. RSC Adv. 2017, 7, 54542-54545. doi:10.1039/c7ra10964d

81. Østergaard, M. E.; Kumar, P.; Nichols, J.; Watt, A.; Sharma, P. K.; Nielsen, P.; Seth, P. P. Nucleic Acid Ther. 2015, 25, 266-274. doi:10.1089/nat.2015.0547

82. Goubet, A.; Chardon, A.; Kumar, P.; Sharma, P. K.; Veedu, R. N. Bioorg. Med. Chem. Lett. 2013, 23, 761-763. doi:10.1016/j.bmcl.2012.11.096

83. Knapp, D. M.; Gillis, E. P.; Burke, M. D. J. Am. Chem. Soc. 2009, 131, 6961-6963. doi:10.1021/ja901416p

84. Browne, D. L.; Harrity, J. P. A. Tetrahedron 2010, 66, 553-568. doi:10.1016/j.tet.2009.10.085

85. Ferrier, R. J.; Tyler, P. C. J. Chem. Soc., Perkin Trans. 11980 , 2767-2773. doi:10.1039/p19800002767

86. Verma, V.; Maikhuri, V. K.; Khatri, V.; Singh, A.; Prasad, A. K. Synth. Commun. 2021, 51, 446-452. doi:10.1080/00397911.2020.1836224

87. Khatri, V.; Kumar, A.; Singh, B.; Malhotra, S.; Prasad, A. K. J. Org. Chem. 2015, 80, 11169-11174. doi:10.1021/acs.joc.5b01933

88. Elhalabi, J.; Rice, K. G. Nucleosides, Nucleotides Nucleic Acids 2004, 23, 195-205. doi:10.1081/ncn-120027828

89. Christensen, M. S.; Bond, A. D.; Nielsen, P. Org. Biomol. Chem. 2008, 6, 81-91. doi:10.1039/b713888a

90. Daves, G. D., Jr. Acta Pharm. Suec. 1987, 24, 275-288.

91. El Ashry, E. S. H.; Rashed, N.; Shobier, A. H. Pharmazie 2000, 55 , 251-262.

92. El Ashry, E. S. H.; Rashed, N.; Shobier, A. H. Pharmazie 2000, 55, 331-348.
93. El Ashry, E. S. H.; Rashed, N.; Shobier, A. H. Pharmazie 2000, 56, 403-415.

94. Joshi, K. C.; Jain, S. K.; Jain, A. K. Curr. Sci. 1982, 51, 346-348.

95. Omar, A.-M. M. E.; Eshba, N. H.; Aboushleib, H. M. J. Heterocycl. Chem. 1986, 23, 1731-1735. doi:10.1002/jhet.5570230626

96. Holla, B. S.; Udupa, K. V. J. Indian Chem. Soc. 1988, 65, 524-525.

97. Abdel-Latif, F. F.; Shaker, R. M.; Mahgoub, S. A.; Badr, M. Z. A J. Heterocycl. Chem. 1989, 26, 769-772. doi:10.1002/jhet.5570260348

98. Shaban, M. A. E.; Nasr, A. Z.; Morgaan, A. E. A. Farmaco 1999, 54, 800-809. doi:10.1016/s0014-827x(99)00107-x

99. Kaminsky, D. Method for Producing Antihypertensive Activity. U.S. Patent US3,752,891, Aug 14, 1973.

100. Monge, A.; Palop, J. A.; Ramirez, C.; Fernandez-Alvarez, E. Acta Farm. Bonaerense 1987, 8, 157-162.

101. Tomchin, A. B.; Ignat'eva, M. A.; Masyuta, G. F. Khim.-Farm. Zh. 1972, 6, 23

102. Eshaba, N. H.; Salama, H. M.; Labouta, I. M.; Omar, A.-M. M. E. Pharmazie 1999, 54, 580-587.

103. Yousef, T.; Tawil, G. G. Pharmazie 1980, 35, 698-701.

104. Amara, S.; Tchouar, N.; Belaidi, S. Int. Lett. Chem., Phys. Astron. 2015, 61, 1-11. doi:10.18052/www.scipress.com/ilcpa.61.1

105.Paolo, F.; Daniele, S.; Franca, S.; Noemi, P. Farmaco 1996, 51 , 659-664.

106. Gupta, R.; Sudan, S.; Kachroo, P. L. Indian J. Chem., Sect. B 1996, 35, 718-720.

107.Gupta, R.; Sudan, S.; Kachroo, P. L. J. Indian Chem. Soc. 1996, 73, $625-626$.

108.Sagredou, S.; Dalezis, P.; Nikoleousakos, N.; Nikolaou, M.; Voura, M.; Almpanakis, K.; Panayiotidis, M. I.; Sarli, V.; Trafalis, D. T. OncoTargets Ther. 2020, 13, 7369-7386. doi:10.2147/ott.s254856

109.Bujji, S.; Edigi, P. K.; Subhashini, N. J. P. J. Heterocycl. Chem. 2020, 57, 3318-3325. doi:10.1002/jhet.4047

110. Holla, B. S.; Shivanada, M. K.; Akberali, P. M.; Baliga, S. S. Farmaco 1996, 51, 785-792.

111.Wu, T.; Froeyen, M.; Schepers, G.; Mullens, K.; Rozenski, J.; Busson, R.; Van Aerschot, A.; Herdewijn, P. Org. Lett. 2004, 6, 51-54 doi:10.1021/ol0360647

112. Ashry, E. S. H. E.; Rashed, N.; Abdel-Rahman, A.; Awad, L. F.; Rasheed, H. A. Nucleosides, Nucleotides Nucleic Acids 2006, 25 , 925-939. doi:10.1080/15257770600793919

113.El Ashry, E. S. H.; Abdel Rahman, A. A. H.; Rashed, N.; Rasheed, H. A. Pharmazie 1999, 54, 893-897.

114. Rashed, N.; Hamid, H. A.; Ramadan, E. S.; El Ashry, E. S. H. Nucleosides Nucleotides 1998, 17, 1373-1384. doi:10.1080/07328319808003476

115. Hamed, A.; Abo-Amaym, E. R.; El Ashry, E. S. H. Nucleosides Nucleotides 1998, 17, 1385-1407. doi:10.1080/07328319808003477 


\section{License and Terms}

This is an Open Access article under the terms of the Creative Commons Attribution License (https://creativecommons.org/licenses/by/4.0). Please note that the reuse, redistribution and reproduction in particular requires that the author(s) and source are credited and that individual graphics may be subject to special legal provisions.

The license is subject to the Beilstein Journal of Organic Chemistry terms and conditions:

(https://www.beilstein-journals.org/bjoc/terms)

The definitive version of this article is the electronic one which can be found at:

https://doi.org/10.3762/bjoc.17.98 